\title{
ATIVIDADE PESQUEIRA NO BRASIL: \\ POLÍTICA E EVOLUÇÃO
}

PATRÍZIA RAGGI ABDALLAH

Economista

Orientador: Prof. Dr. CARLOS JOSÉ CAETANO BACHA

Tese apresentada à Escola Superior de Agricultura "Luiz de Queiroz", Universidade de São Paulo, para obtenção do título de Doutor em Ciências, Área de Concentração: Economia Aplicada

P I R A C I C A B A

Estado de São Paulo - Brasil

Novembro - 1998 
Dados Internacionais de Catalogação na Publicação (CIP) DIVISÃo DE BIBLIOTECA E DOCUMENTAÇÃo - Campus "Luiz de Queiroz"/USP

\author{
Abdallah, Patrizia Raggi \\ Atividade pesqueira no Brasil: politica e evoluçāo / Patrizia Raggi Abdallah. - - \\ Piracicaba, 1998. \\ $137 \mathrm{p}$. \\ Tese (doutorado) - - Escola Superior de Agricultura Luiz de Queiroz, 1998. \\ Bibliografia. \\ 1. Economia aplicada 2. Economia pesqueira 3. Industrialização 4. Pesca 5. \\ Pescado 6. Política pesqueira 7. Recurso natural I. Título
}


À minha mãe, que não poupou esforços para minha formação.

\section{OFEREÇO}

À minha família, em especial ao meu irmão Júnior (in memorian), pela presença constante e admiração. 


\section{AGRADECIMENTOS}

À Fundação Universidade do Rio Grande, especialmente ao Departamento de Ciências Econômicas, Administrativas e Contábeis, pelo amplo apoio para a realização do Curso.

Ao Departamento de Economia e Sociologia Rural (DESR) da Escola Superior de Agricultura "Luiz de Queiroz"/ Universidade de São Paulo (ESALQ/USP), pela oportunidade.

À CAPES, através do Programa de Incentivo à Capacitação de Docentes e Técnicos (PICDT), pelo apoio financeiro.

Ao Professor Carlos José Caetano Bacha, pela valiosa orientação, dedicação e eficiência transmitida ao longo da elaboração da Tese.

Aos Professores do DESR/ESALQ/USP, pelos conhecimentos transmitidos, e em especial a Paulo Fernando Cidade de Araújo e Zilda Paes de Barros Mattos pelas contribuições indispensáveis para a realização deste trabalho.

Aos convidados da Banca Examinadora externos à ESALQ/USP, por terem se disponibilizado a participar da avaliação do trabalho.

Aos Professores Maurinho Luiz dos Santos e Luiz Aurélio Raggi, da Universidade Federal de Viçosa, pelo exemplo de competência, pelos seus ensinamentos e pela amizade.

Aos funcionários do DESR/ESALQ/USP, em especial à Luciane, Maielli, Márcia, Cristiane, Maria Helena, Elenice, Helena, Pedro e Valdeci, pelo apoio e amizade.

Aos colegas do Curso, pela agradável convivência, em especial aos amigos Roberto, Piedade, Montoya, Warly, Silvia, Casimiro, Marina, Parré e Ricardo.

À Susana Molon, que esteve sempre presente, com muita amizade e coleguismo.

E, finalmente, a todas as demais pessoas e instituições que, direta ou indiretamente, colaboraram para a realização deste trabalho. 


\section{SUMÁRIO}

Página

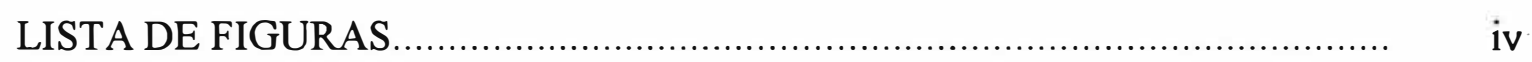

LISTA DE TABELAS ........................................................................

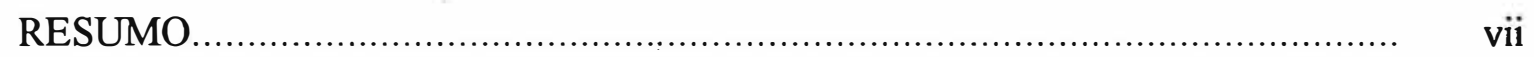

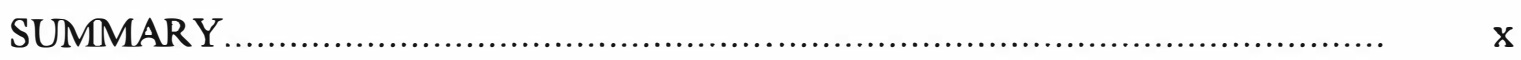

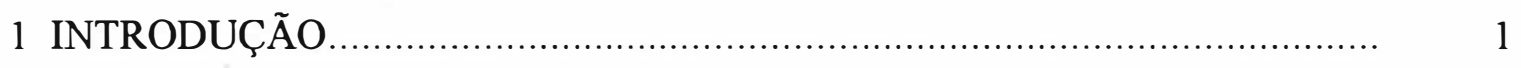

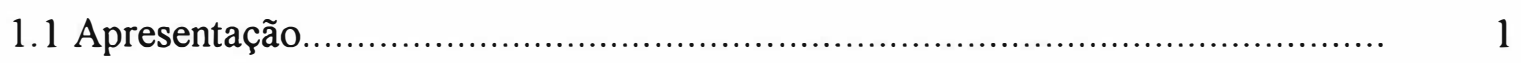

1.2 Revisão de Literatura .................................................................. 4

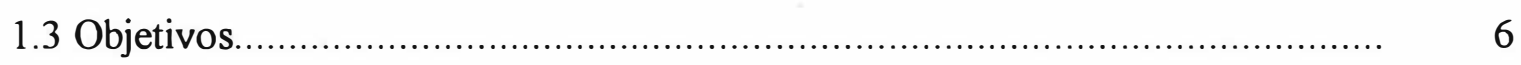

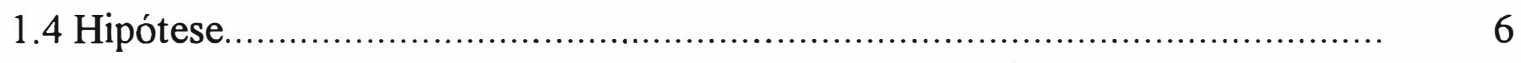

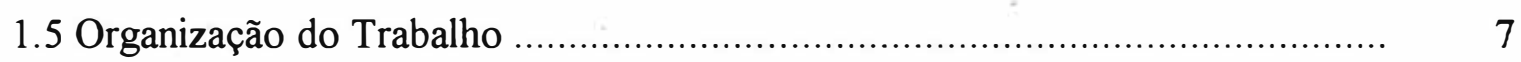

2 REFERENCIAL TEÓRICO E METODOLÓGICO .................................. 8

2.10 pescado como recurso natural renovável, de propriedade comum e de livre

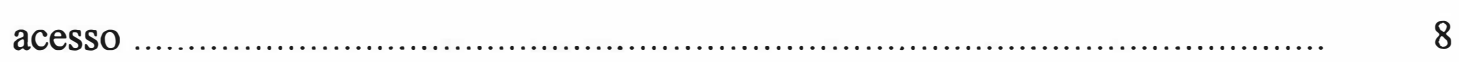

2.1.1 Abordagem bioeconômica dos recursos pesqueiros............................. 10

2.1.2 Modelos de Intervenção do Estado: teorias voltadas para a regulamentação

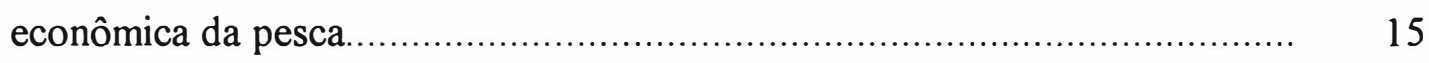

2.2 Aspectos teóricos referentes à análise beneficio-custo e apresentação de um modelo de cálculo do Beneficio Social dos Incentivos Fiscais à atividade da pesca no Brasil....................................................................... 19

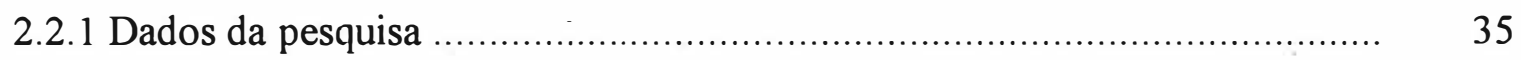


3 AS POLÍTICAS FEDERAIS RELATIVAS À PESCA E A EVOLUÇÃO DA ATIVIDADE PESQUEIRA NO BRASL .................................................... 38

3.1 As políticas pesqueiras nacionais........................................................... 38

3.1.1 Política regulamentadora da atividade pesqueira.......................................... 39

3.1.2 Os incentivos federais à produção pesqueira no Brasil................................ 52

3.1.2.1 Os beneficios fiscais concedidos à atividade pesqueira no Brasil................ 53

3.1.2.2 O FISET/Pesca e sua avaliação pela COMIF .......................................... 55

3.1.2.3 Evolução dos incentivos fiscais concedidos a empreendimentos

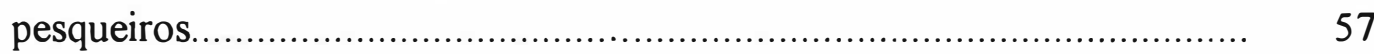

3.2 A evolução da atividade pesqueira no Brasil ................................................ 60

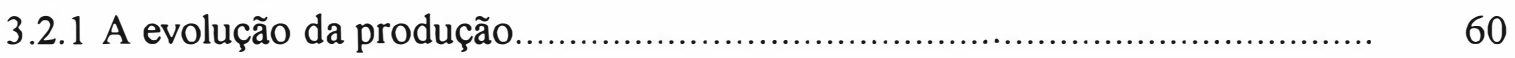

3.2.2 Produção pesqueira marítima versus produção de água doce......................... 63

3.2.3 Análise da produção regional do pescado brasileiro...................................... 69

3.2.4 O consumo aparente do pescado e as transações externas com este produto.

4 ANÁLISE BENEFÍCIO-CUSTO DOS PROGRAMAS FEDERAIS DE INCENTIVOS FISCAIS À PESCA …............................................................. 80

4.1 Estimativa das equações da demanda e da oferta de pescado no Brasil ........... 80

4.2 Cálculo do beneficio e do custo social dos incentivos fiscais concedidos à atividade pesqueira no Brasil.

5 IMPACTOS DO PROGRAMA DE INCENTIVO FISCAL À PESCA SOBRE

O SEGMENTO INDUSTRIAL DO SISTEMA AGROINDUSTRIAL DO PESCADO, SOBRE O VALOR DA PRODUÇÃO PESQUEIRA E NA GERAÇÃO DE EMPREGO .

5.1 A evolução do segmento industrial do Sistema Agroindustrial do Pescado...... 89

5.2 Valor da produção pesqueira ..................................................................... 95

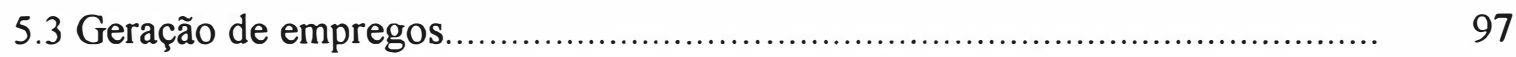


6 CONCLUSÕES

100

REFERÊNCIAS BIBLIOGRÁFICAS.

106

APÊNDICES. 


\section{LISTA DE FIGURAS}

Página

1 Curvas de Receita Total e Custo Total a preços constantes.................. 11

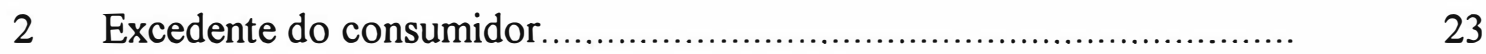

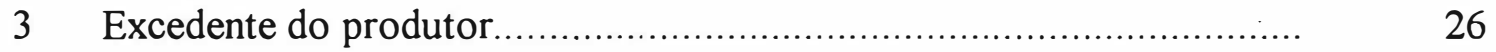

$4 \quad$ Equilíbrio no mercado de pescado..................................... 28

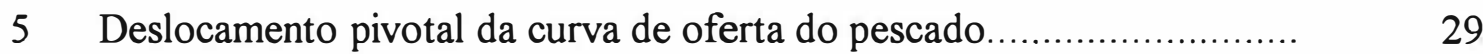

6 Deslocamento paralelo da curva de oferta do pescado....................... 29

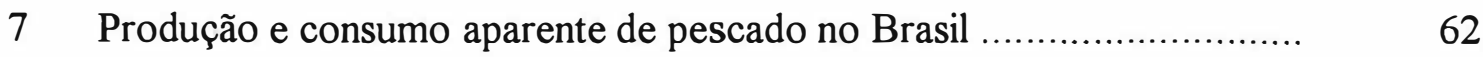

8 Exportação e importação de pescado no Brasil................................

9 Ganhos e perda do excedente econômico a partir do deslocamento da

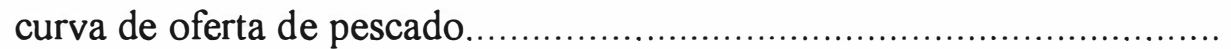




\section{LISTA DE TABELAS}

Página

1 Recursos setoriais captados, via incentivos fiscais, pelas respectivas áreas de aplicação, de 1967 a 1986, em mil reais de agosto de 1994

2 Produção, exportação, importação e consumo aparente do pescado no Brasil - 1960 a 1994

3 Participação da produção de pescado oriunda da pesca em água doce e marítima, no Brasil - 1960 a 1994.

4 Participação percentual das regiões na produção pesqueira do Brasil, 1972 a 1989

5 Preço por unidade da produção de pescado, por região, Brasil, 1980 a 1989 - em US\$/tonelada.

6 Recursos humanos envolvidos na aqüicultura, por região, 1995.

7 Número de aqüicultores e produção da aqüicultura para consumo, por região, 1995 
8 Dados usados para estimar equações de oferta e demanda de pescado no Brasil, 1960 a 1994.

9 Beneficio Social Total (BST) e Custo Social Total (CST) do programa de incentivos fiscais à pesca, 1967 a 1986

10 Número de estabelecimentos e valor da produção do grupo de indústrias que produzem alimentos, do subgrupo de prepara o pescado e fabrica conservas do pescado no Brasil, em 1970, 1975, 1980 e 1985

11 Número de estabelecimentos industriais de preparação e fabricação de pescado, por Estado, e participação relativa - 1993 e 1995.

12 Taxa média de crescimento do Valor da Produção Pesqueira (VPP), Brasil, 1960 a 1994.

13 Valor da Produção Pesqueira (VPP), Brasil - 1960 a 1994.

14 Número de pessoas ocupadas na produção pesqueira no Brasil, por setor de atividade, e participação percentual sobre o total de pessoas ocupadas no País (em 1960, 1970, 1980 e 1991).

15 Taxa média de crescimento do número de pescadores ocupados na agropecuária, produção extrativa vegetal e animal, e do número de pessoas ocupadas na indústria do pescado, 1960 a 1991 


\title{
ATIVIDADE PESQUEIRA NO BRASIL: POLÍTICA E EVOLUÇÃo
}

\author{
Autora: PATRÍZIA RAGGI ABDALLAH \\ Orientador: CARLOS JOSÉ CAETANO BACHA
}

\section{RESUMO}

Este estudo tem como objetivo analisar a evolução da atividade pesqueira no Brasil nas últimas quatro décadas e avaliar os impactos das políticas pesqueiras federais sobre essa atividade.

Para tanto, é feita uma análise das políticas federais voltadas para a atividade pesqueira no Brasil, demonstrando que essas políticas atuaram em dois sentidos: estabelecer regulamentações à atividade pesqueira (criando órgãos para coordenar a atividade pesqueira e estabelecendo medidas de ordenamento pesqueiro) e conceder incentivos à produção do pescado nacional.

Constatou-se que a política de regulamentação da atividade pesqueira no Brasil preocupou-se, durante muito tempo, com a criação de órgãos para regulamentar a extração do pescado (destacando a criação da Superintendência para o Desenvolvimento da Pesca, SUDEPE, a partir da década de 60, quando a atividade pesqueira tomou maior impulso), mas pouco se preocupou em diagnosticar e ampliar o estoque de pescado nacional, fato que somente se manifestou em período mais recente, a partir de 1989, com a criação do Instituto Brasileiro do Meio Ambiente e dos Recursos Naturais Renováveis (IBAMA). Do lado das regulamentações voltadas para o ordenamento pesqueiro, essas começaram a fazer parte ativamente da política pesqueira nacional a partir da década de 70, porém, tomaram maior dimensão a partir da segunda metade dos anos 80, num contexto de conservação dos recursos naturais renováveis.

A política que concedeu incentivos fiscais à produção pesqueira iniciou-se em 1967 com a promulgação do Decreto-lei $n^{0} 221$. Verificou-se que os incentivos fiscais concedidos a empreendimentos pesqueiros, de 1967 a 1986, contribuíram 
significativamente para ampliar a produção nacional de pescado e o parque industrial processador desse produto. Nos primeiros anos dessa política, mais de $50 \%$ dos recursos obtidos com essa política foram aplicados na indústria pesqueira, não havendo investimentos na área de pesquisa e levantamento de dados. Tal fato contribuiu para o aparecimento de sobreexploração de algumas espécies de recursos pesqueiros marítimos.

Para avaliar o Programa de Incentivos Fiscais à Pesca, estima-se um modelo tradicional de beneficio-custo baseado nos conceitos de excedente econômico. Constata-se que os beneficios sociais foram superiores aos custos sociais incorridos no programa em questão. Para cada $\mathrm{R} \$ 1,00$ de incentivo fiscal concedido, gerou-se beneficio social de $\mathrm{R} \$ 1,05$ a $\mathrm{R} \$ 2,06$ para os produtores e consumidores.

Finalmente, são avaliados os impactos econômicos e sociais do Programa de Incentivos Fiscais à Pesca sobre o segmento industrial do Sistema Agroindustrial do Pescado, sobre o valor da produção e na geração de emprego.

A análise mostra que, durante o período de vigência da política de incentivos, houve expressivo crescimento do número de estabelecimentos industriais processadores do pescado, do valor da produção pesqueira e do número de empregos criados na atividade de captura e de processamento do pescado (apesar desse volume de emprego ser pouco significativo em relação ao gerado em outros setores da economia). Não obstante, após o período de incentivos, a taxa de crescimento dessas variáveis declinou.

A queda do valor da produção e no ritmo de geração de empregos na atividade pesqueira e na atividade industrial a ela vinculada, no período pós incentivos fiscais à pesca, deveu-se à sobrepesca de algumas espécies de pescado. Essa, por sua vez, foi viabilizada pela política pesqueira federal, que esteve, durante muito tempo, preocupada com a captura, processamento e comercialização do pescado, pouco se preocupando com a questão dos estoques de pescado.

O trabalho se encerra com algumas propostas de correção da política pesqueira federal visando sanar o problema da sobrepesca, destacando-se: o aumento de investimentos em pesquisa e capital humano e a maior interrelação entre as políticas de 
regulamentação do uso dos recursos naturais renováveis, de forma a desenvolver conjuntamente atividades que envolvem esses tipos de recursos. 


\title{
FISHERY IN BRAZIL: ITS POLITICIES AND EVOLUTION
}

\author{
Author: PATRÍZIA RAGGI ABDALLAH \\ Adviser: CARLOS JOSÉ CAETANO BACHA
}

\section{SUMMARY}

The objectives of this study were to analyse the evolution of fishery in Brazil in the last four decades as well as to evaluate the impact of federal policies on the sector.

In order to achieve those objectives, an analysis of Brazilian federal policies for fishery was carried out, showing that they acted in two directions: in the regulation of fishery (by creating institutions in order to coordinate the fishery activity and by setting measures for fish arrangement) and in the creation of incentives to national fish production.

The results showed that Brazilian regulation policies for fishery were, for a long time, oriented towards the creation of regulatory institutions for fish catching, specially the creation of SUDEPE (Superitendence for Fishing Development) in the sixties, when fish activity was growing at high rates. Regulation policies, by then, were oriented towards increasing knowledge of neither the sector nor the stock size of national fish; only recently, as of 1989 , they became part of adopted policies for the sector with the creation of the Brazilian Environment and Renewable Natural Resources Institute (IBAMA). Regulations on fish arrangement became an active part of national fish policies only in the seventies, receiving more emphasis, however, in the late eighties, within the context of conservation of renewable natural resources.

The policy that conceived fiscal incentives to fish production began in 1967 with Government Decree number 221. It was verified that those incentives, from 1967 to 1986, significantly contributed to increase national production and industrialization of fish. In the first years of the period this policy was adopted, more than $50 \%$ of the financial resources went to the fish industry and away from investment in 
research and database generation. This fact contributed to the increase of overfishing of some species from the sea.

In order to evaluate the fish fiscal incentive program, a traditional cost/benefit model was estimated based on the concept of consumer surplus. The results showed that social benefits of the program were higher than social costs. For each $\mathrm{R} \$$ 1.00 of conceived fiscal incentive a social benefit of $R \$ 1.05$ to $R \$ 2.06$ was generated for consumers and producers.

Finally, the economic and social impacts of the Fishing Fiscal Incentive Program on the fishing indurtry, value of production and on employment generation, were evaluated.

The analysis showed that during the period the incentive program prevailed, there was a substantial increase of the number of fish industrial processing units, the value of fish production and of the number of jobs created in the fish catching and processing sectors (although the latter has been below other sectors of the economy). In the post-incentive period, however, the growth rates of these variables declined.

The reduction in production value and rate of job creation were due to overfishing of some fish species. This, in turn, was greatly facilitated by federal fishing policies which were, during long time, oriented towards fish catching, processing and marketing and away from controlling fish stock.

The study ends with some policy proposals for reorientation of federal fish policies in order to solve the overfishing problem. 


\section{INTRODUÇÃo}

\subsection{Apresentação}

O presente estudo analisa a evolução da atividade pesqueira no Brasil nas últimas quatro décadas e avalia os impactos das políticas pesqueiras federais sobre essa atividade.

Define-se como atividade pesqueira as ações que envolvem a captura e venda do peixe. Essa atividade faz parte do Sistema Agroindustrial do Pescado, que abrange as atividades de pesca (ou atividade pesqueira), as atividades fornecedoras de insumos à pesca (embarcações e redes, principalmente) e as atividades de industrialização e comercialização do pescado já processado. Por sua vez, entende-se por políticas pesqueiras aquelas cujo intuito é regulamentar e/ou promover a atividade pesqueira.

O pescado representa uma boa fonte alternativa de proteína para a alimentação humana. Segundo Paez (1991), o consumo de peixe proporciona vantagens para a saúde humana, porque este alimento contém baixo teor de gordura, contém o ácido ômega 3 (redutor de colesterol) e alta concentração de vitamina B.

Essas vantagens têm incentivado o consumo da carne de pescado em detrimento da carne vermelha, mudando o hábito alimentar do consumidor, principalmente nos países desenvolvidos. Segundo Wellmann (1990), nos Estados Unidos, a participação dos gastos com pescado no orçamento familiar aumentou em $130 \%$ desde 1967, enquanto as despesas com carne bovina decresceram $24 \%$ e as despesas com aves elevaram-se em 40\%. Short (1987) cita que o Departamento de Agricultura dos Estados Unidos (USDA) estima um crescimento do consumo médio per capita do pescado na 
ordem de $44 \%$ até o ano 2000 , enquanto que para a carne bovina, suína e de aves as estimativas situam-se, respectivamente, em torno de $30 \%, 12 \%$ e $7 \%$.

A atividade pesqueira ocorre em águas marítimas, estuarinas (junção de água doce com água salgada) e em água doce. A exploração dos recursos pesqueiros ocorre através da pesca extrativa (que extrai o pescado como um recurso natural renovável) e também através da pesca não extrativa (que tem o pescado como um produto cultivado, caso da aqüicultura).

Torna-se importante destacar as características básicas do recurso pesqueiro, não só como recurso natural renovável, como também sendo um recurso natural de propriedade comum e de acesso livre (exceto o cultivado em tanques). Essa característica do recurso pesqueiro ser um "bem público", de propriedade comum e de livre acesso, pode implicar o aparecimento da sobrepesca, propiciando a exaustão do mesmo.

A produção brasileira de pescado, segundo dados do Anuário Estatístico do Brasil, passou de 281,5 mil toneladas em 1960 para 971,5 mil toneladas em 1985. Contudo, desde 1986 essa produção vem caindo, tendo sido produzido 798,6 mil toneladas de pescado em 1989, atingindo 697,6 mil toneladas em 1994. Esta queda na produção nos últimos anos deve-se à redução na produção do pescado de origem marítima. Conforme Paez (1993) e Giulietti \& Assumpção (1995), a redução na produção pesqueira marítima, por sua vez, se deve à sobrepesca de algumas espécies, à predação dos recursos naturais e à conseqüente diminuição dos estoques.

Considerando o período de 1961 a 1994, tem-se que a participação média da produção de origem marítima na produção total do pescado no Brasil é de $78 \%$ ao ano, enquanto a participação média da produção pesqueira de origem de água doce representa apenas $22 \%$ ao ano.

A proporção elevada da pesca marítima no total produzido de pescado está relacionada à extensão do litoral brasileiro e, principalmente, à forma como se desenvolveu a pesca no país, começando sua exploração comercial pela pesca marítima (Diegues, 1995). De outro lado, a potencialidade produtiva dos recursos pesqueiros nas 
águas interiores brasileiras é pouco conhecida. Na bacia amazônica, por exemplo, das mais de duas mil espécies já identificadas, apenas 20 espécies de peixes são exploradas comercialmente (Neiva, 1990).

Além de, em média, $78 \%$ da produção pesqueira nacional ser oriunda de águas marítimas, observa-se que a produção brasileira de pescado origina-se, principalmente, da pesca extrativa, sendo pequena a participação da pesca não extrativa na composição dessa produção (Giulietti \& Assumpção, 1995).

A natureza da propriedade comum e de livre acesso do recurso pesqueiro propicia o aparecimento da sobrepesca, o que exige, portanto, a intervenção do Estado regulamentando a pesca de forma a evitar a superexploração.

O Brasil tem elaborado políticas de regulamentação da pesca. Essas políticas foram concebidas dentro de uma orientação de políticas macroeconômicas que se pautaram pela criação de órgãos regulamentadores de atividades de extração de recursos naturais renováveis e de concessão de incentivos fiscais ao desenvolvimento regional ou setorial.

Como exemplo dessas políticas, criou-se o Instituto Brasileiro de Desenvolvimento Florestal (IBDF) para regulamentar as atividades referentes à Floresta $\mathrm{e}$ Fauna Silvestre e, no caso da pesca, a Superintendência para o Desenvolvimento da Pesca (SUDEPE), uma autarquia vinculada ao Ministério da Agricultura, hoje já extinta. Atualmente, o Instituto Brasileiro do Meio Ambiente e dos Recursos Naturais Renováveis (IBAMA), órgão do Ministério do Meio Ambiente, dos Recursos Hídricos e da Amazônia Legal, possui, entre outros, o papel de desempenhar as atribuições da extinta SUDEPE. Como estímulo à atividade pesqueira foi criado e implementado, de 1967 a 1989, o Programa de Incentivos Fiscais à Pesca através do qual foram concedidos incentivos fiscais para dinamizar a captura e o processamento do pescado. 


\subsection{Revisão de literatura}

No Brasil, existem poucos estudos econômicos sobre as atividades que compõem o Sistema Agroindustrial do Pescado. Além disso, a maioria desses estudos trata de aspectos pontuais, muitas vezes analisados sob a ótica regional. Esses trabalhos se detêm em estudar aspectos relacionados à demanda, ao abastecimento, à comercialização, às variações de preços nos mercados, ao cálculo do custo de produção, entre outros temas econômicos específicos relacionados à pesca. Assim, estudando e estimando curvas de demanda de pescado para o Estado de São Paulo, tem-se os trabalhos de Morimoto (1975) e Cruz (1974); também pode-se citar os trabalhos de Carvalho \& Giulietti (1978b) e Moraes (1968) que analisam o consumo de pescado. O abastecimento de pescado à população urbana de baixa renda foi avaliado por Carvalho \& Giulietti (1978a) e Gallo (1976). Aspectos referentes à comercialização de pescado foram abordados por autores como Ferreira (1979), Carvalho (1980), Carvalho \& Giulietti (1978b). Quanto a trabalhos relacionados a estudos de mercado e variações de preços de pescado, podem ser citados: Azevedo et al. (1985), Ferreira (1980), Okawa (1985), Carvalho \& Arruda (1980). Calculando o custo de produção de pescado tem-se o trabalho de Chabalin (1996).

Torna-se interessante ressaltar, neste contexto, coeficientes de elasticidadepreço da demanda por pescado estimados por alguns autores acima citados, a fim de compará-los com o coeficiente a ser estimado neste estudo.

Morimoto (1975), ao analisar a estrutura de demanda doméstica de quatro espécies de pescado fresco no mercado da Grande São Paulo (sardinha, camarão, pescada e corvina), encontrou valores elevados para as elasticidades-preço da demanda dessas espécies. No caso da sardinha (que é uma espécie muito importante em termos de volume comercializado), a elasticidade-preço da demanda encontrada pelo autor, utilizando dados mensais de 1968 a 1973, foi de -1,36. Okawa (1985), ao realizar uma análise harmônica das variações dos preços e das quantidades de sardinha fresca no mercado atacadista de São Paulo, estudando as variações cíclicas dessas variáveis a partir de uma 
série temporal de dois anos, obteve elasticidade-preço da demanda de sardinha a curto prazo (com base no ciclo estacional) da ordem de $-1,82$, e a curtíssimo prazo (com base no ciclo lunar) da ordem de $-2,12$. Observa-se que essas elasticidades indicam demanda elástica, contrastando com a elasticidade-preço da demanda de sardinha da ordem de -0,519, obtida por Carvalho (1980).

A utilização de modelos bioeconômicos no gerenciamento da exploração sustentável de recursos pesqueiros no Brasil é recente e se restringe aos textos de Paez (1991, 1993).

São, também, escassos os estudos sobre a evolução da atividade pesqueira do País. Encontram-se alguns poucos textos como BRASIL (1988), um diagnóstico preparado pela Superintendência para o Desenvolvimento da Pesca (SUDEPE), analisando o setor pesqueiro no Estado de São Paulo; o trabalho de Giulietti \& Assumpção (1995), traçando um perfil da indústria pesqueira no Brasil; e, o estudo de Neiva (1990), apresentando subsídios para uma política pesqueira nacional.

Observa-se, da sintética exposição da literatura acima mencionada, que os estudos sobre economia da pesca no País não analisaram a política macroeconômica de regulamentação da atividade pesqueira e as políticas de incentivos a essa atividade.

De outro lado, a literatura internacional fornece um número bem maior de estudos sobre a economia pesqueira e, no que se refere aos temas citados no parágrafo anterior, pode-se citar trabalhos como: Anderson (1994), Arnarson (1993), Clark (1989), Campbell (1984), Hannesson (1994), Pearse (1981), Randall (1987), estudando a regulamentação econômica da pesca; e trabalhos como os de Anderson (1977), Gordon (1954), Randall (1987), Paez (1981) e Troadec (1983), focalizando temas mais abrangentes sobre a economia pesqueira, como os aspectos relacionados à política econômica para a atividade pesqueira e a teoria econômica adequada a entender a exploração de um recurso de propriedade comum como o pescado. 


\subsection{Objetivos}

A revisão bibliográfica feita no item anterior demonstra a necessidade de estudos mais abrangentes sobre a evolução da atividade pesqueira no Brasil, bem como pesquisas sobre a avaliação econômica dos impactos de políticas federais sobre essa atividade.

Assim sendo, o objetivo geral do presente estudo é analisar a evolução da atividade pesqueira no Brasil nas últimas quatro décadas e avaliar os impactos das políticas pesqueiras federais sobre essa atividade.

Os objetivos específicos são:

a) analisar as políticas públicas federais de incentivo à atividade pesqueira a partir da década de 60 , discutindo-as dentro do contexto nacional e internacional em que foram elaboradas;

b) estudar a evolução da atividade pesqueira do Brasil, analisando a sua distribuição geográfica e o valor da produção; e,

c) avaliar o programa de incentivos fiscais à pesca através de uma análise beneficio-custo.

A presente pesquisa se justifica na medida em que são necessárias mais informações e conhecimento sobre a atividade pesqueira nacional, com o propósito de melhorar as políticas elaboradas para essa atividade, ou eventualmente contribuir para a definição de novas políticas.

\subsection{Hipótese}

A hipótese central deste trabalho é que a política pesqueira esteve preocupada com a captura, processamento e comercialização do pescado, pouco atentando à questão do estoque de pescado. A orientação do Governo Federal era a de criar órgãos regulamentadores da atividade de extração de peixes e fornecer incentivos fiscais ao desenvolvimento da captura, processamento e comercialização do pescado. Nesta orientação, a política pesqueira esteve coerente com outras políticas 
macroeconômicas desenvolvimentistas e intervencionistas criadas para desenvolver outras atividades (inclusive as baseadas na exploração de recursos naturais).

\subsection{Organização do trabalho}

Além desta introdução, esta pesquisa consta de mais 4 capitulos. O capitulo 2 apresenta o referencial teórico e metodológico. O capítulo 3 aborda a evolução da atividade pesqueira no Brasil e da política federal a ela relacionada. No capitulo 4 é feita uma análise beneficio-custo dos programas federais de incentivo à pesca. No capitulo 5 faz-se uma análise dos impactos do programa de incentivo fiscal à pesca sobre o segmento industrial do Sistema Agroindustrial do Pescado no Brasil, sobre o valor da produção pesqueira, e analisa a geração de empregos na atividade pesqueira. Com as informações dos capitulos anteriores, no capítulo 6 são elaboradas as conclusões da tese e algumas sugestões que podem ser incluídas em uma nova proposta de política pesqueira nacional. 


\section{REFERENCIAL TEÓRICO E METODOLÓGICO}

Neste capítulo, é apresentado o referencial teórico que aborda o pescado como um recurso natural renovável, de propriedade comum e de livre acesso. No item 2.1 são apresentadas as teorias concernentes à exploração racional do recurso pesqueiro (numa abordagem de bioeconomia dos recursos pesqueiros), os modelos de exploração ótima do recurso (máximo rendimento econômico e máximo rendimento biológico) e os modelos de intervenção do Estado (com teorias voltadas para a regulamentação econômica da pesca). No item 2.2 são apresentados os aspectos relacionados com o desenvolvimento de modelos de análise benefício-custo e o modelo específico adotado na presente tese.

\subsection{O pescado como recurso natural renovável, de propriedade comum e de livre} acesso.

McKelvey (1989) define recursos pesqueiros como recursos biológicos que, por sua natureza, são renováveis, mas podem ser também exauriveis. Essa característica de ser renovável implica dizer que as populações desse recurso mantêm rendimentos que são sustentáveis na natureza. Com a interação das condições biológicas, ambientais e intensidade de pesca impostas pelo homem, tem-se a magnitude dos estoques existentes. Os dois primeiros fatores (características biológicas da espécie e condições ambientais) são muito dificeis de serem controlados ou alterados pelo homem quando comparados ao que se pode obter em relação ao terceiro fator (a intensidade de pesca ). Este último é resultante dos beneficios econômico e social que o homem obtém (ou espera obter) da exploração dos recursos naturais. 
O equilíbrio dinâmico do estoque de pescado é mantido uma vez que as perdas, causadas pela mortalidade natural, são contrabalançadas pelos ganhos ocasionados pela reprodução e pelo crescimento natural. Entretanto, quando há pesca imposta pelo homem, dependendo de sua intensidade, pode ocorrer desequilíbrio na sustentabilidade do recurso, podendo torná-lo exaurível.

Além de ser recurso natural renovável, os recursos pesqueiros originários da natureza são caracterizados como bem público, não exclusível, ou seja, são recursos de propriedade comum e de livre acesso. Randall (1987) aponta a não exclusividade como um fator de ineficiência do mercado na valoração de um recurso natural (como o peixe) e ressalta que a grande mobilidade dos peixes torna impossível definir, e fazer valer (enforcement), direitos de propriedade exclusivos sobre os peixes (indivíduos) em particular, ou cardumes de peixes, ou mesmo confiná-los em áreas delimitadas do oceano.

A implicação econômica do livre acesso (não exclusividade) a um recurso natural (por exemplo, um estoque de pescado) é que o recurso não é avaliado por um preço, ao contrário do produto - o peixe, por exemplo - que tem um preço. Não sendo necessário pagar pelo recurso, as pessoas entrarão na pescaria e os lucros obtidos nessa atividade serão investidos em equipamentos de pesca, enquanto esses lucros forem superiores aos auferidos em aplicações alternativas. Entretanto, quando, posteriormente, a produtividade cair devido à sobrepesca, os bens de capital adquiridos deixarão de ter mercado, enquanto os custos operacionais por unidade de pescado produzida tornar-seão cada vez maiores.

Uma vez que está sendo considerado um recurso natural renovável e exaurível, há necessidade de se controlar a pesca realizada pelo ser humano, que desequilibra o estoque desse recurso. Esse controle se materializa através de regulamentações da atividade pesqueira. No entanto, o fundamento que propicia estabelecer tais regulamentações (voltadas para a exploração racional dos recursos pesqueiros) requer a integração da análise biológica à análise econômica. Dessa forma, os modelos bioeconômicos mostram-se essenciais para a questão de regulamentação da pesca. 


\subsubsection{Abordagem bioeconômica dos recursos pesqueiros}

Como a intensidade da pesca é um fator importante para definir o estoque de pescado (podendo, inclusive, tornar questionável o caráter renovável deste recurso), surge como aspecto relevante o gerenciamento da exploração dos recursos pesqueiros para viabilizar a obtenção do melhor proveito possível dessa atividade sem, contudo, comprometer o estoque de peixes.

O estudo do crescimento e do comportamento dos estoques, sob o ponto de vista estritamente biológico, fundamenta-se na teoria da dinâmica da população. A partir dos anos 50, autores como Schaefer (1954), Beverton \& Holt (1957) e Pella \& Tomlinson (1969) desenvolveram modelos biológicos para explicar a dinâmica da população de um dado estoque de peixes e predizer o máximo nível de captura possível em bases sustentáveis. Esses modelos são importantes na medida que o gerenciamento da exploração de recursos pesqueiros requer a integração de análises biológicas à análise econômica.

Na definição de Bertolotti (1989), o termo bioeconômico envolve as interrelações entre os fatores econômicos, que afetam a atividade pesqueira, e os biológicos, que determinam a reprodução e provisão de peixes.

Ao longo dos anos, vários autores (Gordon, 1954; Randall, 1987; Clark, 1989; Hannesson, 1987 e McKelvey, 1989) têm estudado a melhor intensidade da atividade pesqueira sem comprometer o estoque de peixes, possibilitando a caracterização da função de produção pesqueira ou da função de rendimento sustentável.

Na versão de Bertolotti (1989), o modelo de Gordon (1954) é o ponto de partida para a análise teórica da economia da pesca. Definindo captura como a quantidade pescada do produto (no caso, o pescado) e esforço de pesca como a energia despendida para capturar o pescado (que pode ser medido de várias formas, como por exemplo: número de viagens dos barcos e número de lances de redes ao mar) e utilizando 
fundamentos da análise microeconômica convencional (teoria da produção e dos custos), Gordon (1954) chega a um modelo de produção pesqueira. Neste modelo, são definidos pontos de:

- máximo rendimento econômico ou o ótimo econômico, isto é, o ponto onde a receita marginal se iguala ao custo marginal em um nível de esforço de pesca reduzido representado pelo nível de esforço de pesca $\mathrm{E}_{1}$ na Figura 1;

- máximo rendimento sustentável ou o ótimo biológico, isto é, o ponto onde a receita marginal é zero em um nível de esforço de pesca máximo, dentro das condições de sustentabilidade do recurso - representado pelo nível de esforço de pesca $\mathrm{E}_{\mathrm{MAX}}$ na Figura 1;

- ponto de equilibrio bioeconômico, isto é, o ponto onde o valor total das capturas - a receita total - se iguala ao seu custo total, num nível de esforço de pesca acima do nível máximo sustentável - representado pelo nível de esforço de pesca $E_{3}$ na Figura 1.

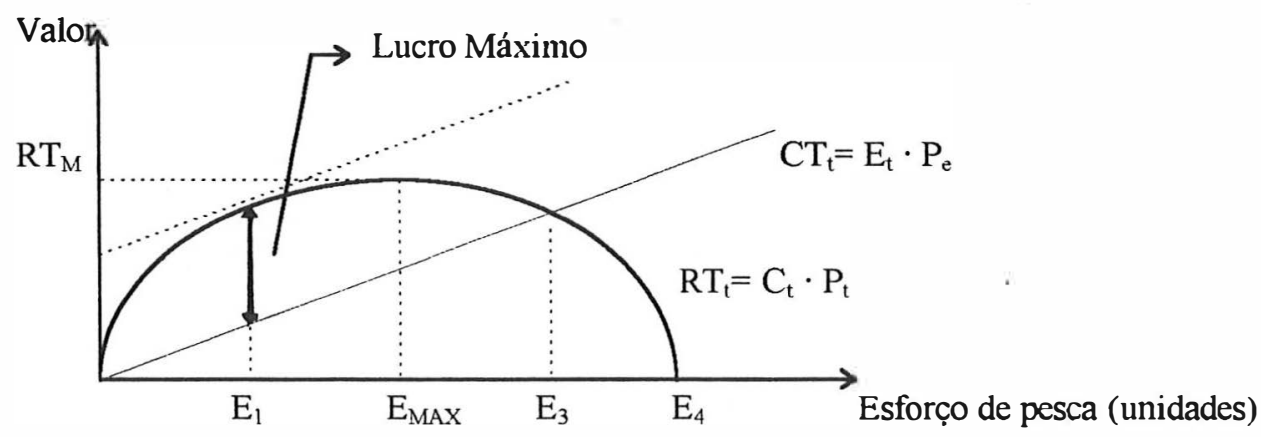

Figura 1 - Curvas de Receita Total $\left(\mathrm{RT}_{\mathrm{t}}\right)$ e Custo Total $\left(\mathrm{CT}_{\mathrm{t}}\right)$ a preços constantes. Nota: Receita Total no momento $t\left(R T_{t}\right)=$ Captura no momento $t\left(C_{t}\right)$. preço do pescado no momento $t\left(\mathrm{P}_{\mathrm{t}}=\right.$ constante); Custo Total no momento $t$ $\left(C T_{t}\right)=$ esforço de pesca no momento $t\left(E_{t}\right) \cdot$ custo do esforço de pesca $\left(P_{e}=\right.$ constante).

A principal predição do modelo de Gordon (1954) pode ser expressa da seguinte forma: em uma pescaria, não regulada e de livre acesso, o esforço de pesca se expandirá até um nível no qual a receita total se igualará ao custo total. Este nivel de esforço de pesca (nível $E_{3}$ na Figura 1) representa um equilibrio no qual as forças 
econômicas, que afetam os pescadores, e as forças biológicas, que afetam a produtividade do cardume, se encontram equilibradas (Bertolotti, 1989). Contudo, o esforço de pesca $\mathrm{E}_{3}$ ultrapassa o ponto de máximo rendimento econômico (que ocorre no esforço de pesca $E_{1}$ ) e o ponto de máximo rendimento sustentável (que ocorre no esforço de pesca $E_{M A X}$ ). Paez (1991, p.96) descreve de forma clara o comportamento da exploração racional dos recursos pesqueiros, demonstrados por modelos bioeconômicos. Segundo esta autora:

"Porque nenhum pescador detém direito exclusivo de propriedade e não pode evitar a exploração de um dado recurso por outrem, as embarcações encontram-se em competição para obter o maior volume possivel de captura em uma dada área de pesca. Em conseqüência, manifesta-se tendência de sobrepesca, desde que inexiste incentivo de manter o esforço de captura próximo do máximo rendimento físico sustentável. Rompe-se, assim, o equilibrio biológico entre a taxa de exploração e a taxa de renovação, que garante a perpetuação dos estoques. Adicionalmente, com a ausência de direitos de propriedade e com o acesso livre, o nível do esforço de pesca tenderá a ultrapassar também aquele limite de máximo rendimento econômico, em que a receita marginal iguala ao custo marginal. Excedentes unidades de esforço de pesca são utilizadas e, neste caso, a renda econômica (atribuida a um recurso de propriedade privada, como a renda da terra) é dissipada entre os barcos da frota que, em conjunto, participam da exploração comercial de um dado estoque. Enquanto houver possibilidade de auferir lucro, pescadores estarão motivados a intensificar esforço de pesca e/ou entrar em atividade. Nestas condições, o equilíbrio estável na exploração pesqueira é atingido quando a receita total se igualar ao custo total. Isto redunda em externalidade tecnológica. É extemalidade porque cada barco não exerce controle sobre sua produtividade. É tecnológica porque a produtividade de cada barco é afetada pela captura total, que tende a decrescer com o aumento indiscriminado do esforço de pesca".

Scott (1955) aborda, sob o enfoque estritamente econômico, que os programas destinados à administração racional dos recursos pesqueiros devem realocar os fatores de produção de forma que maximizem o valor líquido da produção pesqueira. Essa realocação dos fatores de produção seria obtida através da redução induzida do esforço de pesca. A redução do esforço de pesca deslocaria a atividade pesqueira do ponto de equilibrio bioeconômico (ponto onde a receita total é igual ao custo total representado pelo nível de esforço de pesca $E_{3}$ na Figura 1) para o ponto de ótimo 
econômico (ponto de lucro máximo, onde a receita marginal é igual ao custo marginal representado pelo nível de esforço de pesca $\mathrm{E}_{1}$ na Figura 1).

De acordo com Paez (1993), a maioria dos programas de administração dos recursos pesqueiros tem sido orientada para controlar a habilidade da frota pesqueira em realizar o esforço de pesca. Essa orientação advém da necessidade de preservar os recursos pesqueiros de uma potencial exaustão. O controle da habilidade da frota pesqueira propicia um correto volume de captura, sob o enfoque de sustentabilidade biológica do estoque (ou seja, pelo menos que atinja no máximo o nível de esforço de pesca $E_{\text {MAX }}$, representado na Figura 1).

Os estudos sobre exploração dos recursos pesqueiros provocaram comentários e críticas de, entre outros, Seijo et al. (1996) e Bertolotti (1989).

Os modelos bioeconômicos são construídos para realizar predições. De acordo com Bertolotti (1989) estas predições servem para guiar a ação humana e por em prova a eficácia de um plano de manejo.

Para Seijo et al. (1996), os modelos bioeconômicos e as simulações são muito úteis, mesmo quando as predições não são exatas devido a simplificações ou falta de dados. Esses modelos, mesmo não solucionando problemas da exploração de recursos pesqueiros são, ao menos, capazes de identificar problemas e demonstrar a direção e a magnitude dos resultados de uma determinada política.

Segundo Bertolotti (1989), na situação atual dos países da América Latina, parece adequada a utilização dos modelos estáticos e determinísticos (como o modelo de Gordon, 1954) para uma análise inicial de cada pescaria. Entretanto, os requisitos de informações prévias às modelagens são os limitantes mais importantes. É necessário contar com boas e confiáveis fontes estatísticas que forneçam dados de captura, desembarques, esforço efetivo de pesca, idades, crescimento, tamanho, mortalidade, coeficiente de captura, abundância do recurso, custo do esforço, custos dos desembarques etc.

Ainda segundo Bertolotti (1989), os modelos bioeconômicos referem-se a partes ou aspectos do mundo natural, econômico e social. Esses modelos não consideram 
o sistema econômico no qual estão inseridos (em especial o sistema econômico pesqueiro) e, portanto, a estrutura do mesmo. Segundo Bertolotti (1989, p. 16):

"Ao transformar as curvas de rendimento resultantes dos modelos de produção e dos modelos analíticos em seus equivalentes econômicos (modelos bioeconômicos) aparecem outros problemas relacionados com os pressupostos da Teoria Geral da Produção e com a análise parcial do sistema econômico analisado.

A análise do sistema econômico pesqueiro em particular, sua estrutura e seu comportamento, podem ser incorporadas como variáveis exógenas a serem analisadas simultaneamente com as modelações parciais realizadas.

O avanço do desenvolvimento específico dos modelos para os casos particulares pode melhorar substancialmente, com estudos estruturais que explicam o comportamento da atividade pesqueira.

Classificações de frotas (padronização), análises de concentração e integração produtiva (captura, processamento, mercados), estudos sobre a formação de preços, distribuição de renda entre os participantes do processo produtivo, entre outros, contribuem para o conhecimento global do setor pesqueiro e podem justificar ou não as políticas de manejo dos recursos que se desprendem dos modelos utilizados".

No Brasil, o desenvolvimento dos instrumentos de análises bioeconômicas mostrou-se necessário principalmente a partir da década de 30. Antes de 1930, o volume capturado de pescado era pequeno e era inexpressiva a preocupação em definir e implementar políticas públicas voltadas para a exploração sustentável do recurso pesqueiro. A partir de 1930, maiores atenções se voltam no sentido de estabelecer políticas para regulamentar a atividade pesqueira no País. No entanto, em períodos mais recentes, surge a necessidade de se atuar com políticas específicas para explorar de forma sustentável o recurso pesqueiro, dada a tendência de esgotamento de muitas espécies e até mesmo a exaustão de certas espécies (Paez, 1993). É nesse contexto que se destaca a importância do uso de análises bioeconômicas para melhor definir políticas que conduzam à exploração racional do recurso pesqueiro.

São apresentadas, a seguir, algumas regras de acesso aos recursos pesqueiros que, se implementadas num sistema sustentado por análises bioeconômicas 
bem elaboradas, resultariam em explorações de forma racional do recurso, dando ênfase ao aspecto da sua sustentabilidade ${ }^{1}$.

\subsubsection{Modelos de Intervenção do Estado: teorias voltadas para a regulamentação econômica da pesca}

Há um consenso entre os autores que estudam a exploração dos recursos pesqueiros de que a principal causa do superdimensionamento do esforço de pesca é a falta de definição dos direitos de propriedade.

Para Randall (1987), entretanto, não é possível atribuir direitos de propriedade exclusivos aos recursos pesqueiros situados no mar. Essa impossibilidade em definir direito de propriedade é devida aos recursos pesqueiros serem considerados bens públicos e de propriedade comum.

Por essa razão, a administração da atividade pesqueira pode ser feita com base num sistema de direitos praticáveis. São estabelecidas regras de acesso aos recursos pesqueiros. Como exemplo, essas regras referem-se a: imposição de taxas, concessão de licenças de pesca, estabelecimento de cotas de captura, suspensão da pesca em determinadas áreas ou durante certas estações do ano, limitação do tamanho mínimo do peixe capturado, seletividade imposta ao uso dos implementos de pesca e limitação do número de barcos.

Segundo Randall (1987), estabelecer regras de acesso ao recurso pesqueiro é uma forma de regulamentar a atividade. Entretanto, para implantar tais regras, o Governo necessita estabelecer uma agência que tenha autoridade de fato e de direito $^{2}$.

\footnotetext{
${ }^{1}$ O Brasil não tem experiência em modelagens bioeconômicas como instrumental prévio às formulações de regulamentações para explorar a pesca de forma sustentável. A justificativa para essa realidade passa pela falta de investimentos em pesquisa, estudos especificos de custos e existência de banco de dados que permitam tal análise.

${ }^{2}$ Como forma de discutir melhor a administração das atividades da pesca, a literatura intemacional apresenta uma série de estudos referentes à regulamentação pesqueira. Alguns trabalhos podem ser citados, como: Randall (1987), Anderson (1994), Arnarson (1993), Clark \& Major (1988), Campbell (1984), Hannesson (1994) e Pearse (1981).
} 
Segundo Troadec (1983), a razão fundamental para a regulamentação pesqueira e, em especial, a regulamentação econômica, é a natureza da propriedade comum dos recursos.

A seguir, analisam-se as seguintes formas de regulamentação da pesca: delimitação das estações do ano em que se permite a pesca, licenças de pesca, restrições aos equipamentos e insumos autorizados na pescaria, cotas individuais de pesca e tributação, bem como a combinação de algumas dessas formas de regulamentação.

\section{- Limitar a pesca por "tempo"}

Esta regulamentação estabelece estações do ano em que se permite a pesca. A idéia é limitar os dias liberados para pescar e, assim, manter o estoque reprodutivo de peixes.

Conforme Randall (1987), esta regra não garante, por si só, que haverá exploração racional dos recursos pesqueiros. Com uma estação de pesca restrita (poucos dias permitidos para pescar), um pescador compete com outro para comprar e usar o maior e mais rápido barco de pesca e a mais efetiva tecnologia para capturar o pescado. Essa competição entre pescadores (por uma produtividade maior na pescaria: "quem captura mais num limitado tempo de pesca") induz a elevados investimentos em equipamentos e técnicas de captura (barcos, redes, tecnologias apropriadas para localizar cardumes, etc). Dessa forma, mesmo com poucos dias permitidos para a pescaria, a tendência é um grande volume de pescado capturado (devido aos investimentos tecnológicos na atividade pesqueira). Assim sendo, limitar a pesca apenas por "tempo", segundo esse autor, é ineficaz.

\section{- Licenças de pesca}

Este instrumento implica emitir licenças de pesca em número limitado. Dessa forma, restringe-se o número de barcos autorizados a pescar. O propósito dessa regulamentação é controlar o esforço de pesca. 
Segundo Clark (1989), essa regulamentação induz os proprietários de barcos licenciados a investirem mais em equipamentos de captura, aumentando o poder de pesca efetivo de seus barcos. Com uma infra-estrutura melhor na captura do pescado, essa forma de regular a pesca torna-se ineficaz em reduzir o esforço de pesca.

\section{- Restringir tipos de insumos utilizados na pesca}

O controle de insumos utilizados na atividade pesqueira pode ser feito limitando o tamanho do barco de pesca, limitando sua capacidade para estocar e refrigerar o pescado, restringindo ou proibindo o uso de aparelhos para localizar cardumes, entre outras formas.

Para Randall (1987), o controle de insumos utilizados na atividade pesqueira é ineficiente para conservar o recurso pesqueiro. Um pescador habilidoso, em pouco tempo, substituiria os insumos com restrição por outros insumos. Essa regulamentação resultaria em alocação ineficiente de recursos para regulamentar a pesca.

\section{- Cotas individuais transferiveis}

Nesta forma de regulamentar, estabelecem-se cotas individuais de captura de uma determinada espécie. Essas cotas são determinadas com base em estudos biológicos e considerando o estado de conservação em que se encontra o estoque de pescado.

Cada pescador, uma vez que sua cota fosse estabelecida (no caso, por uma agência do governo responsável por essa atribuição), estaria livre para determinar a melhor combinação de custo de insumos (capital, tecnologia, trabalho e tempo).

Portanto, cada barco, individualmente, teria sua cota de produção. Se o dono do barco decide não utilizá-la totalmente, pode vender parte da cota a outro pescador. Aqueles que decidirem expandir suas atividades poderão comprar as cotas de outros

Segundo Clark (1989), por serem cotas individuais transferiveis (podendo ser vendidas entre pescadores), o processo de ajustamento dinâmico na atividade 
pesqueira seria encorajado. Pescadores mais produtivos expandiriam suas operações e usariam tecnologias mais modernas para reduzir custos.

\section{- Taxas}

Conforme Randall (1987), se o problema é superexploração do recurso pesqueiro, a solução preferida deve ser a restrição da exploração do recurso através de taxações. Pode-se estabelecer, por exemplo, uma taxa por peixe capturado e comercializado, ao invés de restringir o uso de vários insumos no processo de exploração.

- Combinação de instrumentos de regulamentação

$\mathrm{O}$ estabelecimento de cotas individuais transferíveis juntamente com a imposição de taxas constituem os tipos de regulamentação mais discutidos na literatura em questão.

O Estado pode apropriar-se parcialmente da renda potencial do recurso pesqueiro em dois momentos distintos: antes da captura, através de um pagamento por parte do pescador pela obtenção da licença de pesca, ou após a captura, na forma de impostos, taxas etc.

Na versão de Clark (1985), cotas devem ser distribuídas e transferíveis.

Dessa forma, o intercâmbio gerará um mercado de cotas e o preço da cota resultante será equivalente a um imposto sobre a produção.

Segundo Bertolotti (1989), na economia da regulamentação pesqueira, o controle de preços (através de taxas, impostos etc.) e o controle de quantidades (através de cotas) têm efeitos equivalentes sobre a produção. A grande diferença é que no primeiro caso (controle de preços), parte da renda gerada pelo recurso é apropriada pelo Estado e no segundo caso (controle de quantidades), a renda gerada pelo recurso é apropriada pelos pescadores.

Paez (1993) sugere que, a partir das estimativas da função de rendimento sustentável, o critério a ser considerado na escolha do método de controle do esforço de 
pesca é o do custo de instituir e cumprir tal regulamentação ser inferior ou igual ao valor potencial de seus beneficios.

São várias as formas de regulamentação da pesca utilizadas no Brasil. No entanto, essas formas se concentram mais em limitar a pesca por tempo, em conceder licenças para pescar e em restringir os tipos de insumos utilizados na pesca. São poucas as regulamentações brasileiras que restringem a pesca através do estabelecimento de taxas (controlando o preço do pescado). Informações mais detalhadas dos tipos de intervenções adotadas no Brasil são apresentadas no Capitulo 3, sub-item 3.1.1.

\subsection{Aspectos teóricos referentes à análise benefício-custo e apresentação de um modelo de cálculo do Benefício Social dos Incentivos Fiscais à atividade da pesca no Brasil.}

A análise beneficio-custo social é um instrumental freqüentemente utilizado em análise econômica para questionar se a sociedade, como um todo, ficará em melhor situação empreendendo ou não um determinado projeto ou, então, empreendendo um dentre uma série de projetos alternativos. A mesma análise é também utilizada para avaliar, ex-post, os resultados obtidos com certo empreendimento e compará-los com os custos efetivos desse empreendimento.

Conforme Mishan (1976), na análise de beneficio-custo social considera-se a sociedade em seu conjunto (analisa-se o bem-estar de uma sociedade definida) e não apenas uma de suas partes. Nesses termos, a economia substitui o conceito de receita da empresa privada pelo conceito de beneficio social.

Existe um grande número de trabalhos que já fizeram uso da análise de benefício-custo social para avaliar empreendimentos (como o da inovação tecnológica) 
feitos para a agricultura. Muitos desses trabalhos utilizam os conceitos de excedente econômico do consumidor e excedente do produtor ${ }^{3}$.

Norton \& Davis (1981) discutem diversos modelos que calculam o beneficio social (resultante de investimentos em pesquisa na agricultura) com base nos conceitos de excedente do consumidor e de excedente do produtor. Dentre esses modelos, destacam-se os desenvolvidos por Schultz (1953), Griliches (1958), Peterson (1967), Akino \& Hayami (1975), Lindner \& Jarrett (1978) e por Rose (1980). Em essência, esses modelos calculam o aumento do excedente total quando a curva de oferta de um determinado produto se desloca para a direita (deslocamento esse devido à adoção de uma inovação tecnológica na agricultura) e comparam o aumento do excedente com os custos incorridos para gerar a inovação tecnológica.

No Brasil, foram feitos alguns trabalhos utilizando os modelos acima mencionados, dentre os quais pode-se citar os de Ayer \& Schuh (1974), Monteiro (1975), Fonseca (1976), Ferreira (1993), Silva \& Khan (1994), Santana \& Khan (1992) e Bacha (1995).

Ayer \& Schuh (1974) analisaram as taxas de retorno social da pesquisa com algodão no Estado de São Paulo, utilizando a metodologia que considera o deslocamento da curva de oferta em virtude da introdução da nova tecnologia. Para tanto, trabalharam com os conceitos econômicos de excedente do consumidor e excedente do produtor e encontraram taxa de retorno social variando entre $77 \%$ a $110 \%$ ao ano.

Monteiro (1975) fez uma avaliação econômica do programa de pesquisa e extensão agrícola à cultura do cacau no Brasil, para o período de 1923 a 1975. Ao

\footnotetext{
${ }^{3}$ Além desses, existem outros estudos econômicos que utilizam metodologias diversas de cálculo do benefĩcio-custo para avaliar desempenhos de políticas sobre o sistema econômico e/ou social. Como exemplo tem-se Motta (1987) que fèz uma avaliaçào social do Proálcool, utilizando a tradicional análise benefício-custo, estimando os custos de oportunidade dos recursos alocados nesse Programa; Tourinho et al. (1987) que utilizaram um modelo de programação linear para examinar deslocamentos espaciais e temporais das culturas provocados pelo Proálcool, calculando, para tal, o custo social do álcool; Montoya et al. (1998) que avaliaram os custos e benefĩcios intersetoriais na agroindústria, derivados da competitividade na produção de grãos entre Argentina e Brasil, usando o instrumental insumo-produto. Entretanto, de forma a atingir um dos objetivos proposto na presente tese, utilizou-se nesse estudo a análise benetício-custo social com base nos conceitos de excedente econômico para avaliar o programa de incentivos fiscais à pesca no Brasil.
} 
estimar o excedente econômico desse programa, o autor calculou somente o excedente do produtor. Esse procedimento se justifica na medida em que, sendo o cacau um produto essencialmente de exportação, o excedente do consumidor se refere ao excedente do consumidor externo. $\mathrm{O}$ autor utilizou diversas pressuposições ao estimar a taxa interna de retorno, sendo a menor taxa encontrada no estudo de $19 \%$ ao ano para a pesquisa em cacau na Bahia.

Fonseca (1976) tomou como base o programa de pesquisa cafeeira desenvolvido pelo Estado de São Paulo (do final da década de 30 ao início da década de 70), e estimou os retornos à sociedade advindos dos investimentos realizados nesta cultura. Seu estudo usa os conceitos econômicos de excedente do consumidor e excedente do produtor para realizar os cálculos e obteve a taxa de retorno social variando entre $23,2 \%$ e $26 \%$ ao ano para a pesquisa cafeeira (considerando o período de 1933 a 1975).

Ferreira (1993) utilizou o procedimento tradicional de cálculo dos excedentes econômicos com o objetivo de obter o retorno aos investimentos em pesquisa e assistência técnica na cultura do café, no Estado de Minas Gerais, nas décadas de setenta e oitenta. Obteve-se a taxa de retorno social de $82,06 \%$ ao ano em pesquisa e assistência técnica para o café (pressupondo que os beneficios iniciaram-se em 1975). Essa taxa de retorno aproxima-se das taxas encontradas por Ayer \& Schuh (1974) e se mostram aparentemente altas se comparadas às taxas obtidas pelo trabalho de Fonseca (1976).

Silva \& Khan (1994) calcularam os beneficios sociais da substituição de milho por raspa de mandioca no uso da ração suína, no Estado do Ceará. O modelo utilizado para calcular os beneficios sociais foi elaborado com base no conceito de excedente econômico do consumidor e de excedente do produtor. Esse modelo permitiu calcular os benefícios sociais oriundos diretamente da substituição do milho pela raspa de mandioca (ou seja, o acréscimo do excedente total quando do deslocamento da curva de oferta de carne suína devido à substituição do milho pela raspa de mandioca) e os beneficios sociais oriundos indiretamente da substituição do milho pela raspa de 
mandioca (ou seja, os beneficios sociais gerados pelo deslocamento da curva de demanda por mão-de-obra rural resultante de um acréscimo de mão-de-obra empregada no setor rural proveniente da maior procura por mandioca). As principais conclusões do trabalho indicam que quanto maior o grau de substituição do milho por raspa de mandioca, maiores serão os beneficios sociais. Essa substituição de alimentos conseguiu elevar o nível de emprego no setor rural. Os resultados revelaram beneficios para a sociedade cearense como um todo, sendo os produtores o segmento mais beneficiado.

Santana \& Khan (1992), analisando o fenômeno do desflorestamento na região produtora de castanha no Estado do Pará, utilizaram o conceito de excedente econômico marshalliano para medir os custos sociais desse desflorestamento. Constataram que os consumidores são os mais afetados pela destruição das castanheiras, afetando assim a sociedade como um todo. Mostraram também que, ao continuar a depredação, a extração desse recurso natural tendeu para a exaustão, sendo atribuído aos "direitos de propriedade" o fator limitante nessa atividade extrativa.

Baseado no modelo de Santana \& Khan (1992), Bacha (1995) desenvolveu um modelo de cálculo do beneficio social dos incentivos fiscais concedidos à atividade de reflorestamento no Brasil. Foi costatado que, no período de 1972 a 1990, o benefício social foi bem menor que o custo incorrido com tais incentivos (cerca de $0,16 \%$ e $0,25 \%$ do custo, considerando, respectivamente, um deslocamento pivotal e paralelo da curva de oferta).

Segundo Tweeten (1989), os conceitos de excedente do consumidor e excedente do produtor, divulgados por Marshall, são muito úteis para a análise de política econômica, não obstante, sofrerem críticas relevantes. A seguir, faz-se uma breve apresentação desses conceitos, ressaltando as críticas. 


\section{- Excedente do consumidor}

Na definição de Marshall (1982), excedente do consumidor é a diferença entre o que o consumidor estaria disposto a pagar por uma dada quantidade total de um bem e o que ele realmente paga.

Na Figura 2, se o preço de um bem $\mathbf{x}$ é $\mathrm{p}_{1}$ e o consumidor compra $\mathrm{q}_{1}$ unidades da mercadoria $\mathbf{x}$, seu dispêndio total com a mercadoria é $\mathrm{p}_{1} \mathrm{q}_{1}$ (representado pela área a). A área sob a curva de demanda (DD) de 0 até $q_{1}$ unidades da mercadoria $\mathbf{x}$ representa a soma de dinheiro que o consumidor estaria disposto a pagar por $\mathrm{q}_{1}$ unidades (correspondente à área $\mathbf{a}+\mathbf{b}$ ). A diferença entre o que ele estaria disposto a pagar (área a+b) e o que ele realmente paga (área a) é o excedente do consumidor, representado pela área triangular abaixo da curva de demanda (DD) e acima da linha de preço $\mathrm{p}_{1}$ (área b).

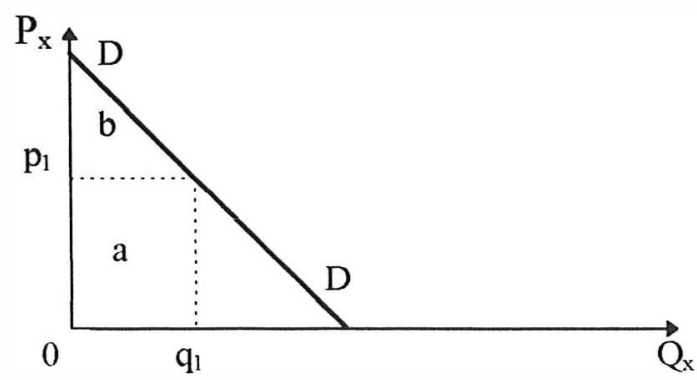

Figura 2 - Excedente do consumidor (área b).

Nota: $Q_{x}$ e $P_{x}$ representam os níveis de preço e quantidade demandada do bem $\mathbf{x}$; DD é a curva de demanda do bem $\mathbf{x} ; \mathrm{p}_{1}$ é o preço pago pela quantidade demandada $\mathrm{q}_{1}$ do bem $\mathbf{x}$.

Essa definição de excedente do consumidor advém da teoria da demanda marshalliana, desenvolvida segundo a abordagem cardinal de utilidade.

Tweeten (1989) cita pontos críticos referentes ao excedente do consumidor. O primeiro se deve ao fato de o excedente do consumidor ser estimado a partir de uma curva de demanda que, por sua vez, é calculada a partir de informações limitadas de uma série de dados históricos sobre preços e quantidades. Segundo Tweeten (1989), as séries dos dados históricos de preço e quantidade utilizadas para estimar a 
curva de demanda podem excluir informações que levariam à estimativa de um formato da curva de demanda diferente da obtida. Isto pode prejudicar a mensuração do verdadeiro excedente do consumidor.

A segunda crítica quanto ao excedente do consumidor é que preço como medida de utilidade marginal e a área total sob a curva de demanda, à esquerda de uma dada quantidade, como medida de utilidade total desta quantidade, requerem como pressuposição de ser constante a utilidade marginal da renda.

A teoria da demanda expõe que a quantidade demandada de um bem $\mathbf{x}$ depende do preço desse bem, dos preços de outros bens (substitutos e complementares), dos gostos e preferências do consumidor, da população, da renda, enfim, de variáveis que afetam a demanda do bem $\mathbf{x}$. Contudo, ao calcular o excedente do consumidor, considera-se que todas as variáveis explicativas sejam constantes, exceto o preço do produto. Assim procedendo, pressupõe-se ser constante a utilidade marginal da renda.

A terceira crítica ao cálculo tradicional do excedente do consumidor é que a curva de demanda ordinária considera não somente o efeito substituição, mas, também, o efeito renda ${ }^{4}$. Imagine que, dado um nível de renda monetária constante, se houver uma queda no preço de um bem $\mathbf{x}$, a renda real do consumidor desse bem $\mathbf{x}$ fica maior e, em se tratando de um bem normal (ou superior), o efeito renda é positivo, fato que induz ao aumento de consumo desse bem $\mathbf{x}$.

Segundo Hicks (1984), a melhor maneira de medir o excedente do consumidor é considerá-lo como um meio de expressar, em termos de renda monetária, o ganho que o consumidor obtém em decorrência de uma queda de preço. Assim sendo, Tweeten (1989) cita que a forma ideal de estimar o excedente do consumidor é através da curva de demanda compensada de Hicks.

\footnotetext{
${ }^{4}$ A Teoria Ordinal do Comportamento do Consumidor explica que, toda vez que o preço de um bem $\mathbf{x}$ varia, a quantidade demandada deste bem também varia. Esta variação da quantidade demandada ocorre devido a dois efeitos: efeito renda e efeito substituição. O efeito renda refere-se à variação da quantidade demandada do bem $\mathbf{x}$ em virtude da variação da renda real do consumidor causada por uma variação do preço do bem $\mathbf{x}$ em questão, mantendo constante todos os ouros fatores que afetam a quantidade demandada desse bem. O efeito substituição refere-se à variação da quantidade demandada de um bem $\mathbf{x}$ em virtude da variação do preço do bem $\mathbf{x}$ em questão, mantendo constante a renda real do consumidor. A soma desses dois efeitos denomina-se efeito total ou efeito preço.
} 
Conforme Silva (1992), através da abordagem ordinal da utilidade, Hicks constrói a curva de demanda compensada. Essa curva representa a quantidade demandada de um bem qualquer a um dado nível de preço, assumindo que a renda do consumidor seja ajustada, de forma a mantê-lo na mesma curva de indiferença. Assim, a curva de demanda compensada neutraliza o efeito renda, considerando apenas o efeito substituição.

Comparando a curva de demanda original com a compensada, a diferença básica é o efeito renda. Ao considerar o efeito renda (supondo bens normais, onde o efeito renda é positivo), a curva de demanda original apresenta uma elasticidade-preço da demanda maior do que a curva de demanda compensada, o que implica diferentes magnitudes do excedente do consumidor 5 .

Conforme Fonseca (1976), o viés entre o excedente do consumidor estimado pelo uso da curva de demanda ordinária em relação ao que se obtém através do uso da curva de demanda compensada será tanto mais reduzido quanto menor for o efeito renda, ou seja, quanto menor for a elasticidade-renda da demanda ou quanto menor for a proporção do orçamento total do consumidor gasto com o bem em questão. Dessa forma, à medida que o efeito renda tende a zero, a magnitude de excedente do consumidor de Marshall se aproxima da magnitude do excedente do consumidor estimado através da curva de demanda compensada de Hicks.

Ainda no que se refere ao excedente do consumidor, Tweeten (1989) destaca os problemas de se usar a demanda agregada para medir utilidade, uma vez que utilidades marginais diferem entre indivíduos. Dessa forma, o autor aborda que, embora diferenças dentro de grupos (tais como grupo de produtores ou de consumidores) possam ser amenizadas por uma média, diferenças sistemáticas entre grupos são aparentes, através do nível de renda. Assim, análises clássicas do bem-estar se aplicam antes para grupos do que para comportamento individual.

\footnotetext{
5 À medida que a curva de demanda ordinária se mostra mais elástica que a curva de demanda compensada (no caso de um bem normal, onde a elasticidade renda é positiva), a elasticidade-preço da demanda na curva de demanda original subestima o excedente do consumidor.
} 
- Excedente do produtor

Na definição de Marshall (1982), excedente do produtor é a diferença entre o que o produtor recebe ao vender um bem e o total mínimo requerido para induzir o produtor a se desfazer do bem.

Segundo Fonseca (1976), considerando a curva de oferta de um bem definida como sendo o local dos preços mínimos aos quais um bem seria vendido, podese observar, pela Figura 3, que o excedente do produtor é representado pela área a. O excedente do produtor é a área à esquerda da curva de oferta (S) de um bem e abaixo da linha de preço desse bem $\left(p_{1}\right)$.

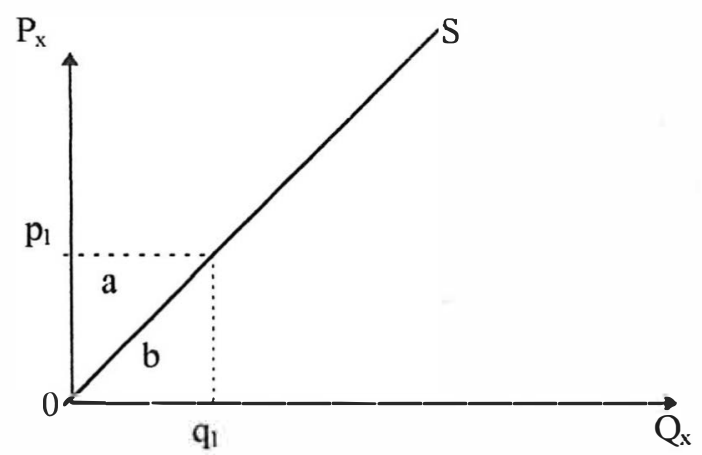

Figura 3 - Excedente do produtor (área a).

Nota: $Q_{x}$ e $P_{x}$ representam os níveis de preço e quantidade ofertada do bem $\mathbf{x}$; é a curva de oferta do bem $\mathbf{x} ; p_{1}$ é o preço recebido pela quantidade vendida $q_{1}$ do bem $\mathbf{x}$.

Segundo Mishan (1968), o termo excedente do produtor não é claro, pois pode estar se referindo tanto ao proprietário dos fatores de produção quanto ao empresário. $\mathrm{O}$ autor sugere o uso de renda econômica em vez de excedente do produtor. Assim sendo, para tornar mais claro o que a área à esquerda da curva de oferta e abaixo da linha de preço significa, são descritas algumas situações, tomando como base um mercado competitivo.

No curto prazo, a área à esquerda da curva de oferta da empresa e abaixo da linha de preço mede o excesso de receita bruta sobre os custos, sabendo-se que a 
curva de oferta coincide com a curva do custo marginal (a partir do custo variável médio mínimo).

Ao considerar uma indústria, no curto prazo, cujas empresas sejam eficientes e os preços dos fatores constantes, a área à esquerda da curva de oferta da indústria e abaixo da linha de preço mede o excedente agregado dos proprietários das empresas.

Tweeten $(1989$, p.52) tem a seguinte colocação sobre a maneira de medir o excedente do produtor:

"Excedente do produtor é um retorno a recursos fixos - um retomo líquido depois de subtrair os custos variáveis dos retomos brutos. Curvas de oferta são relações comportamentais. Elas são medidas imprecisas da renda econômica no curto e longo prazos. Freqüentemente, a melhor solução para esse problema é estimar o excedente do produtor como a receita bruta menos todos os custos operacionais, definidos como custos que são variáveis ao longo do tempo considerado".

- Modelo Especifico da Pesquisa

$\mathrm{Na}$ presente pesquisa, as críticas ressaltadas por Tweeten (1989), a respeito da maneira de mensurar o excedente do consumidor, não puderam ser consideradas na formulação do modelo. Torna-se importante ressaltar que a formulação do modelo específico pressupõe que o mesmo é uma aproximação bem definida da realidade. Assim sendo e dadas as limitações de séries de preço e quantidade do pescado brasileiro, recorre-se ao modo tradicional de estimar a curva de demanda de pescado (como fizeram os trabalhos que calcularam a relação beneficio-custo, citados anteriormente).

Outro ponto crítico a ser mencionado, refere-se à pressuposição de ser constante a utilidade marginal da renda. O presente estudo parte do pressuposto de que variações na renda do consumidor não afetam fortemente a quantidade demandada do pescado, ou seja, que a elasticidade-renda da demanda por pescado é pequena, uma vez 
que não se tem, para o Brasil, uma preferência bem definida para o pescado. Assim sendo, ao assumir a hipótese de utilidade marginal da renda como sendo constante e sendo pequeno o efeito dessa variável sobre a quantidade demandada do pescado, o cálculo do excedente do consumidor não deve sofrer diferenças significativas.

Isso posto, apresenta-se o modelo de cálculo do excedente econômico acompanhando a exposição de Bacha $(1995)^{6}$ com algumas modificações.

A partir da Figura 4 , observa-se a curva de demanda $\left(\mathrm{D}_{0} \mathrm{D}_{\mathrm{o}}\right)$ por pescado oriundo da pesca extrativa e não-extrativa e a curva de oferta do pescado $\left(\mathrm{S}_{0} \mathrm{~S}_{0}\right)$ oriundo da pesca extrativa e não-extrativa. O excedente econômico total é a soma do excedente do produtor (área $\mathrm{P}_{0} \mathrm{EAP}_{0}$ ) e do excedente do consumidor (área $\mathrm{P}_{0} \mathrm{EBP}_{0}$ ).

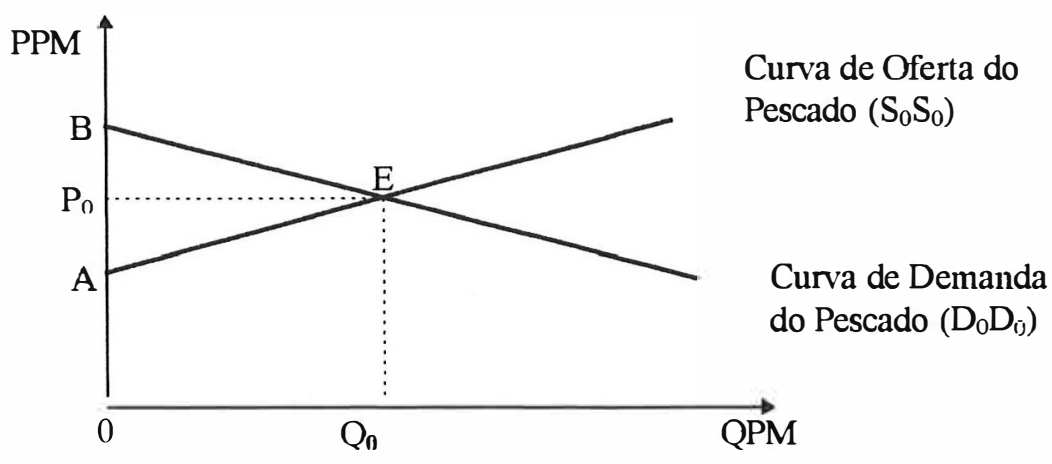

Figura 4 - Equilíbrio no mercado de pescado.

Nota: $\mathrm{QPM}=$ quantidade de pescado oriundo da pesca extrativa e não-extrativa; $\mathrm{PPM}=$ preço do pescado oriundo da pesca extrativa e não-extrativa; $\mathrm{P}_{0}=$ preço de equilíbrio do mercado por unidade de pescado; $\mathrm{Q}_{0}=$ quantidade de equilíbrio no mercado de pescado.

A concessão de incentivos fiscais à pesca tem o efeito de reduzir os custos de produção, deslocando a curva de oferta do pescado para a direita (para $S_{1} S_{1}$ nas

\footnotetext{
${ }^{\circ}$ Bacha (1995) considerou a literatura existente (em especial os trabalhos de Santana \& Khan, 1992; Lindner \& Jarret, 1978; e Rose, 1980) para adaptar um modelo de cálculo de beneficio social trazido pelos incentivos fiscais concedidos ao reflorestamento. Uma vez que incentivos físcais foram concedidos não apenas à atividade de reflorestamento mas também à atividade da pesca no Brasil; uma vez que recursos florestais e recursos pesqueiros são recursos naturais renováveis; e, uma vez que este estudo se propõe a analisar a relação benefĩcio/custo do programa de incentivos físcais à pesca, o modelo considerado por Bacha (1995) se mostra útil como referência para a estimativa do benefício social dos incentivos físcais concedidos à atividade da pesca no Brasil.
} 
Figuras 5 e 6). $\mathrm{O}$ excedente econômico será modificado conforme o tipo de deslocamento da curva de oferta de pescado.

$\mathrm{Na}$ Figura 5, tem-se o deslocamento pivotal da curva de oferta de pescado (cujo intercepto se mantém constante, no eixo vertical). O acréscimo do excedente econômico total é dado pela área EABCE.

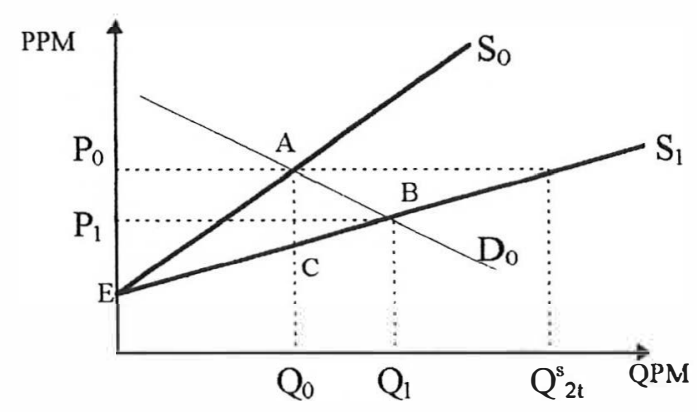

Figura 5 - Deslocamento pivotal da curva de oferta do pescado.

Nota: $S_{0}$ e $S_{1}$ representam, respectivamente, as curvas de oferta do pescado antes e após a concessão de incentivos fiscais à pesca; $\mathrm{P}_{0} \mathrm{e} \mathrm{Q}_{0}$ são, respectivamente, $\mathrm{o}$ preço e quantidade de equilíbrio do pescado antes da concessão de incentivos fiscais à pesca; $P_{1}$ e $Q_{1}$ são, respectivamente, o preço e a quantidade de equilíbrio do pescado após a concessão de incentivos fiscais à pesca.

Na Figura 6, tem-se o deslocamento paralelo da curva de oferta de pescado. O acréscimo do excedente econômico total é dado pela área EABCFE.

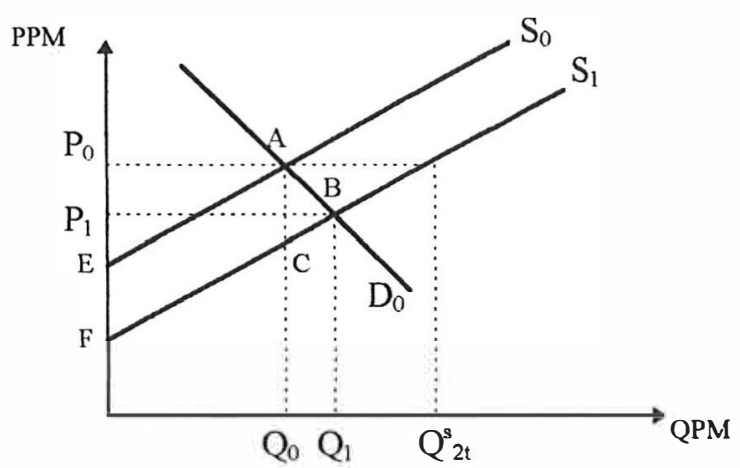

Figura 6 - Deslocamento paralelo da curva de oferta do pescado.

Nota: $S_{0}$ e $S_{1}$ representam, respectivamente, as curvas de oferta do pescado antes e após a concessão de incentivos fiscais à pesca; $\mathrm{P}_{0} \mathrm{e} \mathrm{Q}_{0}$ são, respectivamente, o preço e quantidade de equilibrio do pescado antes da concessão de incentivos fiscais à pesca; $\mathrm{P}_{1}$ e $\mathrm{Q}_{1}$ são, respectivamente, o preço e a quantidade de equilibrio do pescado após a concessão de incentivos fiscais à pesca. 
O aumento do excedente econômico é uma medida do benefício social total gerado pelos incentivos fiscais concedidos à pesca.

Para medir o Beneficio Social Total (BST), podem ser utilizadas as seguintes equações (ver a demonstração no Apêndice A):

$$
\begin{array}{cl}
\mathrm{BST}=0,5 K P_{0} Q_{0}\left(1+Z \varepsilon^{d}\right) & \text { (1) } \\
& \text { para o deslocamento pivotal da } \\
& \text { curva de oferta }
\end{array}
$$

ou

$$
\begin{array}{ll}
\mathrm{BST}=0,5 K P_{0} Q_{o}\left(2+Z \varepsilon^{d}\right) & \text { (2) } \\
& \text { para o deslocamento paralelo da } \\
& \text { curva de oferta }
\end{array}
$$

onde:

$P_{o}$ e $Q_{0}$ são o preço e a quantidade de equilíbrio do pescado oriundo da pesca extrativa e não-extrativa, respectivamente, antes da concessão de incentivos fiscais à pesca.

$\varepsilon^{d}=$ elasticidade-preço da demanda do pescado oriundo da pesca extrativa e nãoextrativa (em valores absolutos);

Segundo Rose (1980), o $Z$ é calculado pela seguinte fórmula:

$$
Z=\frac{K \cdot \varepsilon^{s}}{\left(\varepsilon^{s}+\varepsilon^{d}\right)}
$$

$\varepsilon^{s}=$ elasticidade-preço da oferta do pescado oriundo da pesca extrativa e nãoextrativa;

$K=$ é o deslocador da curva de oferta (ver Figura 5 e 6) e mede a redução proporcional dos custos, ou seja:

$$
K=\frac{\overline{A C}}{P_{0}}
$$


Tomando o ponto de coordenadas $\left(Q_{2 t}^{s}, P_{0}\right)$ na Figura 5 , tem-se que a elasticidade preço da oferta $\left(\varepsilon^{s}\right)$ é:

$$
\varepsilon^{s}=\frac{\left(\frac{Q_{2 t}^{s}-Q_{0}}{Q_{2 t}^{s}}\right)}{\left(\frac{\overline{A C}}{P_{0}}\right)} \quad \therefore \varepsilon^{s}=\frac{\left(1-\frac{Q_{0}}{Q_{2 t}^{s}}\right)}{K} \therefore K=\frac{\left(1-\frac{Q_{0}}{Q_{2 t}^{s}}\right)}{\varepsilon^{s}}
$$

A última fórmula nos diz que $K$ é medido pela mudança proporcional na produção dividida pela elasticidade-preço da oferta $\left(\varepsilon^{s}\right)$. Portanto, para estimar $K$, é necessário ter uma estimativa do produto ofertado ao preço $\mathrm{P}_{0}$ antes e após a concessão de incentivos fiscais à pesca.

Para calcular as elasticidades-preço da demanda e da oferta do pescado oriundo da pesca extrativa e não-extrativa $\left(\varepsilon^{d}\right.$ e $\varepsilon^{s}$, respectivamente), propõe-se o seguinte modelo ${ }^{7}$ :

$\mathrm{LQD} D_{t}=a_{0}+a_{1} \mathrm{LP}_{t}+a_{2} \mathrm{LPS}_{t}+a_{3} \mathrm{~L} R_{t}+a_{4} \mathrm{~L} P O P_{t}$ equação de demanda

$\mathrm{LQS}_{t}=b_{0}+b_{1} \mathrm{~L} P_{t}+b_{2} \mathrm{~L} I F_{t-k}$ equação de oferta

$\mathrm{LQD} D_{t}=\mathrm{LQS}-\mathrm{L} X_{t}$ equação de equilíbrio

onde:

$Q D_{t}=$ quantidade demandada internamente do pescado oriundo da pesca extrativa e não-extrativa no momento $\mathrm{t}$, medida em kg;

$Q S_{t}=$ quantidade ofertada do pescado oriundo da pesca extrativa e não-extrativa no momento t, medida em $\mathrm{kg}$;

\footnotetext{
${ }^{7}$ Este modelo difere basicamente do de Bacha (1995, p. 19) na equação de equilíbrio, pela inclusão da variável exportação nessa equação.
} 
$P_{t}=$ preço do pescado oriundo da pesca extrativa e não-extrativa no momento t, medido em reais deflacionados ${ }^{8}$, por $\mathrm{kg}$;

$P S_{t}=$ preço do bem substituto (da carne de boi ou de frango), no momento $t$, em reais deflacionados, por kg;

$R_{t}=$ Produto Interno Bruto no momento t, em reais deflacionados;

$P O P_{t}=$ população residente no momento t, em número de habitantes;

$I F_{t-k}=$ total de incentivos fiscais concedidos à atividade da pesca no momento $\mathrm{t}-\mathrm{k}$, medido em reais deflacionados;

$X_{t}=$ quantidade exportada do pescado no momento $\mathrm{t}, \mathrm{em} \mathrm{kg}$.

O modelo de equilíbrio descrito é constituído pelas equações de demanda (equação 6) e oferta (equação 7) de pescado, no Brasil, e da identidade entre a quantidade ofertada e demandada do pescado (equação 8 ).

$\mathrm{L}$ indica que as variáveis têm seus valores tomados em logaritmos neperianos. Assim sendo, permite obter diretamente as elasticidades-preço da demanda e da oferta do pescado no Brasil, representadas diretamente pelos coeficiente de $P_{t}$ nas equações (6) e (7), $a_{l}$ e $b_{l}$, respectivamente.

O critério adotado para construir este modelo está relacionado com fatores econômicos e estatísticos. A estrutura da demanda do pescado no Brasil é formada pelo preço do bem em questão (preço do pescado), pelo preço de um bem substituto (representado pelo preço da carne de boi ou de frango), pela renda do consumidor e pela população residente. No caso da oferta de pescado, esta é formada pelo preço do pescado e por uma política governamental de incentivos à atividade pesqueira.

A variável $\underline{Q} D_{t}$ (quantidade demandada do pescado oriundo da pesca extrativa e não-extrativa) expressa o consumo nacional aparente do pescado, ou seja,

\footnotetext{
${ }^{8}$ Os preços nominais são transtomados em reais e estes são deflacionados de modo a ter preços com poder de compra de um mês especifico (por exiemplo, agosto de 1994).
} 
$Q D_{t}$ é a quantidade produzida do pescado nacional mais a quantidade importada do pescado menos a quantidade exportada do pescado nacional.

A variável $Q S_{t}$ (quantidade ofertada do pescado oriundo da pesca extrativa e não-extrativa) expressa a oferta aparente do pescado, ou seja, $Q S_{t}$ é a quantidade produzida do pescado nacional mais a quantidade importada de pescado.

A variável $P_{t}$ (preço do pescado no momento t) é uma média ponderada dos preços dos grupos das diferentes espécies de pescado?

$$
P_{t}=\frac{\sum_{i=1}^{n} p_{i_{t}} q_{i_{t}}}{\sum_{i=1}^{n} q_{i_{t}}}
$$

onde: $p_{i_{t}}$ e $q_{i_{t}}$ representam, respectivamente, os preços e as quantidades dos diferentes grupos de pescado $[i=(1 \ldots n)$ representa o número de grupos das diferentes espécies de pescado, ou seja, sendo cinco o número de grupos de pescado, $n=5$ ], no momento t. Os preços são medidos em reais por $\mathrm{kg}$ e as quantidades medidas em $\mathrm{kg}$.

A variável $P S_{t}$ (preço do bem substituto no momento t) é representada pelo preço da carne de boi no momento $t$, em reais por $\mathrm{kg}\left(P B_{t}\right)$, ou pelo preço da carne de frango no momento $\mathrm{t}$, em reais por $\mathrm{kg}\left(P F_{t}\right)$.

Espera-se que a quantidade demandada de pescado no momento t $\left(Q D_{t}\right)$ varie inversamente em relação a flutuações do preço desse produto $\left(P_{t}\right)$, e no mesmo sentido das flutuações do preço do bem substituto $\left(P S_{t}\right)$, da renda nacional $\left(R_{t}\right)$ e da

\footnotetext{
${ }^{9}$ A classificação, neste estudo, do pescado por grupos de espécies diferenciadas é a mesma publicada no Anuário Estatístico do Brasil, de onde esses dados foram coletados. São considerados cinco grupos diferentes: peixes, crustáceos, moluscos, mamíferos aquáticos e quelônios.
} 
população residente $\left(P O P_{t}\right)$. No caso da oferta, é esperado que variações da quantidade ofertada de pescado no momento t sejam no mesmo sentido das flutuações do preço do pescado $\left(P_{t}\right)$ e dos incentivos fiscais $\left(I F_{t-k}\right)$. Dessa forma, os sinais esperados para os coeficientes são: $a_{1}<0, a_{2}>0, a_{3}>0, a_{4}>0, b_{1}>0$ e $b_{2}>0$. Sabe-se que $\varepsilon^{d}=\left|a_{1}\right|$, $\varepsilon^{s}=b_{1}$. Pode-se destacar ainda que o coeficiente da elasticidade-renda da demanda $(\eta)$ é dado por $a_{3}$.

Para efeito de ajustamento econométrico, as variáveis $Q D_{t}, Q S_{t}$ e $R_{t}$ podem ser mensuradas em seus valores agregados ou em valores per capita.

Para estimar as equações de demanda e oferta de pescado oriundo da pesca extrativa e não-extrativa [equações (6) e (7)] adota-se o método dos mínimos quadrados em dois estágios ${ }^{10}$.

O Beneficio Social Total (BST) - calculado através das equações (1) e (2) - deve ser comparado com o Custo Social Total (CST). Este último é medido pelo montante gasto com incentivos fiscais destinados à atividade pesqueira. Com isto, tem-se uma primeira avaliação benefício-custo deste tipo de instrumento de promoção à produção.

Uma outra forma de avaliar os beneficios econômicos e sociais advindos de políticas públicas, e que complementa a análise acima, é caracterizar os efeitos diretos dessas políticas sobre variáveis econômicas e sociais do País, tais como, efeitos sobre a geração de produto, geração de emprego, sobre a estrutura produtiva, isto é, variáveis que caracterizam a evolução do setor beneficiado. Bacha (1993), ao analisar a dinâmica dos processos de desmatamento e de reflorestamento no Brasil, ressalta a evolução das políticas públicas federais associadas a esses processos, avaliando os resultados obtidos por essas politicas e as implicações do reflorestamento e da extração vegetal na geração

\footnotetext{
${ }^{10} \mathrm{O}$ método de mínimos quadrados em dois estágios (MQ2E) foi escolhido com base na identificação do modelo de equações proposto neste estudo. Uma vez analisadas, tanto a equação de demanda como a equação de oferta de pescado mostraram-se superidentificadas. Assim sendo, conforme Hoffmann \& Vieira (1987, p.294) e Kmenta (1978, p.604), os parâmetros dessas equações podem ser estimados pelo método de MQ2E.
} 
de renda, de emprego e no aumento da desigualdade da distribuição da posse da terra e da riqueza.

No presente estudo, como forma de complementar a análise convencional beneficio-custo apresentada nesse capitulo, é feita uma análise da contribuição da política de incentivos fiscais à expansão do segmento industrial do Sistema Agroindustrial do Pescado, à expansão do valor da produção e do emprego na atividade pesqueira (conteúdo do capítulo 5 desse estudo).

\subsubsection{Dados da pesquisa}

Para estimar o modelo composto pelas equações (6), (7) e (8), são utilizados dados com periodicidade anual, compreendendo o período de 1960 a 1994, não obstante o período de existência dos incentivos fiscais à pesca compreender os anos de 1967 a 1986.

De forma mais detalhada, descreve-se o procedimento utilizado para construir as variáveis do modelo:

- As variáveis $Q D_{t}$ (quantidade demandada do pescado) e $Q S_{t}$ (quantidade ofertada do pescado) são construidas a partir dos dados de produção, exportação e importação do pescado, em toneladas (dados do Anuário Estatístico do Brasil - diversos números), transformados em $\mathrm{kg}$.

- A variável $P_{t}$ (preço do pescado, em $\mathrm{R} \$ / \mathrm{kg}$ ) é construída a partir da média ponderada dos preços e quantidades dos diferentes grupos de espécies de pescado, conforme classificação do Anuário Estatístico do Brasil, ou seja, peixes (arraia, cação, sardinha e outros), crustáceos (camarão, caranguejo, lagosta, siri e outros), moluscos (polvo, lula, marisco, ostra e outros), mamíferos aquáticos (baleia, peixeboi), quelônios (tartaruga, tracajá) e pescado não identificados. Foram coletados dados anuais, em valor monetário corrente e em tonelada, dos diferentes grupos de espécies de pescado produzidas no Brasil, e transformados em valor referentes a 
reais de agosto de 1994 e em produção por $\mathrm{kg}$, respectivamente. De posse desses últimos dados, montou-se uma série de dados para cada grupo, em $\mathrm{R} \$$ de agosto de 1994 por kg. A partir de então, fez-se uma média ponderada dos vários grupos de pescado, chegando à variável $P_{t}$, indicando o preço anual do pescado para o Brasil, em R\$ de agosto de 1994.

- A variável $P S_{t}$ (preço do bem substituto, em $\mathrm{R} \$ / \mathrm{kg}$ ) é representada pelo preço da carne de boi no momento t, em $\mathrm{R} \$ / \mathrm{kg}\left(P B_{t}\right)$, ou pelo preço da carne de frango no momento t, em $\mathrm{R} \$ / \mathrm{kg}\left(P F_{t}\right)$. A variável $P B_{t}$ é construída a partir de dados mensais do preço por arroba do boi gordo no Estado de São Paulo, em moeda corrente (dados do Anuário Estatístico do Instituto de Economia Agrícola - IEA/SP, diversos números), transformados em dados anuais, expressos em $\mathrm{R} \$$ de agosto de 1994 por $\mathrm{kg}$. A variável $P F_{t}$ é construída a partir de dados mensais do preço por $\mathrm{kg}$ do frango para corte no Estado de São Paulo, em moeda corrente (dados do Anuário Estatístico do Instituto de Economia Agrícola - IEA/SP, diversos números), transformados em dados anuais, expressos em $\mathrm{R} \$$ de agosto de 1994 por $\mathrm{kg}$.

- Os valores dos incentivos fiscais concedidos à atividade pesqueira $\left(I F_{t-k}\right)$ foram extraídos de uma Tabela fornecida pelo Banco do Nordeste do Brasil (BNB), com valores correntes, referentes à distribuição dos incentivos fiscais aplicados a setores e regiões. Esses valores foram transformados em R\$ de agosto de 1994.

- A variável renda nacional $\left(R_{t}\right)$ representa os valores anuais do Produto Interno Bruto a preços de mercado, retirados da Conjuntura Econômica - diversos números, expressos em R \$ de agosto de 1994.

- A variável $P O P_{t}$ significa a população residente, em número de habitantes, retirada de Anuário Estatístico do Brasil - diversos números.

Os dados utilizados para estimar as equações (6), (7) e (8) estão na Tabela 8 do capítulo 4 . 
Para avaliar a contribuição dos incentivos fiscais à pesca na expansão do segmento industrial do Sistema Agroindustrial do Pescado, na expansão do valor da produção e do emprego na atividade pesqueira faz-se uso de dados dos Censos Industriais, dos Censos Demográficos e dos Anuários Estatísticos do Brasil, complementados com informações específicas retiradas da literatura especializada (ver capítulo 5). 


\section{AS POLÍTICAS FEDERAIS RELATIVAS À PESCA E A EVOLUÇÃO DA ATIVIDADE PESQUEIRA NO BRASIL}

O presente capítulo analisa as políticas federais de regulamentação e incentivo à atividade pesqueira no Brasil, bem como analisa a evolução dessa atividade. No item 3.1, apresentam-se as politicas pesqueiras federais: a regulamentação da atividade da pesca no Brasil (sub-item 3.1.1) e o programa de incentivos federais à produção pesqueira no país (sub-item 3.1.2). Procura-se examinar como os instrumentos de regulação da atividade pesqueira, discutidos no sub-item 2.1.2, foram utilizados no Brasil.

No item 3.2, analisa-se a evolução da atividade pesqueira no Brasil, considerando a distribuição geográfica da pesca e o valor da produção pesqueira. Procura-se, neste caso, avaliar os impactos da política pesqueira federal sobre a produção do pescado e sobre a distribuição regional desta atividade.

\subsection{As políticas pesqueiras nacionais}

As políticas federais referentes à atividade da pesca no Brasil atuaram em dois sentidos: estabelecendo regulamentações à atividade pesqueira e concedendo incentivos à produção do pescado nacional.

A regulamentação da atividade pesqueira é um procedimento utilizado pelo Governo para administrar a exploração dos recursos pesqueiros de forma racional (Neiva, 1990). O incentivo à produção pesqueira é um procedimento de promoção ao desenvolvimento da atividade pesqueira. 


\subsubsection{Política regulamentadora da atividade pesqueira}

Conforme mencionado no capitulo anterior, para administrar a exploração dos recursos pesqueiros de forma racional, faz-se necessário regulamentar a atividade pesqueira (isto é, captura e venda do pescado). No presente estudo procura-se distinguir, no contexto da apresentação da política regulamentadora da atividade pesqueira no Brasil, dois tipos de regulamentações: aquelas voltadas à institucionalização de órgãos responsáveis pela coordenação da atividade pesqueira e, complementando-as, as regulamentações que instituem o ordenamento pesqueiro ${ }^{11}$

A evolução das politicas federais de regulamentação da atividade da pesca no Brasil pode ser dividida em quatro períodos, segundo a intensidade dessas políticas, seus efeitos e características ${ }^{12}$. O primeiro período começou com o aparecimento dos primeiros atos legais relacionados à atividade pesqueira (meados do século XIX) e se estendeu até o início da década de 30 do presente século; o segundo período começou em 1932 e permaneceu até setembro de 1962, durante o qual foram estabelecidas importantes regulamentações da atividade pesqueira; o terceiro período (que iniciou em outubro de 1962, com a criação da Superintendência para o Desenvolvimento da Pesca SUDEPE, e se estendeu até fevereiro de 1989) caracterizou-se por nova onda de regulamentações específicas da atividade pesqueira; e, o quarto período (que começou em março de 1989 e permanece até os dias atuais) tem como marco a criação do Instituto do Meio Ambiente e Recursos Naturais Renováveis - IBAMA, estabelecendo uma conduta diferente (das anteriormente tomadas) para conduzir a atividade pesqueira.

Durante os três primeiros períodos (que vai de meados do século XIX até fevereiro de 1989), a política federal referente à atividade pesqueira criou órgãos especificos para regulamentar essa atividade. Nesses períodos foram elaboradas

\footnotetext{
${ }^{11}$ O tenno Ordenamento Pesqueiro deve ser entendido como um conjunto harmônico de medidas que visam expandir ou restringir a atividade pesqueira, de modo a se obter sustentabilidade no uso do recurso, equilibrio do ecossistema onde ocorra a atividade, garantias de preservação do banco genético da espécie ou das espécies explotadas, e rentabilidade econômica dos empreendimentos empresariais (Ministério do Meio Ambiente, dos Recursos Hidricos e da Amazônia Legal, http://www.mma.gov.br).

${ }^{12}$ Esta divisão baseia-se em fases de desenvolvimento da indústria pesqueira no Brasil, caracterizadas por Giulietti \& Assumpção (1995).
} 
regulamentações específicas para a atividade pesqueira, pouco as vinculando com leis ambientais mais genéricas.

- Primeiro Periodo - meados do século XIX até 1932

Esse período caracterizou-se por medidas esporádicas e de pouca intensidade no que se referia a regulamentações referentes à atividade da pesca no país.

Apesar da atividade pesqueira existir desde o período colonial (Diegues, 1995), economicamente ela não representava fonte de riqueza para o poder central, o que não ocorria com outros recursos naturais, como, por exemplo, os recursos florestais e os metais preciosos. Segundo Giulietti \& Assumpção (1995), até a primeira década do século $\mathrm{XX}$ as pescarias eram primitivas e artesanais, predominando a pesca de subsistência, pouco representativa quanto ao volume capturado. Assim sendo, não havia interesse na regulamentação da atividade pesqueira.

Por conta disto, apenas no início do século atual (em 1912) o Governo criou a "Inspetoria de Pesca" para fiscalizar e monitorar a atividade pesqueira. Em 1923, através do Ministério da Marinha, foram organizados os Serviços de Pesca e Saneamento do Litoral (incluindo a matrícula dos pescadores e a organização desses em colônias cooperativas) para organizar a produção pesqueira.

A década de 30 é um marco de referência na história da política de regulamentação da atividade pesqueira do Brasil.

- Segundo Período - 1932 a setembro de 1962

A década de 30 e a primeira metade da década de quarenta caracterizaram-se pela presença de um Estado forte, com grande poder regulamentador, que definiu códigos referentes ao uso de recursos naturais renováveis. Como exemplo, foram criados Códigos para água, para floresta e, como será visto, o Código da Pesca (criado em 1938) com legislações específicas para a atividade pesqueira no País.

Apesar do segundo período em análise estender-se de 1932 a setembro de 1962, as políticas para regulamentar a atividade pesqueira foram estabelecidas, 
basicamente, nas duas primeiras décadas, estendendo seus efeitos sobre os anos seguintes.

Em 1932 criou-se a "Inspetoria de Caça e Pesca", que foi modificada para "Serviço da Caça e Pesca" e, mais tarde, passou a se chamar "Divisão de Caça e Pesca" (um órgão vinculado ao Departamento Nacional de Produção Animal do Ministério da Agricultura).

A Divisão de Caça e Pesca teve um importante papel no desenvolvimento da atividade pesqueira no País. Esse órgão investiu em pesquisa (na área de biologia marinha), em extensão (na formação de técnicos especializados em pesca e qualificação da mão-de-obra), em infra-estrutura básica de apoio à atividade pesqueira, no aumento da fiscalização, além de realizar as atividades até então estabelecidas pelos órgãos anteriores.

No final da década de 30 , dentro de um contexto de ideologia desenvolvimentista e de defesa da produção nacional, foi editado o Decreto-lei $\mathrm{n}^{\mathrm{o}}$ 291, de 23/02/38, conhecido como "Lei da Expansão da Pesca". De um lado, esse decreto viabilizou condições para a pesca nacional se autofinanciar, criando, para isso, a Caixa de Crédito da Pesca. Segundo Giulietti \& Assumpção (1995), os recursos recolhidos pela Caixa de Crédito da Pesca eram formados com a taxação de 5\% sobre a venda do pescado realizada nos entrepostos federais de pesca. Esses recursos eram reinvestidos na atividade pesqueira, através da concessão de financiamento para aquisição de equipamentos, de insumos e para instalação de pequenas plantas industriais e armazéns. Do outro lado, o Decreto-lei n 291 protegia o desenvolvimento da indústria nacional com uma taxa sobre produtos de pesca importados.

Outras regulamentações importantes fazem parte desse período: ainda em 1938 foi criado o Código da Pesca (Decreto-lei nº 794), caracterizando a forte atuação de regulamentação do Estado sobre a atividade pesqueira; em 1941 foi criada a Policlínica dos Pescadores $^{13}$ (Decreto-lei $\mathrm{n}^{\mathbf{0}}$ 3.118); e, em 1942 foi criada a Comissão Executiva da Pesca (Decreto-lei nº 5.030).

\footnotetext{
${ }^{13}$ A Policlínica dos Pescadores era um hospital, situado na cidade do Rio de Janeiro, destinado a atender os problemas de saúde especificamente dos pescadores.
} 
Conforme o Código de Pesca (aprovado pelo Decreto-lei n⿳⺈ 794/38), os serviços de pesca em todo o Brasil - inclusive a administração, direção, fiscalização técnica do pessoal e material respectivos -, a instrução especializada dos pescadores e sua organização profissional, e o desenvolvimento das empresas industriais processadoras do pescado ficavam inteiramente subordinados ao Ministério da Agricultura, através de seu órgão competente - o Serviço de Caça e Pesca do Departamento Nacional da Produção Animal. Esse Código permite o exercício da pesca por todos os brasileiros (maiores de 16 anos), mediante pagamento de uma licença anual de pesca. Cada pescador deve ter matrícula de pescador profissional registrada nas repartições competentes do Ministério da Marinha. Dessa forma, é concedido direito aos pescadores de organizarem suas cooperativas de consumo, de crédito, de produção e de outras modalidades. Ficava a cargo do Serviço de Caça e Pesca o controle nos entrepostos de pesca e fábricas de conserva de pescado, no sentido de exigir as boas condições sanitárias de suas instalações e da manipulação dos produtos. Entre outras, essas medidas caminhavam no sentido de organizar a atividade pesqueira no país. Entretanto, no que se refere à questão da proteção do recurso pesqueiro, o Código de Pesca define restrições muito gerais, tais como: proibir a pesca com redes ou aparelhos de espera que impeçam o livre trânsito das espécies da fauna aquática e proibir o uso de redes ou aparelhos de arrasto na pesca interior ou na litorânea ${ }^{14}$.

Segundo Giulietti \& Assumpção (1995), a ação da Comissão Executiva da Pesca sobre a atividade pesqueira era intervencionista. Como exemplo, destaca-se a atribuição de "organizar cooperativas de pescadores com a prerrogativa de determinar área de ação, designar e destituir as suas diretorias”. Entretanto, em meados de 1945 o Decreto-lei nº 8.526 extinguiu a Comissão Executiva da Pesca.

\footnotetext{
${ }^{14}$ Contorme Atigo $2^{\circ}$ do Decreto-lei $n^{0} 794 / 38$, quanto às águas em que é exercida, a pesca se divide em interior e maritima, sendo esta subdividida em litorânea, costeira e de alto mar. A pesca interior é a exercida em lagos, lagunas, açudes ou quaisquer depósitos de água doce, nos rios e outros cursos de água, bem como canais sem nenhuma ligação com o mar. A pesca litorânea é a exercida nos portos, baias, enseadas, lagoas, lagos e braços de mar, canais e quaisquer outras bacias de água salgada ou salobra, ainda que só comuniquem com o mar durante uma parte do ano. A pesca costeira é a exercida até a distância de 12 milhas na perpendicular da costa. A pesca de alto mar é aquela que se exerce além das águas territoriais.
} 
Conforme Diegues (1995), após a Segunda Guerra Mundial a atividade pesqueira sofreu alterações significativas, como a introdução das redes de nailon, do gelo, do motor de popa e mais tarde do motor de centro - isto é, insumos não mais fabricados pelos pescadores - entre outros métodos mais apurados de captura. Nesse contexto, o autor ressalta o surgimento, nesse mesmo período, das primeiras empresas industriais de beneficiamento de sardinha no Rio de Janeiro, bem como as primeiras empresas de captura do Estado do Rio de Janeiro.

De meados de 1945 até meados de 1961, nenhuma medida legislativa de maior impacto foi tomada visando regulamentar ou desenvolver a pesca no Brasil. Destaca-se, entretanto, o Decreto-lei no 9.022, de 26/02/1946, que baixa normas para o funcionamento da Caixa de Crédito da Pesca. Esse Decreto-lei fixa uma taxa de 3\% sobre o valor da venda do pescado nos entrepostos e postos de recepção. Conforme Giulietti \& Assumpção (1995), essa época é marcada por uma pulverização de legislações, tornando difícil a coordenação das atividades pesqueiras. Alguns exemplos são: Decreto Legislativo $\mathrm{n}^{\mathbf{0}}$ 14, de 09/03/1950, e Decreto Legislativo $\mathrm{n}^{\mathbf{o}}$ 28.524, de 18/08/50, direcionados para a regulamentação da pesca da baleia; e o Decreto $\mathrm{n}^{\mathbf{0}} 36.649$, de $22 / 12 / 54$, que aprova o regime de funcionamento do entreposto de pesca do Rio de Janeiro.

Em 28 de junho de 1961, através do Decreto-lei no 50.872, foi criado o Conselho de Desenvolvimento da Pesca (CODEPE). A criação do CODEPE surgiu da necessidade de coordenar as atividades pesqueiras relacionadas à pesquisa, planejamento e formação de recursos humanos, que se ampliaram no decorrer das décadas de 40 e 50 .

No período em análise (1932 a setembro de 1962) as regulamentações voltadas para o ordenamento pesqueiro (no sentido de estabelecer regras de acesso aos recursos pesqueiros) não foram relevantes. Na verdade, nesse período, a atenção estava voltada antes para a promoção do desenvolvimento e organização do Sistema Agroindustrial do Pescado no Brasil, uma vez que não se destacava (principalmente nas primeiras décadas) a questão da sustentabilidade do recurso pesqueiro no processo de 
captura do mesmo, dado que o volume capturado não era ameaçador à reprodução biológica dos cardumes.

- Terceiro Período - outubro de 1962 a fevereiro de 1989

Nesse período, ainda permaneceu um poder estatal concentrador no que se referia ao estabelecimento de regras para uso de recursos naturais, havendo a redefinição dos Códigos criados na década de 30. Com a filosofia de que recursos pesqueiros são de propriedade comum e de livre acesso, sendo passiveis de sobreexploração e exaustão, renovaram-se as legislações do Código da Pesca (como as legislações referentes às restrições à pesca, às zonas de pesca, a inclusão de política para o desenvolvimento da atividade pesqueira).

Durante os anos de 1963 a 1988, as atividades pesqueiras foram coordenadas pela Superintendência para o Desenvolvimento da Pesca (SUDEPE), criada em 11 de outubro de 1962, através da Lei Delegada nº 10. Esse órgão era uma autarquia ligada ao Ministério da Agricultura. A SUDEPE surgiu num contexto de proteção dos recursos naturais renováveis e de desenvolvimento das atividades voltadas à exploração dos recursos naturais renováveis.

Eram de competência e atribuições da SUDEPE muitas tarefas para desenvolver a atividade pesqueira no Brasil. Como exemplo, tem-se a elaboração e execução do Plano Nacional de Desenvolvimento Pesqueiro, a aplicação do Código de Pesca e a criação de normas referentes às atividades ligadas à pesca ou aos recursos pesqueiros (BRASIL, 1975).

Ao longo dos anos, novos Decretos relacionados à atividade pesqueira foram criados. Entre eles, destacam-se o Decreto n⿳0 58.696, de 22/06/1966, que incluiu a pesca como indústria de base ${ }^{15}$ (adquirindo o direito da atividade pesqueira ser financiada por órgãos governamentais); o Decreto-lei 221 de 1967, que concedeu incentivos fiscais à atividade da pesca, impulsionando a produção pesqueira no País (esse Decreto será

\footnotetext{
15 Define-se como "Indústria da pesca", sendo conseqüentemente declarada "indústria de base", o exercício de atividades de captura, conservação, beneficiamento, transformação ou industrialização dos seres animais ou vegetais que tenham na água seu meio natural ou mais frequente de vida (Decreto-lei no 221/67).
} 
abordado detalhadamente no item 3.1.2 deste capítulo); o Decreto no 60.401 , de 1967, que criou o Programa de Pesquisa e Desenvolvimento Pesqueiro do Brasil (PDP); o Decreto $\mathrm{n}^{\mathbf{0}}$ 63.124, de 1968, que tratou da pesquisa e exploração nas águas do mar territorial do Brasil; o Decreto nº 65.005, de 18/09/1969, que regulamentou as operações de pesca comercial, onde se dispõe sobre o Registro Geral da Pesca; e, o Decreto no 68.459 , de $01 / 04 / 1971$, que regulamentou a pesca tendo em vista o aproveitamento racional e a conservação dos recursos vivos do mar territorial brasileiro. Quando entrou em vigor esse último Decreto, foram revogados os Decretos nํำ 58.696, de 22/06/66, e no 65.005, de 18/09/69.

O Decreto no 68.459 , de 01/04/1971, fixa zonas de pesca no mar territorial brasileiro $^{16}$. Dentro das Disposições Gerais desse decreto, atribuiu-se à SUDEPE estabelecer, periodicamente, cotas de capturas em tonelagem máxima, por espécie e por zona de pesca, bem como determinar, em função das toneladas máximas estipuladas, todas as medidas que julgasse necessárias à preservação dos recursos vivos do mar, publicando, periodicamente, a relação dos equipamentos de pesca autorizados a cada tipo de operação pesqueira. Dessa forma, estavam sendo acionados alguns dos tradicionais instrumentos de administração de recursos pesqueiros visto no item 2.1.2.

No período analisado, várias são as portarias criadas pela SUDEPE regulamentando a atividade no sentido de explorar racionalmente o recurso pesqueiro. Além do controle da pesca via estabelecimento de cotas de captura (como mencionado no parágrafo anterior), foram editadas portarias limitando a pesca através da restrição de insumos (relacionadas a tamanho e tipo de redes, aparelhos modernos de captura, determinando tamanho e número de barcos), bem como portarias regulamentando estações de pescas definidas, limitando a pesca por tempo (ver LEGISLAÇÕES do IBAMA ..., 1998). Esses são dois outros instrumentos de administração de recursos pesqueiros visto no item 2.1.2.

\footnotetext{
${ }^{16}$ No Artigo $1^{\circ}$ desse Decreto são tixadas as seguintes zonas de pesca: a) interior da faixa de 100 milhas maritimas, medidas a partir da linha de baixa-mar do litoral continental brasileiro (faixa restrita às atividades pesqueiras exercidas por embarcações nacionais); b) além da zona fixada no item anterior, até o limite de 200 milhas maritimas (podendo a atividade pesqueira ser exercida por embarcações de pesca nacionais e estrangeiras, arrendadas por pessoas juridicas brasileiras com sede no Brasil).
} 
Cabe ressaltar que consta no Decreto $\mathrm{n}^{\mathrm{0}}$ 68.459/71 que a fiscalização da pesca no mar territorial brasileiro é de responsabilidade do Ministério da Marinha (realizada normalmente através do Serviço de Patrulha Costeira) e do Ministério da Agricultura (através da SUDEPE, exercida por funcionários devidamente credenciados), cabendo multas quando não cumpridas as legislações em vigor. No caso de infrações penais, que constituem crimes (por exemplo, embarcações cometendo delito de contrabando $^{17}$, o exercício da pesca com substâncias tóxicas, com dinamite e outros explosivos comuns), impõe-se a penalidade não apenas com multas, mas submentendo o infrator a punições nos termos da legislação penal vigente.

Ressalta-se, no entanto, que apesar da criação dessas medidas, a exploração do recurso pesqueiro não ocorreu de forma racional. Já no final desse período, observa-se o aparecimento de sobrepesca de algumas espécies de pescado (assunto a ser tratado nos itens seguintes desse capítulo).

A partir de 1986, destacam-se algumas regulamentações direcionadas à aqüicultura no Brasil. Como exemplo, cita-se a Resolução do CONAMA (Conselho Nacional para o Meio Ambiente) $n^{0}$ 001, de 23/01/86, que regulamenta a elaboração e a apresentação do RIMA (Relatório de Impacto Ambiental), com interesse direto para a aqüicultura, no seu Artigo 2º; e a Resolução do CONAMA nº 020, de 18/06/86, que classifica as águas segundo seus usos e estabelece as classes destinadas ao uso pela aqüicultura.

\section{- Quarto Periodo - março de 1989 até os dias atuais}

Nesse periodo, a politica federal brasileira referente aos recursos naturais mudou sua ótica. Ao observar que todos os recursos naturais se interagem, o Governo Federal deixou de criar órgãos específicos (para tratar do uso de recursos naturais

\footnotetext{
17 O Artigo 9ำ do Decreto-lei 221/67 cita que as embarcações estrangeiras somente poderão realizar atividades pesqueiras nas águas indicadas legais para a pesca. A infração a este artigo constitui delito de contrabando, podendo o poder público determinar a interdição da embarcação, seu equipamento e carga, e responsabilizar o comandante nos termos da legislação penal vigente. Esse artigo continua sendo válido no Decreto 68.459/71).
} 
específicos) e criou um órgão mais geral e legislações mais amplas. Entretanto, essas legislações não eliminaram as legislações específicas, mas procuraram interligá-las.

Através da Lei $\mathrm{n}^{\mathrm{o}}$ 7.735, de 22 de fevereiro de 1989, foi extinta a SUDEPE, passando suas atribuições e competência a serem desempenhadas pelo Instituto Brasileiro do Meio Ambiente e dos Recursos Naturais Renováveis (IBAMA), do Ministério do Meio Ambiente, dos Recursos Hídricos e da Amazônia Legal.

Compete ao IBAMA incentivar a pesquisa, a divulgação, a normatização, o controle e a fiscalização relativas ao meio ambiente e aos recursos naturais renováveis do Brasil. $\mathrm{O}$ atual modelo institucional do IBAMA centraliza suas atividades em Diretorias, como por exemplo a Diretoria de Incentivos à Pesquisa e Divulgação e a Diretoria de Controle e Fiscalização.

Compete ao IBAMA o controle e a fiscalização das medidas estabelecidas pela política de ordenamento pesqueiro. O objetivo dessa ação é fazer com que os recursos naturais pesqueiros sejam explorados racionalmente, de acordo com as normas e regulamentações estabelecidas por este órgão, para manter sua sustentabilidade.

Contudo, no IBAMA, as atividades da ex-SUDEPE foram disseminadas pelas suas várias Diretorias. Dessa forma, a análise e decisão referentes, por exemplo, a uma pesquisa sobre a atividade pesqueira são discutidas em uma Diretoria que analisa e decide projetos não apenas voltados para o desenvolvimento da atividade pesqueira, mas também para o desenvolvimento de outras atividades de competência do IBAMA.

Nesse período (em que a administração dos recursos pesqueiros está sob responsabilidade do IBAMA), as preocupações com a sustentação desses recursos se faz mais presente em nível nacional, em um contexto de preservação dos recursos naturais renováveis do Brasil e do Mundo. Assim, as regulamentações visando o ordenamento pesqueiro, aplicadas no Brasil, continuaram sendo criadas. Através de portarias do IBAMA estabeleceu-se: delimitação das estações do ano em que se permite a pesca, licenças de pesca, restrições aos equipamentos e insumo autorizados na pescaria e estabelecimento de cotas de captura. Como exemplo, algumas regulamentações (dentre as inúmeras editadas pelo IBAMA) são apresentadas a seguir: 
- Portaria $n^{0}$ 33, de 27/12/89, que concede registro e autorização a determinada embarcação pesqueira para efetuar pesca de arrasto de peixes demersais (peixes que vivem no fundo do mar) no litoral da região Sudeste/Sul, não sendo permitida a prática da pesca de sardinha e de camarões de qualquer espécie;

- Portaria n 336 , de 04/12/89, que limita o número de embarcações para a captura de sardinha nas águas territoriais do Rio de Janeiro e Santa Catarina;

- Portaria $\mathrm{n}^{\mathrm{o}} 195$, de 05/11/89, que permite a pesca de tainha e da corvina por meio do sistema de um lance para cada parelha, em São José do Norte, RS;

- Portaria n⿳⺈ 1.678 , de 31/08/90, que proíbe, a partir de 01/11/1990, o exercício da pesca com o emprego de arrastão de praia de malhas inferiores a $70 \mathrm{~mm}$, nas águas costeiras do Município de Balneário Camboriú;

- Portaria n⿳0 13, de 30/01/1992, que proíbe, anualmente, no período de 01/05 a 19/06, a pesca de camarões rosa, verdadeiro e sete barbas, na área compreendida entre as divisas dos Estados de Pernambuco e Paraíba, e Bahia e Estpírito Santo;

- Portaria nº 480, de 04/03/1991, que próibe, anualmente, a pesca do pirarucu (Arapaimagicas) na Bacia Amazônica, no período de 1/12 a 31/05.

Segundo Neiva (1990), o sistema de controle e fiscalização referente ao uso dos recursos pesqueiros, historicamente, mostrou-se deficiente. Para o autor, a imensa extensão territorial do País, a extensão da rede hidrográfica, a amplitude do mar territorial e da zona econômica de exploração, aliados à carência de recursos para aquisição de equipamentos e realização de serviços por parte dos órgãos competentes, bem como a total falta de pessoal treinado para a atividade e a ação corrupta que permeava a atividade, tornaram a fiscalização pesqueira completamente ineficiente. Entretanto, o autor reconhece uma melhoria na execução do controle e fiscalização a partir da criação do IBAMA. Essa melhoria se justifica pela unificação do pessoal e das competências, antes difundidas em vários órgãos (como SUDEPE, IBDF, entre outros), para o controle e fiscalização do meio ambiente e dos recursos naturais renováveis. 
De acordo com LINHAS de atuação ... (1998) ${ }^{18}$, o sistema de fiscalização do IBAMA ganhou em qualidade com a utilização de novas tecnologias como o sensoriamento remoto, imagens de satélites, localização georeferenciada e sensores aerotransportados, fazendo com que as ações sejam planejadas com antecedência e direcionadas aos locais detectados por esses instrumentos. Juntamente com essa ação, tem-se também a implementação de uma política de fiscalização mais educativa e menos punitiva. Dentre as ações especiais de fiscalização na área da pesca, tem-se: combate à pesca predatória (principalmente nos períodos dos defesos ${ }^{19}$ das espécies controladas) nos lagos, açudes públicos e reservatórios federais, através da presença permanente dos agentes de defesa ambiental nos locais de captura, desembarque e comércio de pescado; fiscalização e combate à atividade pesqueira da frota marginal (sem autorização e/ou registro).

Não obstante, faltava ao Brasil legislação mais efetiva para punir os infratores e degradadores do meio ambiente. Segundo Martins (1997), o poder público não conseguia impor uma política de proteção ambiental eficiente por falta de amparo legal. Conforme o autor, as leis ordinárias em vigor para punir infratores e degradadores do meio ambiente são, em sua maioria, inócuas e obsoletas, seja por falta de previsão para determinados comportamentos danosos, seja por estabelecer penas ora demasiadamente severas ora leves demais. Os instrumentos legais (como o Código de Pesca, no caso da atividade pesqueira) tratam da questão ambiental de forma pontual e dissociada, não considerando o meio ambiente como um todo (solo, flora, fauna, ar, água e, principalmente, o homem).

Surge, nesse contexto, como iniciativa do IBAMA, o Projeto de Lei de Crimes Ambientais, que iniciou seu trâmite nas instâncias legais em 1991, sendo sancionada em 1998 (Lei nº 9.605, de 12 de fevereiro de 1998).

No geral, a Lei de Crimes Ambientais introduz maior clareza na individualização da responsabilidade criminal. Prevê o estabelecimento de penas

\footnotetext{
${ }^{18}$ Essa citação, da forma apresentada, refere-se a uma informação retirada de um endereço eletrônico, conforme citada na parte de "Referências bibliográticas", nessa tese.

${ }^{19}$ Refere-se ao periodo de reprodução das espécies.
} 
alternativas à prisão, tais como: prestação de serviços à comunidade; interdição temporária de direitos; suspensão parcial ou total de atividade; prestação pecuniária; e recolhimento domiciliar.

Para o caso específico da pesca, os crimes considerados pela Lei de Crimes Ambientais, bem como a pena estabelecida por tais infrações ${ }^{20}$, são:

- Pescar em período no qual a pesca seja proibida ou em lugares interditados por órgão competente; pescar espécies que devam ser preservadas ou espécimes com tamanhos inferiores aos permitidos; pescar quantidades superiores às permitidas, ou mediante a utilização de aparelhos, petrechos, técnicas e métodos não permitidos; transportar, comercializar, beneficiar ou industrializar espécimes provenientes da coleta, apanha e pesca proibidas. A pena para tais infrações é de detenção de um ano a três anos ou multa, ou ambas as penas cumulativamente.

- Pescar mediante a utilização de explosivos ou substâncias que, em contato com a água, produzam efeito semelhante; pescar mediante a utilização de substâncias tóxicas, ou outro meio proibido pela autoridade competente. A pena nestes casos compreende a reclusão de um a cinco anos.

Ainda nesse período, destacam-se as regulamentações que dão importância à atividade de aqüicultura, como:

- Portaria do IBAMA n 091 , de 03/07/93, que cria a Comissão de Licenciamento Ambiental para os projetos de Salmonicultura da Área de Proteção Ambiental e Serra da Mantiqueira.

- Portaria $n^{0}$ 095, de 03/08/93, que estabelece normas para o registro de aquicultor junto ao IBAMA. Este cadastramento é muito importante como ponto de partida para obtenção de dados estatísticos da produção da aqüicultura brasileira.

- Decreto $\mathrm{n}^{0} 1.694 / 95$, que é direcionado basicamente para a organização da atividade da pesca e aqüicultura. Esse Decreto cria o Sistema Nacional de Informações da

\footnotetext{
${ }^{20}$ A Lei de Crimes Ambientais considera pesca todo ato tendente a retirar, extrair, coletar, apanhar, apreender ou capturar espécimes dos grupos dos peixes, crustáceos, moluscos e vegetais hidróbios, suscetíveis ou não de aproveitamento econômico, ressalvadas as espécies ameaçadas de extinção, constantes nas listas oficiais da fauna e da flora.
} 
Pesca e Aqüicultura - Sinpesq, com objetivo de coletar, agregar, processar, analisar, intercambiar e disseminar as informações sobre o setor pesqueiro nacional, ficando a cargo da Fundação Instituto Brasileiro de Geografia e Estatística a coordenação da implantação, do desenvolvimento e da manutenção do Sinpesq.

- Decreto $\mathrm{n}^{0}$ 1.695/95, que regulamenta a exploração de aqüicultura em águas públicas pertencentes à União, atribuindo ao IBAMA a tarefa de fazer o registro dos aqüicultores, incluindo neste registro projeto que contenha, entre outros requisitos, o controle sanitário dos organismos a serem cultivados e o monitoramento periódico da qualidade da água na área de influência do empreendimento. Destaca-se, neste Decreto, a exigência da definição das espécies a serem cultivadas, bem como as técnicas ou equipamentos a serem utilizados nos empreendimentos de cultivos de pescado.

Observa-se, com essas regulamentações, a maior atenção dispensada à atividade da aqüicultura nos últimos anos, com regulamentações dando condições de desenvolver essa atividade de forma organizada.

Torna-se importante ressaltar que, com a Medida Provisória n⿳0 1.549-35 de 09 de outubro de 1997, a produção e fomento das atividades pesqueiras são de competência do Ministério da Agricultura e do Abastecimento, enquanto a preservação, conservação e uso racional dos recursos naturais renováveis (no caso, o recurso pesqueiro) compete ao Ministério do Meio Ambiente, dos Recursos Hídricos e da Amazônia Legal.

O exame das políticas reguladoras da pesca, acima colocados, confirmam, em parte, a hipótese formulada na introdução desta tese. O Governo Federal pouco se ateve à questão dos estoques de pescado. Apenas com a criação do IBAMA em 1989 e, com mais força, a partir de meados da década de 90 há maior rigor no controle da pesca extrativa e o incentivo à criação de pescado. Contudo, isto se deve à redução dos estoques de certas espécies de pescado, que vem conduzindo à queda da produção nacional de pescado (assunto a ser tratado no item 3.2). 
De outro lado, enquanto existiram amplos cardumes de pescado, o Governo Federal instituiu incentivos à captura, processamento e comercialização dos mesmos.

\subsubsection{Os incentivos federais à produção pesqueira no Brasil}

A partir da década de 50, o Governo Federal estabeleceu uma política de incentivos fiscais para promover o desenvolvimento regional e/ou setorial no Brasil. Esta política seguiu uma orientação geral, com peculiaridades específicas para regiões e setores.

O incentivo fiscal é uma dedução fiscal do imposto de renda devido. A dedução fiscal consiste na redução da arrecadação potencial do imposto de renda devido, que é apurado em certas atividades, desde que o recurso originado desta dedução seja aplicado em setores ou regiões específicos (Bacha, 1995). Assim sendo, o incentivo fiscal constitui um beneficio fiscal, visando a formação de capital para investimentos específicos.

Foram concedidos incentivos fiscais às atividades que levassem ao desenvolvimento do Nordeste, ao desenvolvimento da Amazônia, para empreendimentos florestais, para o desenvolvimento do turismo, para empreendimentos pesqueiros, à Empresa Brasileira de Aeronáutica (EMBRAER), à alfabetização e para o desenvolvimento do Estado do Espírito Santo. Não obstante, ocorreram diferenças na estrutura de concessão dos incentivos fiscais concedidos às regiões e setores e nos tipos de incentivos concedidos às distintas regiões e setores (ver Bacha, 1995).

Neste item, abordam-se os beneficios fiscais (incentivos e isenções) concedidos à atividade pesqueira no Brasil ${ }^{21}$ (sub-item 3.1.2.1); comenta-se a criação do Fundo de Investimentos Setorial para o setor pesqueiro (FISET/Pesca), destacando sua avaliação pela Comissão de Avaliação de Incentivos Fiscais, COMIF (sub-item 3.1.2.2); e

\footnotetext{
$\because$ Além dos benetĩcios tiscais (isenções e incentivos tíscais) à pesca, houve a concessão, em pequeno volume, de crédito subsidiado, via Sistema Nacional de Crédito Rural e Banco Nacional de Desenvolvimento Econômico e Social, para custeio, investimento e comercialização do pescado.
} 
faz-se uma avaliação dos recursos concedidos (via incentivos fiscais) aos empreendimentos pesqueiros, comparando-os com os recursos concedidos (via incentivos fiscais) ao desenvolvimento do turismo e do reflorestamento (sub-item 3.1.2.3).

\subsubsection{Os benefícios fiscais concedidos à atividade pesqueira no Brasil}

Em 28 de fevereiro de 1967 foi promulgado o Decreto-lei 221, que permitiu às pessoas jurídicas fazerem deduções tributárias para investimentos em projetos pesqueiros (os chamados "incentivos fiscais da pesca") e a isenção do imposto de importação e do imposto de renda às atividades vinculadas à pesca. Esse Decreto-lei concedeu incentivos e isenções fiscais à pesca até o ano de 1972. Tais incentivos e isenções foram:

- isenção de impostos e taxas federais (impostos sobre produtos importados, impostos sobre produtos industrializados, taxas aduaneiras, por exemplo) para a importação de máquinas, equipamentos e instrumentos em geral para a captura, industrialização, transporte e comercialização do pescado (artigos 73 e 74 do mencionado Decretolei).

- isenção do imposto sobre a renda obtida em atividades pesqueiras (artigo 80); o valor da isenção deveria ser incorporado ao capital da pessoa jurídica beneficiada até o final do exercício financeiro posterior ao da sua concessão.

- direito às pessoas jurídicas registradas no País de deduzirem do imposto de renda o máximo de $25 \%$ do valor do imposto devido, desde que os recursos fossem para inversão em projetos de atividades pesqueiras (incluindo captura, industrialização, transporte e comercialização de pescado) aprovados pela SUDEPE (artigo 81). Os beneficios desta dedução tributária somente poderiam ser concedidos se a pessoa jurídica beneficiária aplicasse recursos próprios nunca inferiores a $1 / 3$ do montante dos recursos oriundos dos incentivos fiscais.

O prazo de validade dos beneficios fiscais concedidos à pesca (pelo Decreto-lei 221 de 28/02/67) foi ampliado para o período de 1973 a 1977 através do 
Decreto-lei $\mathrm{n}^{\mathrm{o}}$ 1.217, de 09/05/72. Posteriormente, conforme Neiva (1990), os beneficios fiscais concedidos à pesca foram prorrogados, em bloco, até o ano de 1981. A partir de então, o incentivo que autorizava as pessoas jurídicas a investirem um percentual do seu imposto de renda devido em projetos aprovados pela então SUDEPE foi prorrogado até o ano de 1986 (agora não mais até $25 \%$ do imposto de renda devido, mas até $12,5 \%$ ) e o beneficio que conferia isenção do imposto de renda para projetos aprovados pela então SUDEPE foi prorrogado até 1989.

Em 1988, foi concedido beneficio fiscal ao desenvolvimento da atividade pesqueira através de isenção fiscal na aquisição do óleo diesel. Tal estímulo permitia ao usuário requisitar quota anual desse produto ao Conselho Nacional do Petróleo (CNP). Segundo Neiva (1990), em 1988 foram liberados $69.000 \mathrm{~m}^{3}$ de óleo diesel, sendo as necessidades de 1989 estimadas em $100.000 \mathrm{~m}^{3}$.

O óleo diesel é um insumo crucial na atividade da pesca. Conforme Neiva (1990), esse insumo é responsável por 20 a $40 \%$ dos custos das pescarias e, no Brasil, comparativamente a outros países, seu preço apresentava-se, de modo geral, elevado. Por exemplo, em 1988, enquanto no Brasil o preço do $\mathrm{m}^{3}$ de óleo diesel era de US\$227, nos E.U.A. era de US\$144, no Japão, US\$165 e na Costa do Marfim US\$161.

Giulietti \& Assumpção (1995) ressaltam ainda que, pelo fato da pesca atualmente estar sendo realizada mais distante do litoral (devido ao problema da escassez dos recursos pesqueiros), o elevado custo do óleo diesel agrava ainda mais o custo de produção do pescado, onerando-o, pela necessidade de mais gastos com combustível ao percorrer maior distância para pescar.

Devido à persistência da alta participação do óleo diesel no custo de produção do pescado nacional, em 30/08/96 o Poder Executivo editou a Medida Provisória $\mathrm{n}^{\mathrm{0}} 1.577$, que concede subvenção econômica ao preço do óleo diesel consumido por embarcações pesqueiras nacionais. Não obstante, o problema do diferencial entre preços pagos por embarcações nacionais e estrangeiras por óleo diesel ainda permaneceu expressivo. 
Em 1997 o Governo baixou uma medida provisória que concede subsídio ao óleo diesel utilizado pelas embarcações pesqueiras nacionais, localizadas em Estados que concederem isenção do Imposto sobre Circulação de Mercadorias e Serviços (ICMS) ao óleo. Conforme Araí (1997), até novembro de 1997, os Estados do Amazonas, Amapá, Ceará, Pará e Rio Grande do Norte já haviam viabilizado a isenção do ICMS. Essa política, equalizando o preço nacional do óleo diesel ao preço internacional, representa, segundo a diretoria do Conselho Nacional de Entidades da Pesca e da Federação dos Sindicatos e Associações de Produtores e Distribuidores de Pescado no Brasil (Conep-Fapesc), a primeira grande vitória do segmento da pesca industrial.

\subsubsection{O FISET/Pesca e sua avaliação pela COMIF}

De 1961 a 1973, através de atos normativos distintos (leis, decretos-lei e decretos), foram regulamentadas as concessões dos incentivos fiscais, de forma específica, para cada região ou setor beneficiado. Durante esse período, não havia controle centralizado da alocação desses incentivos fiscais (veja a sistemática da alocação dos incentivos fiscais em Bacha, 1995, p.37).

Comenta esse autor que o sistema de concessão de incentivos fiscais para o desenvolvimento regional e setorial, na forma como se encontrava regulamentado no período de 1961 a 1973 (por atos normativos distintos para cada região ou setor), evidenciava um excesso de demanda sobre a oferta de incentivos. Esse desequilibrio no mercado de incentivos fiscais causava duas sérias distorções:

"atrasos na execução de investimento devido a escassez de recursos e a cobrança de exageradas comissões de corretagem e de captação de incentivos fiscais"(Bacha, 1995, p.40).

A resposta do Governo Federal veio com a promulgação do Decreto-lei n⿳0 1.376 , de 12/12/74, que visava eliminar os pontos negativos acima mencionados.

Esse Decreto-lei criou o Fundo de Investimento do Nordeste (FINOR), o Fundo de Investimento da Amazônia (FINAM), e os Fundos de Investimentos Setoriais 
para o setor florestal (FISET/Florestamento-Reflorestamento), para o setor de pesca (FISET/Pesca) e para o setor de turismo (FISET/Turismo). Os fundos de investimentos foram a forma encontrada pelo Governo Federal para controlar a alocação dos recursos dos incentivos fiscais de maneira mais centralizada e, também, tentar corrigir o desequilíbrio no mercado de incentivos fiscais.

Para o caso específico dos incentivos voltados para os empreendimentos pesqueiros, o FISET/Pesca era supervisionado pela Superintendência do Desenvolvimento da Pesca (SUDEPE) e tinha como agente financeiro o Banco do Brasil S/A.

Durante uma década, volumosos recursos foram alocados a esses fundos e muitas denúncias de mal uso e desvio surgiram. Com isso, em 1985, com o objetivo de avaliar, econômica e financeiramente, os Fundos de Investimentos Setoriais e Regionais, foi criada a Comissão de Avaliação de Incentivos Fiscais (COMIF).

Em 1986, a COMIF apresentou um relatório de avaliação dos incentivos fiscais regidos pelo Decreto-lei $\mathrm{n}^{\mathbf{0}}$ 1.376, de 12/12/74. Para o caso específico do FISET/Pesca, alguns resultados relatados foram:

a) a avaliação das empresas incentivadas pelo Decreto-lei 221/67 mostrou resultado negativo: "dos 137 projetos aprovados, 21 não chegaram a fazer uso dos incentivos, 52 deixaram de obter liberações e dos 64 restantes, a maioria apresentava uma situação financeira muito precária" (IPEA/COMIF, 1986).

b) a maior parte dos projetos aprovados pela SUDEPE (após instauração dos Fundos de Investimentos Setoriais e Regionais) era de saneamento financeiro das empresas beneficiadas com os incentivos fiscais (concedidos pelo Decreto $n^{\circ} 221 / 67$ ).

c) a prioridade (dada pela SUDEPE) ao saneamento financeiro das empresas incentivadas não resolveu a situação financeira dessas. Muitas empresas entraram em situação de concordata, ficaram paralisadas, desativadas, autuadas pelo órgão ou mudaram seus objetivos sociais.

d) passada a fase de saneamento financeiro das empresas, a prioridade foi dada a projetos que visavam o aumento da produção e exportação. De todas as empresas 
beneficiadas, a maior parte (cerca de $82 \%$ ) enfrentou dificuldades devido a escassez de matérias-primas e preços internacionais desfavoráveis.

e) foram identificadas ineficiências com relação à administração do FISET/Pesca. Dentre essas ineficiências, foi observado o problema de desvio de recursos para aplicações em negócios diferentes daquele previsto no projeto aprovado, bem como a não aplicação da contrapartida de recursos próprios aos projetos aprovados para receberem incentivos fiscais.

f) a COMIF criticou a SUDEPE por atuar mais como uma agência repassadora de recursos do que como uma agência de desenvolvimento e, mesmo na função de repassadora de recursos, seu desempenho se mostrou muito precário no que se referia à análise e fiscalização dos projetos e à vigilância quanto a correta aplicação dos recursos.

A reação a esses resultados (revelados pela COMIF) veio no mesmo ano de 1986, através do Decreto n⿳0 93.607. Elaborou-se uma nova sistemática de concessão de incentivos fiscais voltados para o desenvolvimento regional e setorial. No referente aos incentivos fiscais à atividade pesqueira, destacaram-se medidas mais rígidas na fiscalização do uso dos recursos dos incentivos fiscais, maior rigor na fiscalização do uso de recursos próprios em projetos beneficiados com incentivos e aumento do uso desses recursos próprios nesses projetos.

\subsubsection{Evolução dos incentivos fiscais concedidos a empreendimentos pesqueiros.}

O volume de incentivos fiscais recebido pelos empreendimentos pesqueiros, no período de 1967 a 1986, foi de $\mathrm{R} \$ 1.015,8$ milhões de reais, a preços de agosto de 1994 (Tabela 1). Desse total, $\mathrm{R} \$ 793,5$ milhões de reais (78\%) referiam-se a recursos de incentivos fiscais destinados a empreendimentos pesqueiros no período de 1967 a 1974 (período que marca o início dos incentivos fiscais à atividade pesqueira, pelo Decreto-Lei no 221/67 e sua prorrogação pelo Decreto-Lei no 1.217/72), enquanto apenas $\mathrm{R} \$ 222,3$ milhões de reais $(22 \%)$ referiam-se a recursos captados pelos 
empreendimentos pesqueiros no período de 1975 a 1986 (período de vigência do Fundo de Investimento Setorial para a Pesca - FISET/Pesca).

Analisando os dados a partir de 1975 (ano em que começou a ter efeito o Decreto-lei no 1.376, de 12 de dezembro de 1974, que criou os fundos de investimentos regionais e setoriais), constata-se que o FISET/Pesca foi o fundo de menor participação nos recursos dos incentivos fiscais destinados a setores: de 1975 a 1986, os empreendimentos pesqueiros captaram $\mathrm{R} \$ 222,3$ milhões de reais (cerca de $\mathrm{R} \$ 18,5$ milhões de reais ao ano) via incentivos fiscais, enquanto os empreendimentos de turismo captaram $\mathrm{R} \$ 460,12$ milhões de reais (cerca de $\mathrm{R} \$ 38,34$ milhões de reais ao ano) e as atividades de reflorestamento captaram $\mathrm{R} \$ 7.193,62$ milhões de reais (cerca de $\mathrm{R} \$ 599,5$ milhões de reais ao ano).

Tabela 1: Recursos setoriais captados, via incentivos fiscais, pelas respectivas áreas de aplicação, de 1967 a 1986. em mil reais de agosto de 1994.

\begin{tabular}{lccc}
\hline ANO & PESCA & TURISMO & FLORESTA \\
\hline 1967 & $16.072,32$ & $50.311,22$ & $15.812,10$ \\
1968 & $61.810,93$ & $57.434,51$ & $55.041,40$ \\
1969 & $180.679,39$ & $62.180,06$ & $105.304,94$ \\
1970 & $213.618,60$ & $57.536,95$ & $28.351,54$ \\
1971 & $138.422,25$ & $54.021,23$ & $283.611,48$ \\
1972 & $78.188,63$ & $69.892,40$ & $348.224,98$ \\
1973 & $64.325,75$ & $74.497,59$ & 429.682 .88 \\
1974 & $40.372,88$ & $51.477,34$ & $389.047,09$ \\
1975 & $43.561,25$ & $64.390,24$ & $683.813,74$ \\
1976 & 34.325 .72 & $44.606,89$ & $818.601,75$ \\
1977 & $29.675,71$ & $39.412,62$ & $976.168,59$ \\
1978 & $24.616,07$ & $64.284,15$ & $1.178 .426,37$ \\
1979 & $23.495,15$ & $38.111,50$ & $671.965,98$ \\
1980 & $13.866,65$ & 28.349 .07 & $585.118,29$ \\
1981 & $11.855,44$ & $25.892,46$ & $554.060,54$ \\
1982 & $9.201,71$ & $19.909,50$ & $409.913,68$ \\
1983 & $10.929,97$ & $14.760,46$ & $298.600,17$ \\
1984 & 8.178 .09 & $11.028,11$ & $278.224,92$ \\
1985 & $6.707,68$ & $57.896,72$ & $349.683,03$ \\
1986 & $5.921,25$ & 5 &
\end{tabular}

Fonte: Dados fornecidos pelo Banco do Nordeste do Brasil (BNB). Os dados originais estão em cruzeiros correntes. Para transformar os valores fornecidos em valores deflacionados, utilizou-se o IGP-DI de agosto de 1994=100. 
Segundo IPEA/COMIF (1986), essa reduzida participação relativa do FISET/Pesca na captação de recursos através de incentivos fiscais se deveu, em grande parte, à falta de um plano de desenvolvimento para a atividade pesqueira (desde a promulgação do Decreto-lei 221/67), que orientasse a alocação dos recursos. A falta desse plano de desenvolvimento ocasionou (durante o período de 1967 a 1974) várias distorções no desenvolvimento da atividade (distorções advindas da falta de investimento em pesquisa, em tecnologia apropriada, da ineficiente fiscalização, da falta de treinamento do pessoal, desvios de recursos para negócios diferentes dos previstos no projeto proposto e aprovado pela SUDEPE, etc.) que, somadas aos problemas conjunturais, como aumento do preço do petróleo e dificuldades para comercialização do pescado no mercado externo, fizeram com que as perspectivas de investimentos posteriores se mostrassem bastante negativas.

É importante destacar que, durante o período de 1967 a 1972, dos R $\$ 688,8$ milhões de reais advindos de recursos captados via incentivos fiscais à pesca, a preços de agosto de 1994 , cerca de $51 \%$ foram investidos na indústria, $20 \%$ na captura, $13 \%$ na administração e apenas $7 \%$ na comercialização, sendo que na pesquisa e levantamento de dados sobre estoques pesqueiros nada foi investido (Giulietti \& Assumpção, 1995) 22

No período de 1974 a 1986, não obstante o mal uso dos recursos dos incentivos fiscais, constata-se que os mesmos destinaram-se a financiar investimentos para aumentar a produção e exportação de pescado. Também, não foram observados, nesse período, investimentos em pesquisas e estudos que pudessem permitir a exploração dos recursos pesqueiros de forma sutentável. Pelo contrário, esses recursos foram expostos à exaustão.

Esses dados confirmam, em parte, a hipótese levantada no capítulo introdutório, onde se ressaltou que a política federal pesqueira preocupou-se com a captura, o processamento e a comercialização do pescado, mas pouco se ateve à questão do estoque de pescado.

\footnotetext{
:2 Observa-se nessa citação que a soma das percentagens dá $91 \%$. Não há referência. no texto citado. sobre onde foram aplicados os $9 \%$ restantes.
} 
Não obstante, os recursos financeiros, oriundos dos incentivos fiscais à pesca, possibilitaram modificações importantes na atividade pesqueira no Brasil. Conforme Neiva (1990), a política de incentivo a empreendimentos pesqueiros impulsionou a industrialização do pescado, propiciando o surgimento de um parque industrial de qualidade, contribuindo para aumentar a produção e, conseqüentemente, a exportação de pescado fino (camarão, lagosta, etc.).

Examina-se, a seguir, como as políticas federais de regulamentação e de incentivo à produção, acima examinadas, afetaram a atividade pesqueira no Brasil.

\subsection{A evolução da atividade pesqueira no Brasil}

Para analisar a evolução da atividade pesqueira no Brasil, dividiu-se esse item em quatro partes: na primeira parte é analisada a evolução da produção do pescado no Brasil (sub-item 3.2.1); na segunda parte é feita uma análise comparativa entre a produção pesqueira marítima e a de água doce (sub-item 3.2.2); na terceira parte é elaborada uma análise da produção regional do pescado no Brasil (sub-item 3.2.3); e na quarta parte examina-se as transações externas com pescado e o consumo aparente deste produto (sub-item 3.2.4).

Procura-se destacar que após um grande crescimento na produção pesqueira nacional, esta encontra-se em nível acima do máximo rendimento sustentável, gerando sobrepesca.

\subsubsection{A evolução da produção}

A produção brasileira de pescado teve grande elevação entre 1960 e 1994 passando de 281.512 toneladas para 697.577 toneladas, respectivamente (veja Tabela 2 e Figura 7). Não obstante, essa produção apresenta um comportamento oscilatório, definindo duas tendências. De 1960 a 1985 a produção tendeu a crescer, apresentando tendência de baixa a partir de 1986 . Um primeiro salto na produção brasileira de pescado ocorreu de 1960 a 1962, permanecendo a produção de pescado relativamente estável 
entre 1963 e 1967. Nova fase ascendente na produção ocorreu entre 1968 e 1974, acompanhada de oscilações, sem tendência definida, de 1975 a 1982. Uma terceira fase de expansão da produção de pescado ocorreu de 1983 a 1985. No período de 1986 a 1990 houve forte queda na produção de pescado. Na primeira metade da década de 90 essa produção apresentou ligeira tendência de alta, mas mantendo-se abaixo da média anual obtida na segunda metade de década de 80 .

Tabela 2: Produção, exportação, importação e consumo aparente do pescado no Brasil - 1960 a 1994.

\begin{tabular}{|c|c|c|c|c|c|c|}
\hline \multirow[b]{2}{*}{ Anos } & \multirow{2}{*}{$\begin{array}{l}\text { Produção } \\
\text { toneladas } \\
\end{array}$} & \multicolumn{2}{|c|}{ Exportação } & \multicolumn{2}{|c|}{ Importação } & \multirow{2}{*}{$\begin{array}{c}\text { Cons. aparente } \\
(M+Y)-X \\
\text { toneladas }\end{array}$} \\
\hline & & toneladas & US\$/ion. & toneladas & US\$nton. & \\
\hline 1960 & 281.512 & 1.206 & n.d. ${ }^{a}$ & n.d. & n.d. & 280.306 \\
\hline 1961 & 330.140 & 1.841 & n.d. & n.d. & n.d. & 328.299 \\
\hline 1962 & 414.640 & 2.074 & n.d. & n.d. & n.d. & 412.566 \\
\hline 1953 & 421.356 & 1.801 & n.d. & n.d. & n.d. & 419.555 \\
\hline 1964 & 377.008 & 1.819 & n.d. & 21.810 & n.d. & 396.999 \\
\hline 1965 & 422.289 & 2.438 & n.d. & 16.730 & n.d. & 436.581 \\
\hline 1966 & 435.787 & 2.968 & n.d. & 28.798 & n.d. & 461.617 \\
\hline 1967 & 429.422 & 3.369 & n.d. & 38.847 & n.d. & 464.900 \\
\hline 1968 & 500.387 & 6.084 & n.d. & 44.969 & n.d. & 539.272 \\
\hline 1969 & 501.197 & 9.361 & n.d. & 51.070 & n.d. & 542.906 \\
\hline 1970 & 526.292 & 10.134 & 5808,29 & 54.477 & 1734,19 & $570 . \widetilde{35}$ \\
\hline 1971 & 591.543 & 11.392 & 7135,94 & 39.505 & 2118,65 & 619.656 \\
\hline 1972 & 604.673 & 17.422 & 6451,64 & 34.792 & 2423,01 & 622.043 \\
\hline 1973 & 698.802 & 12.552 & 650,51 & 56.978 & 2199,76 & 743.228 \\
\hline 1974 & 815.720 & 13.732 & 7250,43 & 46.355 & 2382,41 & 848.343 \\
\hline 1975 & 759.792 & 14.857 & 5533,73 & 99.469 & 985,84 & 844.404 \\
\hline 1976 & 658.847 & 13.768 & 7325,97 & 76.933 & 857,74 & 722.012 \\
\hline 1977 & 752.607 & 24.205 & 5377,59 & 61.851 & 1276,36 & 790.253 \\
\hline 1978 & 806.328 & 26.418 & 5743,78 & 62.036 & 1568,77 & 841.946 \\
\hline 1979 & 858.183 & 27.497 & 7573,05 & 89.558 & 1481,46 & 920.244 \\
\hline 1980 & 822.677 & 34.462 & 4805,60 & 66.800 & 1455,49 & 855.015 \\
\hline 1981 & 833.164 & 45.110 & 3924,68 & 45.391 & 1426,03 & 833.445 \\
\hline 1982 & 833.933 & 45.843 & 4022,04 & 56.515 & 1274,38 & 844.605 \\
\hline 1983 & 880.969 & 47.366 & 3218,50 & 41.506 & 975,36 & 875.109 \\
\hline 1984 & 958.908 & 36.986 & 5266,19 & 31.639 & 1107,85 & 953.561 \\
\hline 1985 & 971.537 & 53.250 & 3613,88 & 36.223 & 1218,06 & 954.510 \\
\hline 1986 & 941.712 & 42.551 & 4093,87 & 97.817 & 1484,55 & 996.978 \\
\hline 1987 & 934.408 & 40.978 & 4872,55 & 105.342 & 1261,00 & 998.772 \\
\hline 1988 & 830.102 & 43.571 & 4524,25 & 61.552 & 1298,36 & 848.083 \\
\hline 1989 & 798.638 & 44.354 & 2940,95 & 126.426 & 1283,51 & 880.710 \\
\hline 1990 & ๔33.599 & 34.765 & 4003,37 & 214.190 & 936,41 & 813.024 \\
\hline 1991 & 669.149 & 45.239 & 3403,28 & 159.228 & 1079,59 & 783.138 \\
\hline 1992 & 665.786 & 55.237 & 2658,22 & 102.062 & 1220,57 & 712.611 \\
\hline 1993 & 675.756 & 51.63 & 3475,97 & 149.602 & 1137,08 & 773.719 \\
\hline 1994 & @97.577 & 39.758 & 4079,70 & 157.234 & 1404,46 & 815.053 \\
\hline
\end{tabular}

a hr.d. : não disponiveis

Fonte: Produção. exportação e importação. em toneladas : Anuário Estatistico do Brasil - diversos numeros (exceto dados de Produção referentes aos anos de 1990 a 1994 : dados publicados pelo IBGE. ratirados de Outlook (1997); exportação e importaçào. em USS/toneladas : construidos a partir de dados em dólares correntes extraidos de Giulietti \& Assumpção (1995), deflacionados pelo IPA-EUA (1990=100), indice asse extraido de IMF(1997): consumo aparente : construido a partir da förmula produção (Y) mais Importação (M) menos E.portação (X), para os anos de 1960 a 1994. Ressalta-se que para os quatro primeiros anos dessa variàvel (consumo aparente). nào foi adicionada a respectiva quantidade anual importada, uma vez que não foram encontrados dados de importações para os anos de 1960 a 1964. 
O impulso observado na produção do pescado de 1968 até 1974 está relacionado com a concessão de incentivos fiscais à pesca, através da promulgação do Decreto-lei $\mathrm{n}^{\mathbf{0}}$ 221, de 21/02/67. No período de 1967 a 1974 foram concedidos R\$ 793,49 milhões (em reais de agosto de 1994) como incentivos fiscais à pesca, com volume médio anual de $\mathrm{R} \$ 99,19$ milhões. Segundo Neiva (1990), essa política de incentivos possibilitou o surgimento de um parque industrial de qualidade para o pescado, permitindo a ocupação de áreas novas de pesca por frota nacional e contribuindo para o aumento da produção.

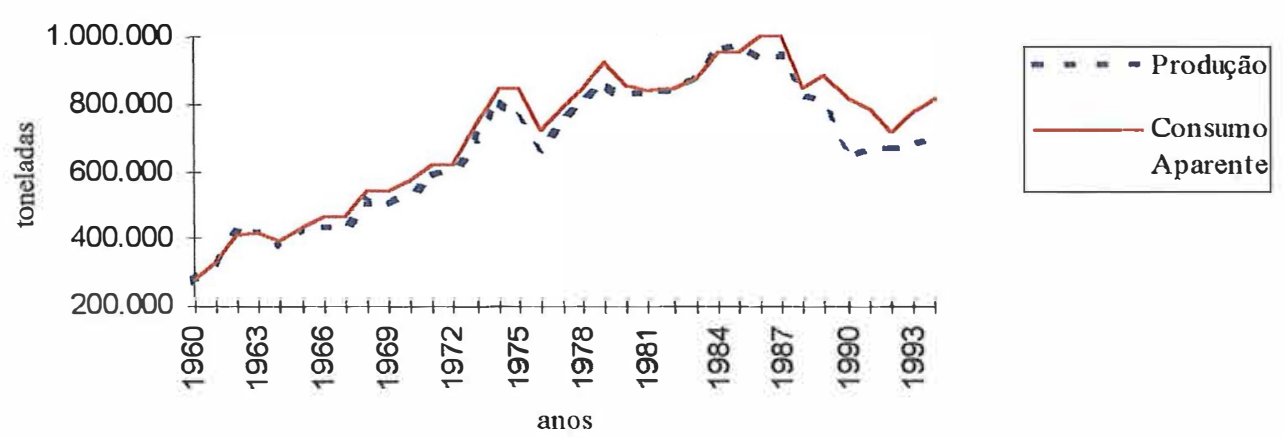

Figura 7 -Produção e Consumo A parente de Pescado no Brasil Fonte: Gráfico construído com dados da Tabela 2.

No período de 1975 a 1982 os incentivos fiscais concedidos à pesca foram de um valor anual médio de $\mathrm{R} \$ 23,82$ milhões (em reais de agosto de 1994). Esses recursos foram insuficientes para manter o crescimento da produção pesqueira nacional. Segundo relatório do IPEA/COMIF (1986), nesse período a SUDEPE priorizou o saneamento financeiro das empresas que se beneficiaram com recursos dos incentivos fiscais.

Nos anos de 1983 a 1985, as restrições às importações (inclusive de pescado) levaram a grande salto na produção nacional de pescado (ver Tabela 2) como modo de atender a demanda interna. Não obstante, a sobrepesca levou à redução dos estoques, contribuindo para a redução da produção a partir de 1986. 
O problema da sobrepesca foi ressaltado por muitos autores que estudam o recurso pesqueiro no País (por exemplo: Paez, 1993; Giulietti \& Assumpção, 1995; Tremel, 1993 e Neiva, 1990). Para esses autores, o Governo não considerou as potencialidades pesqueiras ${ }^{23}$ do litoral brasileiro ao lançar a política de incentivos fiscais à pesca, através do Decreto-lei 221/67.

A implementação da política de incentivos fiscais à atividade pesqueira superdimensionou a frota especializada na captura de determinadas espécies (esgotando, com o tempo, certos recursos pesqueiros) e superdimensionou a infra-estrutura de terra com instalação de plantas industriais com capacidade de produção superior ao abastecimento de matérias-primas (Giulietti \& Assumpção, 1995).

Conforme Tremel (1993), as águas que banham o litoral brasileiro são pobres em nutrientes, caracterizando uma limitada potencialidade dos recursos pesqueiros. Segundo o autor, no litoral brasileiro existe um enorme número de espécies de peixes, porém, poucas são capazes de formar estoques passiveis de serem explorados economicamente. Ressalta, ainda, que as correntes maritimas ${ }^{24}$ que passam pela costa brasileira são de temperaturas e salinidades elevadas, gerando baixa produtividade primária.

Além da produção pesqueira oriunda do mar, o Brasil possui grande volume de rios piscosos. Ver-se-á, no próximo item, como tem evoluído a produção pesqueira nacional de água doce e salgada e os impactos diferenciados que ocorrem sobre elas das políticas pesqueiras federais.

\subsubsection{Produção pesqueira marítima versus produção de água doce}

O Brasil dispõe de uma importante superficie de águas continentais, situadas, por exemplo, em rios, mangues de florestas e reservatórios aquáticos. Segundo

\footnotetext{
${ }^{23}$ Para Neiva (1990), a potencialidade dos recursos pesqueiros marinhos - a qualidade e o volume desses recursos são determinados, em grande parte, pelas caracteristicas fĩsicas, oceanográficas e climáticas das diferentes regiões da costa litorânea.

${ }^{24}$ As correntes maritimas deterninam, em grande parte, as condições ambientais dos recursos pesqueiros.
} 
Neiva (1990), muito pouco se conhece sobre a potencialidade produtiva dos recursos pesqueiros nessas águas.

A política federal voltada para a atividade pesqueira, ao longo das décadas de 60, 70 e 80, não gerou significativo efeito sobre a pesca de origem de água doce. No que se refere às regulamentações visando o ordenamento pesqueiro (de proteção ao recurso, explorando-o de forma racional), quase a totalidade delas voltam suas atenções à pesca marítima.

Quanto à política de conceder incentivos à atividade pesqueira, o Decretolei $n^{0} 221 / 67$ deixa claro em seu artigo $4^{\underline{0}}$ que esses incentivos se estendem também às águas interiores do Brasil. No entanto, avaliando os efeitos dessa política, observa-se, através do relatório IPEA/COMIF (1986), que os recursos foram canalizados basicamente para projetos de desenvolvimento enfatizando a matéria-prima de origem marítima.

No período de 1960 a 1994, a produção pesqueira nacional oriunda do mar representou $78 \%$ da produção média do pescado nacional, enquanto a produção nacional oriunda da pesca de água doce representou o equivalente a $22 \%$ da produção média brasileira (Tabela 3 )

A explicação para a predominância da pesca de origem marítima no total produzido de pescado está relacionada ao processo histórico de desenvolvimento da atividade pesqueira no Brasil. Conforme Diegues (1995), até o início do século XX as atividades pesqueiras eram realizadas por comunidades locais e nas águas próximas do litoral brasileiro. A partir de então, e ao redor dos centros urbanos, começou a se desenvolver a pequena pesca voltada para a venda no mercado. Nesse contexto surgiu a figura do atravessador, especializado em produtos do mar, que passou a ser, também, um financiador da produção dos pescadores artesanais. Após a Segunda Guerra Mundial, essa pequena pesca costeira (fazendo parte da cultura dos povos litorâneos) sofreu alterações significativas (como introdução das redes de náilon, do gelo, do motor de popa, de insumos não mais fabricados pelos pescadores - o que antes era usado), proporcionando maior estruturação à pesca de origem marítima em detrimento da pesca 
em água doce. Conforme analisado no item 3.1 do capítulo 3 deste estudo, a política pesqueira nacional nessa época estava mais direcionada para organizar a atividade pesqueira, não dando ênfase às regulamentações que preservassem o recurso pesqueiro de sua extinção.

Tabela 3: Participação da produção de pescado oriunda da pesca em água doce e marítima, no Brasil -1960 a 1994.

\begin{tabular}{|c|c|c|}
\hline Ano & $\begin{array}{c}\text { Pesca em água doce } \\
\%\end{array}$ & $\begin{array}{c}\text { Pesca marítima } \\
\%\end{array}$ \\
\hline 1960 & 19,5 & 78,4 \\
\hline 1961 & 18,3 & 79,8 \\
\hline 1962 & 16,1 & 81,5 \\
\hline $19 \Im 3$ & 18,7 & 80,6 \\
\hline 1964 & 25,1 & 74,8 \\
\hline 1965 & 22,4 & 77,4 \\
\hline 1966 & 19,3 & 80,6 \\
\hline 1967 & 20,6 & 79,3 \\
\hline 1968 & 21,4 & 78,2 \\
\hline 1969 & 22,4 & 77,3 \\
\hline 1970 & 19,7 & 80,2 \\
\hline 1971 & 16,5 & 83,4 \\
\hline 1972 & 13,7 & 86,3 \\
\hline 1973 & 12,6 & 87,4 \\
\hline 1974 & 15,4 & 84,6 \\
\hline 1975 & 22,9 & 77,1 \\
\hline 1976 & 22,0 & 78,0 \\
\hline 1977 & 22,4 & 77,6 \\
\hline 1978 & 19,9 & 80,1 \\
\hline 1979 & 14,8 & 85,2 \\
\hline 1980 & 22,7 & 77,3 \\
\hline 1981 & 23,7 & 76,3 \\
\hline 1982 & 24,8 & 75,2 \\
\hline 1983 & 23,3 & 76,7 \\
\hline 1984 & 22,1 & 77,9 \\
\hline 1985 & 21,7 & 78,3 \\
\hline 1986 & 22,0 & 78,0 \\
\hline 1987 & 24,6 & 75,4 \\
\hline 1988 & 24,7 & 75,3 \\
\hline 1989 & 27,5 & 72,5 \\
\hline 1990 & 32,3 & 67,7 \\
\hline 1991 & 30,4 & 69,6 \\
\hline 1992 & 30,1 & 69,9 \\
\hline 1993 & 30,2 & 69,8 \\
\hline 1994 & 29,2 & 70,8 \\
\hline
\end{tabular}

Fonte: De 1960 a 1989: Anuário Estatístico do Brasil - diversos números; de 1990 a 1994: dados publicados pelo IBAMA, IBGE e Instituto de Pesca/SP, retirados de Outlook (1997);

Nota: Os dados referentes aos anos de 1960 a 1971 não somam 100\% devido a imperfeições de não especificações do pescado capturado para esses anos, confonne indicado em Anuário Estatístico do Brasil - diversos números. 
Apesar da participação da produção de pescado de origem marítima ter se mostrado bem superior à participação da produção de pescado de origem de água doce, observam-se oscilações temporárias nas participações dessas duas fontes de pescado. No período de 1970 a 1974 e nos anos de 1978 e 1979, a produção de pescado oriunda da pesca marítima chegou a participar com, respectivamente, $80,2 \%, 83,4 \%, 86,3 \%, 87,4 \%$, $84,6 \%, 80,1 \%$ e $85,2 \%$ do total do pescado produzido no Brasil, reduzindo sua participação nos anos de 1990 a 1993 para, respectivamente; 67,7\%, 69,6\%, 69,9\% e $69,8 \%$ do total do pescado produzido pelo País. Considerando os anos de 1972 a 1974 e o ano de 1979, pode-se observar que a produção de pescado oriundo de água doce participou, respectivamente, com apenas $13,7 \%, 12,6 \%, 15,4 \%$ e $14,8 \%$ da produção total do pescado brasileiro, aumentando essa participação nos anos de 1990 a 1993 para cerca de $30 \%$ ao ano.

A razão para a oscilação dessas participações fundamenta-se, mais uma vez, na sobreexploração do recurso pesqueiro marítimo.

Da exposição realizada no item 3.1 desse capítulo, constata-se que, tanto a política federal orientada para regulamentar a exploração racional do recurso pesqueiro como a política federal que concedeu incentivos fiscais ao desenvolvimento da pesca no país são grandemente responsáveis pela sobreexploração do recurso pesqueiro. $\mathrm{Na}$ analise da politica de regulamentação (sub-item 3.1.1 desse capítulo), a preocupação com a exploração sustentavel do recurso somente se manifesta, com maior ênfase, no último período de regulamentações analisado (quarto periodo, de março de 1989 até os dias atuais), uma vez já constatada a sobrepesca de determinadas espécies. A análise da política de incentivos fiscais à pesca (sub-item 3.1.2 desse capítulo) indica que a aplicação dos recursos captados pelo Setor Agroindustrial do Pescado concentrou esforços no sentido de aumentar a produção pesqueira, porém, sem qualquer planejamento que permitisse a exploração racional do pescado (conforme avaliação do IPEA/COMIF, 1986). Ressalta-se ainda, segundo essa mesma fonte, a ineficiência do 
sistema de fiscalização existente, não contribuindo para "fazer valer" (ou enforcement) as regulamentações existentes na época.

Ao estudar a exploração dos recursos pesqueiros, Paez (1993) evidencia a situação de sobrepesca para grande parte das espécies de pescado capturadas comercialmente no litoral brasileiro. Segundo a autora, à exceção da Região Norte, nas demais regiões do país as espécies tradicionalmente capturadas, como lagosta, camarão, corvina, sardinha, pescada, merluza e tainha, entre outras, têm sido exploradas em níveis próximos do máximo rendimento sustentável, em alguns casos ocorrendo sobrepesca.

Como exemplo típico de sobrepesca, Paez (1993) cita o caso da sardinha, mostrando que o total de desembarque na Região Sudeste passa de 38.772 toneladas em 1964 para 113.877 toneladas em 1969, chegando a atingir o máximo de desembarque em 1973 (de 228 mil toneladas), para a partir de então ir declinando, chegando em 1990 a atingir 32 mil toneladas, uma quantidade de desembarque menor que a apresentada em 1964. Conforme Paez (1993, p.58):

"Caracteriza-se, nesse caso, uma situação de sobrepesca e de ociosidade, tanto em nível de frota como da indústria, acentuando-se a dependência das importações de sardinha para manter o setor em atividade e abastecer o mercado interno".

Outro exemplo de sobrepesca é o caso da produção de lagosta no Brasil. De acordo com DEFESA da lagosta ... (1998), somente no Estado do Ceará, onde está concentrado o principal setor lagosteiro do País, em 1997 a produção sofreu uma queda de 7,5\%. De 1991 a 1997, a queda acumulada chega a 46\%. Para o Brasil, a estimativa de captura sustentável anual é de cerca de 8.900 toneladas de lagosta inteira, correspondente a cerca de 3.000 toneladas de cauda (produto exportado). Até 1993/1994, a produção de lagosta mostrou tendência decrescente, estabilizando-se em torno de 8.000 toneladas nesses anos. Entretanto, no ano de 1995, a exploração atingiu 10.838 toneladas, constatando uma captura acima do nível sustentável desse recurso. Segundo essa mesma fonte, esse aumento na produção está relacionado a uma 
exploração não racional do recurso, mesmo existindo as legislações quanto à proibição de pesca em período de defeso e a limitação do tamanho para captura.

É interessante notar que, conforme BRASIL (1996), a potencialidade pesqueira na região do Oceano Atlântico sudoeste (região com condições oceanográficas similares às condições oceanográficas do litoral brasileiro) foi estimada em torno de 825 a 900 mil toneladas.

Ao comparar os dados de produção potencial (no parágrafo acima) com os dados da produção efetiva do pescado brasileiro (na Tabela 2) observam-se limites para expandir a produção pesqueira através da pesca extrativa marítima. Esses limites esbarram no uso racional do recurso pesqueiro, na diversificação e racionalização da atividade pesqueira (o que exige investimentos em pesquisa, fiscalização e controle).

Retornando aos dados da produção efetiva do pescado no Brasil (Tabela 2 e Figura 7), observa-se, apesar das oscilações, uma tendência de crescimento de 1960 a 1985, começando a declinar a partir de 1986. Nos anos 90, a produção pesqueira tem se situado em níveis pouco acima do observado em 1976 (658.847 toneladas). Ressalta-se, no entanto, que isso só tem sido possível pelo aumento da participação de pescado de águas interiores, justificado pela atenção da política federal para a pesca nacional estar, nos últimos anos, voltada para a aqüicultura (como visto no item 3.1.1).

Conforme WORKSHOP para subsidiar... (1996), atualmente a aqüicultura responde por uma oferta em torno de 40 mil toneladas por ano. Segundo Outlook (1997), projeta-se (com base num trabalho sério para o desenvolvimento desta atividade) a possibilidade de, num prazo de 10 anos, alcançar a produção de um milhão de toneladas na aqüicultura.

Segundo WORKSHOP para subsidiar... (1996), o Brasil é o país que apresenta o maior potencial do mundo para a produção de pescado através da aqüicultura. Tal afirmação baseia-se no vasto território brasileiro banhado por densa rede fluvial onde se destacam a bacia amazònica, os mais de 5 milhões de hectares de águas represadas em açudes (no Nordeste), os reservatórios construídos para a geração de energia hidroelétrica ou para abastecimento urbano, e também a imensidão de seus mais 
de 8 mil quilômetros de costa com muitas áreas que apresentam grande potencial para a maricultura.

Muitas áreas de atuação de pesquisas em aqüicultura estão sendo desenvolvidas no Brasil. Estas são destacadas no próximo item, caracterizando-as em nível regional.

\subsubsection{Análise da produção regional do pescado brasileiro}

A participação das cinco regiões do Brasil na produção de pescado brasileiro (no período de 1972 a 1989) é bastante desigual (Tabela 4). As Regiões Sudeste, Sul, Nordeste, Norte e Centro-Oeste apresentaram, respectivamente, participação média de $33,1 \%, 29,3 \%, 21,8 \%, 15,5 \%$ e $0,7 \%$ na produção total nacional.

Tabela 4: Participação percentual das regiões na produção pesqueira do Brasil, 1972 a 1989.

\begin{tabular}{cccccc}
\hline Ano & $\begin{array}{c}\text { Norte } \\
\%\end{array}$ & $\begin{array}{c}\text { Nordeste } \\
\%\end{array}$ & $\begin{array}{c}\text { Sudeste } \\
\%\end{array}$ & $\begin{array}{c}\text { Sul } \\
\%\end{array}$ & $\begin{array}{c}\text { Centro Oeste } \\
\%\end{array}$ \\
\hline 1972 & 9,1 & 23,0 & 34,3 & 33,4 & 0,2 \\
1973 & 8,6 & 21,3 & 31,9 & 38,1 & 0,1 \\
1974 & 10,4 & 20,4 & 34,6 & 34,5 & 0,2 \\
1975 & 16,9 & 21,6 & 30,3 & 30,9 & 0,3 \\
1976 & 16,0 & 21,4 & 30,0 & 32,3 & 0,3 \\
1977 & 16,9 & 21,2 & 29,5 & 31,9 & 0,5 \\
1978 & 13,8 & 24,3 & 31,5 & 29,8 & 0,6 \\
1979 & 10,6 & 19,1 & 32,7 & 37,0 & 0,6 \\
1980 & 17,4 & 22,6 & 31,8 & 27,4 & 1,1 \\
1981 & 18,5 & 23,6 & 35,0 & 21,8 & 1,0 \\
1982 & 18,1 & 24,7 & 31,6 & 24,5 & 1,2 \\
1983 & 17,6 & 22,0 & 33,6 & 25,5 & 0,9 \\
1984 & 16,2 & 20,7 & 35,6 & 26,7 & 1,1 \\
1985 & 15,4 & 21,0 & 34,9 & 27,6 & 0,2 \\
1986 & 15,5 & 21,8 & 35,5 & 25,9 & 0,6 \\
1987 & 18,6 & 21,3 & 37,8 & 22,0 & 0,7 \\
1988 & 18,8 & 21,6 & 33,6 & 25,3 & 3,1 \\
1989 & 21,5 & 21,4 & 30,8 & & \\
\hline
\end{tabular}

Fonte: Anuário Estatístico do Brasil, diversos números.

A distribuição regional da produção pesqueira é explicada por vários elementos, tais como: fatores ambientais (característica física, oceanográfica e climática da região), extensão do litoral, disponibilidade de rios, densidade demográfica e hábitos alimentares, entre outros. 
As Regiões Sudeste e Sul lideram a produção pesqueira com a maior participação na produção total do pescado brasileiro. Segundo informações publicadas em BRASIL (1996), essas regiões apresentam produção primária elevada, causada por correntes marítimas vindas das Malvinas (região litorânea do Sul da América do Sul). Além disso, possuem maior densidade demográfica e maior renda, gerando um grande mercado consumidor.

O Nordeste é a terceira região que mais participa na produção pesqueira do país. Apesar de sua grande extensão costeira, essa região é caracterizada pela baixa produção primária. Segundo Neiva (1990), isto é explicado pela predominância de águas quentes e salinas no litoral nordestino.

A Região Centro-Oeste possui maior densidade demográfica que a Região Norte. Contudo, esta última tem mais rios e maior tradição no consumo de peixes. Daí haver maior produção de pescado no Norte do que no Centro-Oeste.

A produção primária da Região Norte é relativamente alta, sendo beneficiada pela grande influência do Rio Amazonas, que, através do fornecimento de nutrientes, favorece a abundância de pescado.

Quando se analisa o preço unitário do pescado brasileiro, por região, encontram-se algumas diferenças importantes (Tabela 5).

Tabela 5: Preço por unidade da produção de pescado, por região, Brasil, 1980-1989 - em US\$/tonelada.

\begin{tabular}{|c|c|c|c|c|c|}
\hline & Norte & Nordeste & Sudeste & Sul & Centro Oeste \\
\hline & US\$Ron & US\$Ron & US\$ROn & US\$Aton & US\$rton \\
\hline 1980 & 816,99 & 1508,15 & 518,71 & 512,72 & 1330,04 \\
\hline 1981 & 702,25 & 1346,62 & 453,70 & 491,46 & 735,73 \\
\hline 1982 & 783,45 & 1306,61 & 557,43 & 601,21 & 589,24 \\
\hline 1983 & 662,50 & 978,97 & 397,32 & 373,47 & 590,10 \\
\hline 1984 & 652,94 & 1026,67 & 399,85 & 390,36 & 667,28 \\
\hline 1985 & 98,45 & 958,15 & 409,98 & 389,04 & 542,45 \\
\hline 1986 & 842,98 & 1362,64 & 591,55 & 573,20 & 898,42 \\
\hline 1987 & 790,86 & 1502,00 & 585,10 & 500,55 & 1068,90 \\
\hline 1988 & 787,95 & 1536,94 & 682,04 & 528,98 & 930,66 \\
\hline 1989 & 2096,37 & 2810,29 & 1042,43 & 519,03 & 2328,56 \\
\hline
\end{tabular}

Fonte: Preços em US\$/tonelada, construídos a partir de dados de produção extraídos de Anuário Estatístico do Brasil - diversos números, e de dados em dólares correntes extraídos de Giulietti \& Assumpção (1995), detlacionados pelo IPA-EUA (1990=100), índice esse extraído de $\operatorname{IMF}(1997)$. 
$\mathrm{Na}$ Região Nordeste registra-se o maior preço médio por unidade (um valor médio, na década de 80 , de US\$1.433,70 por tonelada), enquanto as Regiões Sudeste e Sul apresentaram os menores preços médios anuais por unidade, respectivamente, US\$563,81 e US\$488 por tonelada. Conforme Giulietti \& Assumpção (1995), a Região Nordeste produz muitos produtos finos (lagosta, camarão etc.), de elevado valor unitário, sendo quase toda a produção destinada à exportação.

As Regiões Sudeste e Sul produzem maior quantidade de pescado, porém, de características mais comuns e de baixo valor unitário. São espécies de peixes de grandes cardumes, como sardinha, cavalinha, pescada, corvina, anchova, goete; e de crustáceos, como o camarão de sete barbas.

A despeito das características inerentes a cada região, classificando-as como importantes para o país com base na quantidade produzida bem como no preço e tipo de produto específico por região, ressalta-se nesse contexto, de tamanha importância, a distribuição regional dos incentivos fiscais destinados a desenvolver a pesca no país.

De acordo com IPEA/COMIF (1986), até junho de 1985 os recursos captados via incentivos fiscais destinados a empreendimentos pesqueiros estavam distribuídos, regionalmente, da seguinte forma: para a Região Norte $5,71 \%$, para a Região Nordeste $15,27 \%$, para a Região Sudeste 53,01\%, para a Região Sul 24,51\%, e para a Região Centro-Oeste apenas 1,50\% dos recursos. Observa-se, desses dados, que as regiões que mais produzem o pescado no Brasil são também as que mais receberam incentivos fiscais para desenvolver esse setor (Sudeste, Sul e Nordeste).

Conforme mencionado no item anterior, nos últimos anos o pescado cultivado tem aumentado sua participação no total da produção do pescado brasileiro. A nível regional, algumas características da aqüicultura são levantadas.

Na Tabela 6 são apresentados dados regionais do pessoal qualificado envolvido na atividade aqüícola no Brasil. 
Tabela 6 - Recursos humanos envolvidos na aqüicultura. por região. 1995.

\begin{tabular}{l|c|c|c|c}
\hline \multirow{2}{*}{ Região } & \multicolumn{3}{c|}{ Nivel de qualificação } & \multirow{2}{*}{ Total } \\
\cline { 2 - 4 } & Graduados & Mestres & Doutores & 41 \\
Norte & 09 & 27 & 05 & 145 \\
Nordeste & 84 & 32 & 29 & 13 \\
Centro-Oeste & 04 & 08 & 01 & 248 \\
Sudeste & 112 & 61 & 75 & 110 \\
Sul & 55 & 31 & 24 & 557 \\
\hline Total & 264 & 159 & 134 & \\
\hline
\end{tabular}

Fonte: Dados montados a partir de informações em WORKSHOP para subsidiar ... (1996).

Pela Tabela 6 observa-se que grande parte do pessoal qualificado, ocupado na atividade de cultivo do pescado, está concentrada nas Regiões Sudeste, Nordeste e Sul. Esse pessoal qualificado está vinculado a instituições de pesquisa, extensão, fomento e consultoria, distribuídas ao longo dos Estados respectivos a cada região.

De acordo com Araújo et al. (1996), no Brasil existem apenas três cursos de graduação em Engenharia de Pesca, sendo que dois desses cursos estão na Região Nordeste (na Universidade Federal do Ceará -UFC, e na Universidade Federal Rural de Pernambuco - UFRPe), e o terceiro na Região Norte (na Universidade do Amazonas). Assim, pode-se sugerir que boa parte do pessoal contabilizado na Tabela 6 trata-se de outros tipos de diplomados que se especializaram na aqüicultura.

A Região Norte conta, em todos os seus Estados, com diversas Instituições que se dedicam à extensão e fomento da aqüicultura. Porém, o atendimento é muito precário devido à falta de especialização na área, apesar dessa região ter um grande potencial para a aqüicultura. As atividades de formação e de pesquisa estão concentradas nos Estados do Amazonas e no Pará (WORKSHOP para subsidiar ..., 1996). Quando considera-se o número de aqüicultores, essa região é a terceira do país, entretanto, apresentando quantidade produzida de pescado mais baixa em todo o pais, cerca de 2.079,5 toneladas/ano (Tabela 7). Nessa região, os aqüicultores são, na maioria, de pequeno porte. Somente no Acre, onde estão cadastrados 2.000 aqüicultores, esses utilizam uma área média de 0,5 hectares, com produtividade de 1 ton./ha. 
Tabela 7 - Número de aqüiicultores e produção da aqüicultura para consumo. por região. 1995.

\begin{tabular}{l|c|c}
\hline Região & $\begin{array}{c}\text { Aqüicultores } \\
\text { (número) }\end{array}$ & $\begin{array}{c}\text { Produção } \\
\text { (Ton./Ano) }\end{array}$ \\
\hline Norte & 3.582 & $2.079,5$ \\
Nordeste & 1.132 & $3.982,17$ \\
Centro-Oeste & 726 & 6.056 \\
Sudeste & 2.443 & $10.897,9$ \\
Sul & $>29.000$ & $>19000$ \\
\hline
\end{tabular}

Fonte: Dados montados a partir de informações em WORKSHOP para subsidiar ... (1996).

Nota: Segundo a fonte, os dados apresentados representam uma estimativa, tendo em vista a grande dificuldade no seu levantamento.

A Região Nordeste dispõe de recursos hidricos abundantes, como alguns rios de porte consideráveis como o São Francisco e o Paranaíba, com grandes barragens para geração de energia elétrica e inúmeros açudes construídos para combater o fenômeno das secas. Essa região apresenta condições climáticas excepcionais, com temperaturas elevadas e uniformes durante todo o ano, tornando possível o cultivo de qualquer espécie de origem tropical, com altos índices de produtividade (WORKSHOP para subsidiar ..., 1996).

Nessa região, a atividade de aqüicultura é exercida, principalmente, através de dois segmentos: a piscicultura de água doce e a carcinicultura (cultivo de camarão). A piscicultura de água doce produz pescado como tilápias, pescada, tucunaré e tambaqui. A carcinicultura marinha é praticada há algum tempo, enquanto o cultivo de camarões na água doce é recente. Os primeiros empreendimentos comerciais de cultivo de camarão marinho surgiram na década de 70 . Geralmente, os grandes projetos estão concentrados no cultivo do camarão marinho, não tendo problemas de comercialização, possuindo uma infra-estrutura de processamento do pescado, o que facilita a colocação do produto no mercado. Já os pequenos produtores, que não detêm a tecnologia de processamento, usam recursos simples como a salga, ou a comercialização do produto fresco em feiras populares.

A Região Nordeste é a segunda do país que apresenta o maior nível de qualificação do pessoal ocupado nas instituições voltadas para o desenvolvimento da atividade aqüícola (ver Tabela 6). Segundo dados de WORKSHOP para subsidiar ... (1996), o número de pesquisadores com qualificação adequada nos Estados nordestinos é 
considerado razoável, e, aproximadamente $80 \%$ desse contingente de pesquisadores está ligado às Universidades públicas. Ressalta-se ainda que, além do curso de graduação em Engenharia de Pesca, a UFC oferece, em nível de pós-graduação, cursos de especialização em aqüicultura e Mestrado em Engenharia de Pesca e a UFRPe oferece também cursos de especialização em aqüicultura.

Apesar de apresentar um quadro favorável do nível de qualificação do pessoal ocupado na aqüicultura, a Região Nordeste apresenta um número relativamente pequeno de aqüicultores cadastrados (cerca de 1.132), e uma produção de 3.982,17 ton./ano, ficando à frente em quantidade produzida apenas da Região Norte, que possui pequena infra-estrutura nessa atividade (ver Tabela 7). Conforme WORKSHOP para subsidiar ... (1996), os órgãos de extensão nordestinos se encontram em condições precárias, além de serem voltados mais para o setor agrícola, dificultando qualquer ação para o desenvolvimento da aqüicultura. Existem laboratórios bem estruturados, porém subutilizados, e muitos necessitando de recuperação e/ou modernização de suas instalações. Grande parte das pesquisas conta com a própria infra-estrutura existente nas universidades.

Conforme os dados da Tabela 6, a Região Centro-Oeste é a que menos possui pessoal qualificado em cultivo do pescado no Brasil, apresentando um número bastante pequeno quando comparado às demais regiões. Em termos de quantidade de aqüicultores, essa região também apresenta um número reduzido (726), porém, é a terceira região do Brasil que mais produz, atingindo cerca de 6.056 ton./ano, perdendo em produção para as Regiões Sul e Sudeste (ver Tabela 7). A produção aqüícola da Região Centro-Oeste é representada basicamente por cultivos de peixes (como pacu e tambaqui, espécies da região).

Numa avaliação realizada por WORKSHOP para subsidiar ... (1996), constata-se que o grande problema da Região Centro-Oeste é a falta de um serviço de extensão que proporcione transferência de tecnologia de criação de espécies nativas mais adequadas às características típicas dessa região (de temperatura elevada durante o ano todo), de forma a obter elevadas produtividade. Nesta região estão sendo direcionados 
grandes investimentos para a criação do pacu, principalmente nos Estados de Mato Grosso e Mato Grosso do Sul, onde já existem alguns municípios com piscicultores de grande porte.

A Região Sudeste ocupa o segundo lugar como maior produtora de pescado cultivado atingindo, no ano de 1995 , cerca de $25 \%$ do total produzido no ano (ver Tabela 7). Destaca-se nesta região a produção de peixes de água doce, com tendência de ampliação dessa produção por empresas que exploram a pesca esportiva (os “pesque-pague”). Grande parte da produção de peixes na Região Sudeste se concentra no Estado de São Paulo. No Estado de Minas Gerais existe a produção de trutas, de forma bem organizada e que apresenta perspectivas de maior crescimento [ver WORKSHOP para subsidiar ... (1996)].

A Região Sudeste apresenta aspectos favoráveis ao desenvolvimento da aqüicultura. Do total do pessoal qualificado ocupado nas atividades de pesquisa, extensão e fomento da aqüicultura brasileira, cerca de $45 \%$ pertence a essa região (Tabela 6). Segundo WORKSHOP para subsidiar ... (1996), são várias as razões que caracterizam a Região Sudeste como favorável a essa atividade: a capacitação tecnológica (que aglomera nas Universidades e Institutos de Pesquisa grande parte dos pesquisadores que atuam nesta área); boa infra-estrutura para realizar pesquisas e oferecer cursos de treinamento; grande potencial para a produção do pescado (reservatórios construídos para gerar energia hidroelétrica, etc.); grande concentração industrial e populacional, com razoável poder aquisitivo (caracterizando essa região com grande potencial para o consumo do pescado).

A Região Sul lidera a produção aqüícola nacional, apresentando uma produção superior a 19.000 toneladas, em 1995, elaborada por mais de 29.000 aqüicultores (ver Tabela 7). Segundo WORKSHOP para subsidiar ... (1996), essa quantidade de aqüicultores é conseqüência da estrutura fundiária da região, onde predominam pequenos proprietários. Paraná e Santa Catarina são os Estados que mais produzem pescado cultivados, atingindo um percentual superior a $90 \%$ do total produzido em toda a região. O Estado do Paraná conta com mais de 19 mil pequenos 
piscicultores, produzindo pescado de água doce, principalmente tilápias. O Estado de Santa Catarina registra uma produção ao redor de 8 mil toneladas (de peixes, moluscos e crustáceos).

Conforme WORKSHOP para subsidiar ... (1996), o potencial hídrico dessa região é muito rico, considerando tanto os grandes rios e nascentes existentes, como a orla marítima com correntes marinhas fracas ou moderadas e o grande número de baías e enseadas, propícias para a maricultura. A região também apresenta uma razoável disponibilidade de recursos humanos dedicados às atividades de ensino e pesquisa (ver Tabela 6), com infra-estrutura disponível para essas atividades, formada por Estações de Aqüicultura e Laboratórios localizados nas Universidades, tais como: FURG (Laboratórios de Maricultura e Aqüicultura interior); UFSM (laboratório de águas interiores); UFRGS (laboratórios para pesquisa com espécies de água doce); UFSC (Estação de Aqüicultura de Itacorobi, Estação de Maricultura da Barra da Lagoa e Estação experimental de Camboriu/SC).

\subsubsection{O consumo aparente do pescado e as transações externas com este produto}

O consumo aparente de pescado pelo Brasil apresenta oscilações ao longo do período de 1964 a 1994 (ver Tabela 2 e Figura 7). Em 1964, o consumo aparente estava em torno de 397 mil toneladas, mantendo uma tendência crescente até 1974, quando atingiu 848 mil toneladas. De 1974 a 1983 esse consumo manteve-se ao redor das 800 mil toneladas por ano, ultrapassando 900 mil toneladas anuais no período de 1984 a 1987.

Observa-se que, durante todo o período apresentado na Tabela 2 (desconsiderando os anos de 1960 a 1963, onde não são registradas as quantidades importadas), o consumo aparente do pescado foi superior à produção pesqueira nacional, com exceção dos anos de 1983, 1984 e 1985. Isso ocorria devido a quantidade importada de pescado ser maior que a quantidade exportada. Para os anos que marcam a primeira metade da década de 80 , deve-se considerar que a economia brasileira passava por forte 
crise econômica, afetada por uma política cambial severa de maxidesvalorização da moeda nacional, o que pode ter contribuído para reduzir as importações do pescado brasileiro.

A oscilação da produção brasileira de pescado (examinada no item 3.2.1) e sua insuficiência em atender o consumo interno impactou o comércio externo desse produto.

A exportação brasileira de pescado aumentou de 10.134 toneladas em 1970, a um preço médio de US $\$ 5.808,29$ por tonelada, para 53.250 toneladas em 1985, a um preço médio de US $\$ 3.613,88$ por tonelada (ano em que a produção brasileira atingiu seu nível máximo, no período analisado). Do início da década de 80 ao início da década de 90 , as exportações situaram-se em torno de 40 mil toneladas anuais, atingindo o nível máximo exportado no ano de 1992 (55.237 toneladas ao preço médio de US $\$ 2.658,22$ por tonelada). Em 1993 e 1994, as quantidades exportadas de pescado pelo Brasil apresentaram tendência decrescente e seus respectivos preços foram crescentes, passando de US\$3.475,97 por tonelada em 1993 para US\$4.079,70 por tonelada em 1994. Segundo Outlook (1997), essa tendência decrescente da quantidade exportada, nos últimos anos, é atribuída a causas como a redução dos estoques pesqueiros. Exemplo disso é o caso da produção da lagosta, apresentado no item 3.2.2 desse capítulo.

As importações brasileiras de pescado situaram-se, durante o período de 1970 a 1985, em torno de 56 mil toneladas ao ano, com preço médio de US\$1.482,08 por tonelada. A partir de 1986 as importações brasileira de pescado cresceram significativamente, ultrapassando as 100 mil toneladas em 1987, e chegando a 214.190 toneladas no ano de 1990 , ao preço de US\$936,41 por tonelada (o nível máximo importado pelo Brasil, considerando a série analisada). A elevação da quantidade importada para a casa das 100 mil toneladas/ano, a partir de 1986, está relacionada aos efeitos da política pesqueira nacional, que levou à redução do estoque de matéria-prima (como analisado nos itens 3.1.1 e 3.1.2 desse capítulo). Com a tendência decrescente da produção pesqueira após 1986 (como mostrado no item 3.2.1 desse capítulo), houve a necessidade de aumentar as importações de pescado. 
Conforme Neiva (1990), grande parte do aumento das importações brasileiras de pescado foi para atender à demanda industrial. Como exemplo, o autor cita o caso da importação de sardinhas para atender à demanda do parque de enlatados do Rio de Janeiro, afetado pelas quedas na produção da sardinha nacional ${ }^{25}$. Observa-se, dessa forma, a não preocupação da política pesqueira nacional com a exploração racional do pescado brasileiro, culminando com a existência de uma capacidade produtiva industrial superdimensionada para essa espécie.

Comparando as exportações com as importações brasileiras de pescado, pode-se observar (Tabela 2 e Figura 8) que, em termos de quantidades físicas, as importações de pescado pelo Brasil se mantiveram, por quase todo o período analisado, bem acima das quantidades de pescado exportadas. O mesmo não ocorre quando se analisa em termos de preços por unidade. Pela Tabela 2, observa-se que os preços/tonelada do pescado exportado se mantiveram, em grande parte do período, em nível superior aos preços/tonelada do pescado importado pelo Brasil.

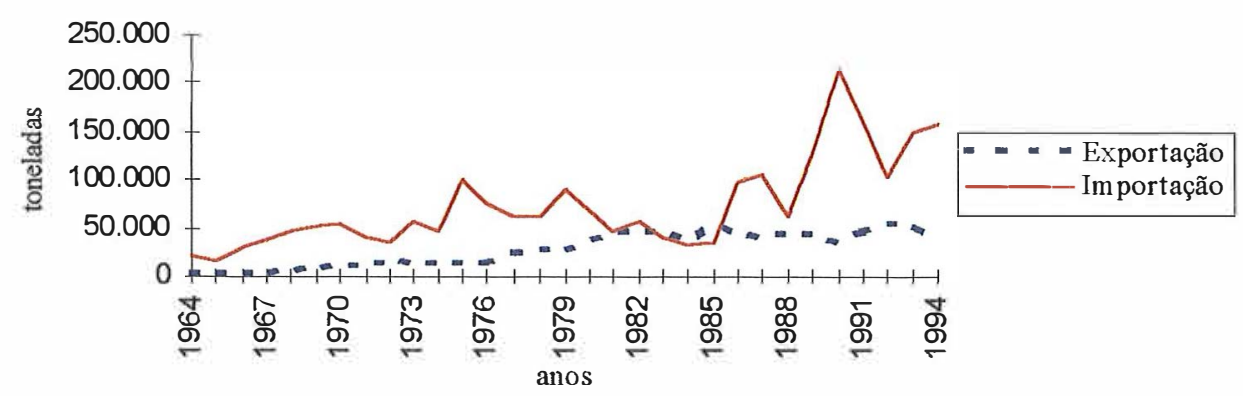

Figura 8 - Eyortação e Importação de Pescado no Brasil Fonte: Gráfico construído com dados da Tabela 2.

O Brasil exporta menor quantidade de pescado e com alto valor unitário e importa quantidade maior de pescado de menor preço unitário. Isto porque, segundo Neiva (1990), os produtos exportados pelo Brasil são espécies de pescado fino, de alto valor unitário (como lagostas, camarões, etc.) e, em sua maioria, são exportados para países desenvolvidos (em especial os E.U.A.). De outro lado, as importações de pescado

${ }^{25}$ Ver sobre a queda na produção de sardinha no item 3.2 .2 do capítulo 3 desse estudo. 
pelo Brasil são, na maior parte, de peixes das espécies mais comuns, para consumo no mercado interno (peixes secos, salgados ou em salmoura, bem como peixes frescos, resfriados e congelados, como sardinha, pescada, corvina, merluza, pescadinha, etc.). 


\section{ANÁlise BENEFÍCIO-CUSTO DOS PROGRAMAS FEDERAIS DE INCENTIVOS FISCAIS À PESCA}

Este capítulo apresenta, numa primeira etapa, os resultados das estimativas das equações de demanda e oferta de mercado do pescado no Brasil, utilizadas para quantificar os benefícios sociais gerados pelo programa de incentivos fiscais à pesca. Numa segunda e última etapa, apresentam-se os resultados do cálculo do beneficio social gerado pelos incentivos fiscais concedidos à atividade pesqueira no Brasil, usando a metodologia exposta no item 2.2 do capítulo 2, e o compara com o custo social desses incentivos.

\subsection{Estimativa das equações de demanda e da oferta de pescado no Brasil}

As estimativas das equações de demanda e de oferta de pescado [equações (6), (7) e (8) do item 2.2 do capítulo 2) foram realizadas através de um modelo de equações simultâneas, utilizando o método dos mínimos quadrados em dois estágios. As informações utilizadas são referentes aos anos de 1960 a 1994 (veja Tabela 8). 
Tabela 8: Dados usados para estimar equações de oferta e demanda de pescado no Brasil, 1960 a 1994

\begin{tabular}{|c|c|c|c|c|c|c|c|c|}
\hline ANOS & $R_{1}$ & $\mathrm{QD}_{\mathrm{t}}$ & $\mathrm{QS}_{\mathrm{t}}$ & $\mathrm{POP}_{\mathrm{t}}$ & $\mathrm{PB}_{\mathrm{t}}$ & $\mathrm{PF}_{\mathrm{t}}$ & $P_{t}$ & $I F_{t}$ \\
\hline 1960 & $1,10976 \mathrm{E}+11$ & 280.306 .000 & 281.512 .000 & 70.070 .457 & 2,14 & 2,93 & 0,99 & 0 \\
\hline 1961 & $1,18340 \mathrm{E}+11$ & 328.299 .000 & 330.140 .000 & 72.095 .493 & 2,27 & 2,58 & 0,92 & 0 \\
\hline 1962 & $1,24670 \mathrm{E}+11$ & 412.566 .000 & 414.640 .000 & 74.179 .053 & 2,25 & 2,67 & 0,93 & 0 \\
\hline 1963 & $1.28733 \mathrm{E}+11$ & 419.564 .000 & 421.365 .000 & 76.322 .828 & 2,09 & 2,53 & 0,90 & 0 \\
\hline 1964 & $1,32590 \mathrm{E}+11$ & 397.079 .000 & 398.898 .000 & 78.528 .557 & 1,83 & 2,10 & 0,83 & 0 \\
\hline 1965 & $1,36747 \mathrm{E}+11$ & 436.581 .000 & 439.019 .000 & 80.798 .033 & 1,83 & 2,46 & 0,86 & 0 \\
\hline 1966 & $1,45308 \mathrm{E}+11$ & 461.617 .000 & 464.585 .000 & 83.133 .096 & 2,52 & 2,25 & 0,85 & 0 \\
\hline 1967 & $1,48950 \mathrm{E}+11$ & 464.900 .000 & 468.269 .000 & 85.535 .642 & 2,02 & 2,08 & 0,89 & $16.072 .329,35$ \\
\hline 1968 & $1,66778 \mathrm{E}+11$ & 539.272 .000 & 545.356 .000 & 88.007 .622 & 1,80 & 2,07 & 0,87 & $61.810 .937,94$ \\
\hline 1969 & $1.82591 \mathrm{E}+11$ & 542.906 .000 & 552.267 .000 & 90.551 .043 & 1,70 & 1,64 & 1,01 & $180.679 .397,49$ \\
\hline 1970 & $1,96672 \mathrm{E}+11$ & 570.635 .000 & 580.769 .000 & 93.139 .037 & 1,96 & 1,97 & 0,95 & 213.618 .603 .87 \\
\hline 1971 & $2,17321 \mathrm{E}+11$ & 619.656 .000 & 631.048 .000 & 95.448 .885 & 2,36 & 1,84 & 1,21 & $138.422 .250,40$ \\
\hline 1972 & $2.48444 \mathrm{E}+11$ & 622.043 .000 & 639.465 .000 & 97.816 .017 & 2,57 & 2,01 & 1,32 & $78.188 .630,07$ \\
\hline 1973 & $3.19263 \mathrm{E}+11$ & 743.228 .000 & 755.780 .000 & 100.241 .855 & 3,30 & 2,37 & 1,55 & $64.325 .752,21$ \\
\hline 1974 & $3,61361 \mathrm{E}+11$ & 848.343 .000 & 862.075 .000 & 102.727 .853 & 3,44 & 2,11 & 1,27 & $40.372 .888,48$ \\
\hline 1975 & $3,97590 \mathrm{E}+11$ & 844.404 .000 & 859.261 .000 & 105.275 .503 & 2,88 & 1,96 & 1.08 & $43.561 .258,02$ \\
\hline 1976 & $4,39024 \mathrm{E}+11$ & 722.012 .000 & 735.780 .000 & 107.886 .336 & 2,53 & 1,82 & 1,32 & $34.325 .725,06$ \\
\hline 1977 & $4,69991 \mathrm{E}+11$ & 790.253 .000 & 814.458 .000 & 110.561 .917 & 2,47 & 1,70 & 1,10 & $29.675 .713,51$ \\
\hline 1978 & $4.91245 \mathrm{E}+11$ & 841.946 .000 & 868.364 .000 & 113.303 .853 & 3,24 & 1,79 & 1,07 & $24.616 .074,43$ \\
\hline 1979 & $5,25781 \mathrm{E}+11$ & 920.244 .000 & 947.741 .000 & 116.113 .788 & 4,39 & 1,91 & 1,56 & $23.495 .159,76$ \\
\hline 1980 & $5,45978 \mathrm{E}+11$ & 855.015 .000 & 889.477 .000 & 119.002 .706 & 3,79 & 1,56 & 1,42 & $13.866 .656,98$ \\
\hline 1981 & $5,00991 \mathrm{E}+11$ & 833.445 .000 & 878.555 .000 & 121.299 .458 & 2,69 & 1,40 & 1,18 & $11.855 .446,75$ \\
\hline 1982 & $5,17796 \mathrm{E}+11$ & 844.605 .000 & 890.448 .000 & 123.640 .538 & 2,30 & 1,19 & 1,30 & $9.201 .719,78$ \\
\hline 1983 & $4,57006 \mathrm{E}+11$ & 875.109 .000 & 922.475 .000 & 126.026 .800 & 2,85 & 1,40 & 1,19 & $10.929 .973,55$ \\
\hline 1984 & $4,50935 \mathrm{E}+11$ & 953.561 .000 & 990.547 .000 & 128.459 .117 & 3,09 & 1,45 & 1,22 & $8.178 .094,39$ \\
\hline 1985 & $5,23260 \mathrm{E}+11$ & 954.510 .000 & 1.007 .760 .000 & 130.938 .378 & 2,71 & 1,47 & 1,24 & $6.707 .685,64$ \\
\hline 1986 & $5,76253 \mathrm{E}+11$ & 996.978 .000 & 1.039 .529 .000 & 133.465 .489 & 3,13 & 1,64 & 1,54 & 5.921 .255 .53 \\
\hline 1987 & $5,64945 \mathrm{E}+11$ & 998.772 .000 & 1.039 .750 .000 & 136.041 .373 & 2,61 & 1,18 & 1,42 & \\
\hline 1988 & $5,23196 \mathrm{E}+11$ & 848.083 .000 & 891.654 .000 & 138.666 .971 & 2.35 & 1,22 & 1,33 & \\
\hline 1989 & $5,34897 \mathrm{E}+11$ & 880.710 .000 & 925.064 .000 & 141.343 .244 & 2,19 & 1,11 & 1,45 & \\
\hline 1990 & $4.85322 \mathrm{E}+11$ & 813.024 .000 & 847.789 .000 & 144.071 .169 & 1,88 & 0.91 & 1.47 & \\
\hline 1991 & $4,93324 \mathrm{E}+11$ & 783.138 .000 & 828.377 .000 & 146.825 .475 & 1,89 & 0.80 & 1,49 & \\
\hline 1992 & $4,87754 \mathrm{E}+11$ & 712.611 .000 & 767.848 .000 & 148.851 .667 & 1,84 & 0,82 & 1,51 & \\
\hline 1993 & $4,86477 \mathrm{E}+11$ & 773.719 .000 & 825.358 .000 & 150.905 .820 & 1,87 & 0,76 & 1,53 & \\
\hline 1994 & $5,14381 E+11$ & 815.053 .000 & 854.811 .000 & 152.988 .320 & 1,76 & 0,70 & 1,55 & \\
\hline
\end{tabular}

Fonte: $\mathrm{R}_{\mathrm{t}}$ (Produto Interno Bruto a preços de mercado), em $\mathrm{R} \$$ de agosto de 1994, calculado a partir dos dados do Anuário Estatistico do Brasil, diversos números; $\mathrm{QD}_{\mathrm{t}}$ (quantidade demandada de pescado no Brasil), expresso em Kg e QS ${ }_{t}$ (quantidade ofertada de pescado no Brasil), expresso em $\mathrm{Kg}$, ambas variáveis construidas a partir de dados de produção, exportação e importação do pescado brasileiro, retirados do Anuário Estatístico do Brasil, diversos números; POP $_{\mathrm{t}}$ (população residente no Brasil), em número de habitantes, retirados de Anuário Estatístico do Brasil, diversos números; $\mathrm{PB}_{\mathrm{t}}$ (preço da came de boi no Estado de São Paulo), expresso em $\mathrm{R} \$$ de agosto de 1994 por $\mathrm{Kg}$, calculados a partir de dados mensais de preço do boi gordo no Estado de São Paulo, dados extraídos dos Anuários Estatísticos do Instituto de Economia Agrícola - IEA/SP; PFt (preço da came de frango para corte no Estado de São Paulo), expresso em $\mathrm{R} \$$ de agosto de 1994 por $\mathrm{Kg}$, calculados a partir de dados mensais de preço do frango para corte no Estado de São Paulo, dados extraídos dos Anuários Estatísticos do Instituto de Economia Agrícola - EA/SP; $\mathrm{P}_{\mathrm{t}}$ (preço do pescado no Brasil), expresso em R\$ de agosto de 1994 , por $\mathrm{Kg}$, calculado a partir de dados de valor e produção do pescado publicados pelo Anuário Estatístico do Brasil, diversos números: $\mathbb{F}_{t}$ (incentivos fiscais concedidos à pesca brasileira), em $\mathrm{R} \$$ de agosto de 1994, retirados da Tabela tomecida pelo Banco do Nordeste do Brasil, com valores anuais, em cruzeiros correntes, referentes à distribuição dos incentivos fiscais aplicados a setores e regiões. Para transformar os valores fornecidos em cruzeiros correntes para reais utilizou-se o IGP-DI de agosto de 1994=100 
Várias regressões foram estimadas (ver Apêndice B), sendo selecionada a seguinte (onde $Q D_{t}, Q S_{t}$ e $R_{t}$ estão em valores per capita):

- Equação de demanda de pescado:

$$
\begin{aligned}
\mathrm{L} Q D_{t}= & -0,6682-0,4322 \cdot \mathrm{L} P_{t}+0,3705 \cdot \mathrm{L} P B_{t}+0,2874 \cdot \mathrm{L} R_{t} \\
& (-0,595)^{\mathrm{n} / \mathrm{s}}(-1,603)^{* *} \quad(4,072)^{*} \quad(1,938)^{*} \\
& R^{2}=0,8359 \quad F=50,9618^{*} \quad D W=2,2512^{\mathrm{s} / \mathrm{a}}
\end{aligned}
$$

- Equação de oferta de pescado:

$$
\begin{aligned}
& \mathrm{L} Q S_{t}= 1,6856+0,4243 \cdot \mathrm{L} P_{t}+0,0113 \cdot \mathrm{L} I F_{t-k} \\
&(29,1136)^{*}(2,4699)^{*} \quad(3,4418)^{*} \\
& R^{2}=0,6822 \quad F=33,2834^{*} D W=1,9207^{\mathrm{sa}}
\end{aligned}
$$

onde:

a) as variáveis são expressas em logaritmo neperiano (L); -0,6682 e 1,6856 são as constantes da equação de demanda e oferta, respectivamente; $P_{t}$ é o preço do pescado no ano $\mathrm{t} ; P B_{t}$ é o preço da carne de boi no ano $\mathrm{t} ; R_{t}$ representa a renda per capita no ano t. $I F_{t-k}$ é o volume de incentivos fiscais concedidos à atividade pesqueira no ano $\mathrm{t}-\mathrm{k}$ (onde $\mathrm{k}=0$ );

b) *: significativo a $1 \%$; **: significativo a $11 \%$; $\mathrm{n} / \mathrm{s}$ : não significativo; s/a: sem autocorrelação residual.

c) os números entre parênteses são as estatísticas t de student.

Os sinais dos coeficientes da equação de demanda do pescado estão de acordo com o esperado. Os coeficientes referentes às variáveis renda $\left(R_{t}\right)$ e preço do bem substituto $\left(P B_{t}\right)$ foram significativos a $1 \%$ de probabilidade. O coeficiente da variável preço do pescado $\left(P_{t}\right)$ é significativo a $11 \%$ de probabilidade. O coeficiente de determinação $\left(\mathrm{R}^{2}\right)$ se mostra elevado (cerca de $83 \%$ ), indicando um bom ajustamento da 
função de demanda, bem como a estatística $\mathrm{F}$, indicando elevado nivel de significância da regressão.

A elasticidade-preço da demanda do pescado $\left(\varepsilon^{d}\right)$, da ordem de $-0,4322$, indica que um aumento de $10 \%$ no preço do pescado reduzirá em $4,3 \%$ a quantidade demandada de pescado, em condições coeteris paribus. Ao comparar esse valor com os valores do coeficiente de elasticidade-preço da demanda por sardinha, observa-se que o mesmo é menor do que os valores encontrados por Carvalho (1980), igual a $-0,519$; por Okawa (1985), igual a $-1,82$ no curto prazo e $-2,12$ no curtíssimo prazo; e Morimoto (1975), que encontrou um valor igual a $-1,36$. Essa diferença é esperada uma vez que tais estudos consideraram a demanda por uma única espécie de peixe, enquanto a demanda do presente estudo diz respeito a todo pescado consumido.

A elasticidade-renda da demanda do pescado $(\eta)$ foi estimada, nesse estudo, em 0,2874 , sugerindo um incremento na demanda do produto da ordem de $2,9 \%$, quando a renda per capita do consumidor cresce de $10 \%$. Observa-se que esse valor da elasticidade-renda permite considerar como sendo relativamente pequena a utilidade marginal da renda e, portanto, o cálculo do excedente do consumidor realizado nesse estudo (estimado através da curva de demanda ordinária) será bem próximo do excedente do consumidor de Hicks (estimado através da curva de demanda compensada).

O coeficiente referente à variável $P B_{t}$ (preço da carne de boi - bem substituto), 0,3705 , indica que para uma variação de $10 \%$ no preço da carne de boi, a quantidade demandada de pescado varia $3,7 \%$, no mesmo sentido.

Os sinais dos coeficientes de regressão da equação de oferta estão coerentes com a teoria econômica. Os coeficientes estimados foram significativos a $1 \%$ de probabilidade. $O$ coeficiente de determinação $\left(R^{2}\right)$ e a estatística $F$ indicam um bom ajustamento da função de oferta do pescado.

A elasticidade-preço da oferta do pescado $\left(\varepsilon^{\delta}\right)$ foi de 0,4243 , indicando que uma variação de $10 \%$ no preço do pescado conduz à variação de $4,2 \%$ na quantidade ofertada de pescado, no mesmo sentido. 
O coeficiente da variável "incentivos fiscais" $(0,0113)$ indica que concessões de incentivos fiscais à pesca afetam positivamente a quantidade ofertada do pescado brasileiro, mas com pequena influência, pois $10 \%$ de acréscimo nos incentivos fiscais aumentam a quantidade ofertada de $0,11 \%$.

\subsection{Cálculo do benefício e do custo social dos incentivos fiscais concedidos à atividade pesqueira no Brasil.}

Para calcular o Benefício Social Total (BST) da concessão de incentivos fiscais à atividade pesqueira, conforme o modelo apresentado no item 2.2 do capítulo 2, foram usadas as seguintes equações:

$$
\mathrm{BST}=0,5 K P_{0} Q_{0}\left(1+Z \varepsilon^{d}\right) \quad(1) \quad \begin{aligned}
& \text { para o deslocamento pivotal da } \\
& \text { curva de oferta de pescado }
\end{aligned}
$$

ou

$$
\mathrm{BST}=0,5 K P_{0} Q_{0}\left(2+Z \varepsilon^{d}\right) \quad \text { (2) } \quad \begin{aligned}
& \text { para o deslocamento paralelo da } \\
& \text { curva de oferta de pescado }
\end{aligned}
$$

onde:

$K \quad=$ deslocador da curva de oferta e é calculado pela seguinte fórmula;

$$
K=\frac{\left(1-\frac{Q_{0}}{Q_{21}^{s}}\right)}{\varepsilon^{s}} ;
$$

$Q_{2 t}^{S} \quad=$ quantidade de produto ofertado ao nível de preço $P_{0}$, depois de concedidos os incentivos fiscais;

$P_{0}$ e $Q_{0}=$ preço e a quantidade de equilíbrio do pescado oriundo da pesca extrativa e nãoextrativa, respectivamente, antes da concessão de incentivos fiscais à pesca. 
$\varepsilon^{d} \quad=$ elasticidade-preço da demanda do pescado oriundo da pesca extrativa e nãoextrativa (em valor absoluto);

$\varepsilon^{s}=$ elasticidade-preço da oferta do pescado oriundo da pesca extrativa e nãoextrativa;

$$
Z=\frac{K \cdot \varepsilon^{s}}{\left(\varepsilon^{s}+\varepsilon^{d}\right)}
$$

Com base nas estimativas das equações de demanda e oferta de pescado no Brasil (ilustradas no item anterior), tem-se que $\varepsilon^{d}=0,4322$ e $\varepsilon^{s}=0,4243$.

$\mathrm{O}$ valor de $K$ é calculado para cada ano, sendo que a cada ano tem-se um valor distinto de $Q_{2 t}^{S}$. Considerando o ano de 1966 como sendo o período zero (pois é o primeiro ano anterior à concessão de incentivos fiscais à pesca), tem-se a seguinte equação para calcular $Q_{2 t}^{S}$ para cada ano:

$$
\mathrm{L} Q_{2 t}^{S}=1,6856+0,4243 \cdot \mathrm{L} P_{t}+0,0113 \cdot \mathrm{L} I F_{t-k}
$$

Através da equação (10), mede-se o deslocamento da curva de oferta de pescado, advindo dos incentivos fiscais.

De posse dos valores anuais distintos de $Q_{2 t}^{S}$ [obtidos da equação (10)] e utilizando os dados da Tabela 8 , obtém-se os valores anuais de $K$ (Tabela 9). Com os valores anuais distintos de $K$, e com as elasticidades-preço da demanda $\left(\varepsilon^{d}\right)$ e da oferta $\left(\varepsilon^{s}\right)$, calculam-se os valores de $Z$ (Tabela 9).

Enfim, com os valores anuais de 1967 a 1986 de $K, Z$, com $\varepsilon^{d}, P_{0}$ e $Q_{0}$, calculam-se os valores anuais do beneficio social total obtido com os incentivos fiscais, tanto para o caso do deslocamento pivotal, como para o caso do deslocamento paralelo da curva de oferta (Tabela 9). Maiores detalhes sobre os procedimentos de cálculos podem ser vistos no Apêndice $\mathrm{C}$. 
Tabela 9 : Benefício Social Total (BST) e Custo Social Total (CST) do programa de incentivos fiscais à pesca. 1967 a 1986.

\begin{tabular}{|c|c|c|c|c|c|}
\hline ANOS & $\mathrm{K}$ & $z$ & $\begin{array}{l}\text { BST pivotal } \\
\text { [R\$ago/84] }\end{array}$ & $\begin{array}{c}\text { BST paralelo } \\
\text { [R\$ago/84] }\end{array}$ & $\begin{array}{c}\text { CST } \\
{[R \$ a g o / 84]}\end{array}$ \\
\hline 1967 & 0,1854 & 0,0919 & $39.160 .691,86$ & $76.826 .370,75$ & $16.072 .329,35$ \\
\hline 1968 & 0,2181 & 0,1081 & $47.719 .973,61$ & $93.311 .116,40$ & $61.810 .937,94$ \\
\hline 1969 & 0,2438 & 0,1208 & $55.171 .472,61$ & $107.606 .139,04$ & $180.679 .397,49$ \\
\hline 1970 & 0,2478 & 0,1228 & $57.722 .261,40$ & $112.536 .756,05$ & $213.618 .603,87$ \\
\hline 1971 & 0,2375 & 0,1176 & $56.567 .115,46$ & $110.397 .771,77$ & $138.422 .250,40$ \\
\hline 1972 & 0,2238 & 0,1109 & $54.476 .862,36$ & $106.463 .314,65$ & $78.188 .630,07$ \\
\hline 1973 & 0,2191 & 0,1085 & $54.603 .857,85$ & $106.761 .538,43$ & 64.325 .752 .21 \\
\hline 1974 & 0,2078 & 0,1030 & $52.962 .365,91$ & $103.668 .740,67$ & $40.372 .888,48$ \\
\hline 1975 & 0,2097 & 0,1039 & $54.776 .964,06$ & $107.200 .873,73$ & $43.561 .258,02$ \\
\hline 1976 & 0,2039 & 0,1010 & $54.524 .919,16$ & $106.769 .416,71$ & $34.325 .725,06$ \\
\hline 1977 & 0,2004 & 0,0993 & $54.869 .156,72$ & $107.481 .621,81$ & $29.675 .713,51$ \\
\hline 1978 & 0,1958 & 0,0970 & $54.902 .505,69$ & $107.596 .132,12$ & $24.616 .074,43$ \\
\hline 1979 & 0,1947 & 0,0965 & $55.924 .865,66$ & $109.612 .241,65$ & $23.495 .159,76$ \\
\hline 1980 & 0,1818 & 0,0901 & $53.380 .900,08$ & $104.762 .154,49$ & $13.866 .656,98$ \\
\hline 1981 & 0,1779 & 0,0882 & $53.218 .469,68$ & $104.483 .984,26$ & $11.855 .446,75$ \\
\hline 1982 & 0,1717 & 0,0851 & $52.279 .091,82$ & $102.704 .488,78$ & $9.201 .719,78$ \\
\hline 1983 & 0,1759 & 0,0872 & $54.649 .669,77$ & $107.315 .547,16$ & $10.929 .973,55$ \\
\hline 1984 & 0,1688 & 0,0836 & $53.365 .404,41$ & $104.869 .497,43$ & $8.178 .094,39$ \\
\hline 1985 & 0,1639 & 0,0812 & $52.765 .583,68$ & $103.742 .303,49$ & $6.707 .685,64$ \\
\hline 1986 & 0,1608 & 0,0797 & $52.738 .524,75$ & $103.721 .618,10$ & $5.921 .255,53$ \\
\hline TOTAL & & & $1.065 .780 .656,55$ & $2.087 .831 .627,50$ & $1.014 .593 .576,56$ \\
\hline
\end{tabular}

Fonte: Dados da pesquisa, onde os valores de K, Z e BST foram calculados com base na equação para calcular $Q_{2 t}^{S}$ e com os dados da Tabela 8; os valores de CST foram retirados da Tabela 1.

Pode-se observar pelos dados da Tabela 9 que os beneficios sociais obtidos com os incentivos fiscais são superiores aos custos sociais destes incentivos. Para todo o período de 1967 a 1986 os beneficios sociais, conforme o deslocamento pivotal, foram da ordem de R\$ 1.065.780.656,55 e conforme o deslocamento paralelo, esses benefícios atingiram $\mathrm{R} \$ 2.087 .831 .627,50$. Os custos sociais dos incentivos fiscais foram da ordem de R\$1.014.593.576,56. Portanto, a relação benefício-custo foi de no mínimo 1,05 a no máximo 2,06 .

Os valores das elasticidades podem explicar a existência de grande beneficio social quando a curva de oferta se desloca para a direita. Quando as curvas de demanda e oferta são inelásticas, o deslocamento da curva de oferta para a direita faz com 
que o excedente do consumidor aumente mais do que uma possivel redução do excedente do produtor.

Através da Figura 9 são identificadas as variações no excedente econômico, tanto do consumidor como do produtor, a partir do deslocamento da curva de oferta. Quando do deslocamento da curva de oferta de $S_{0}$ para $S_{1}$, o acréscimo do excedente do consumidor é representado pela soma das áreas $(\mathbf{a}+\mathbf{b})$, representando um ganho de beneficio do consumidor. O ganho de beneficio do produtor é a área $\mathbf{d}$. Entretanto, o produtor, que possuía antes da política de incentivos fiscais, uma área de excedente igual a $(\mathbf{a}+\mathbf{c})$, com o efeito do deslocamento da curva de oferta, perde um excedente econômico representado pela área $\mathbf{a}$. Independente da posição do produtor ( $\mathbf{d} \geq$ ou $\leq \mathbf{a})$, no conjunto o excedente econômico passa de $(\mathbf{e}+\mathbf{a}+\mathbf{c})$ para $(\mathbf{e}+\mathbf{a}+\mathbf{c}+\mathbf{b}+\mathbf{d})$.

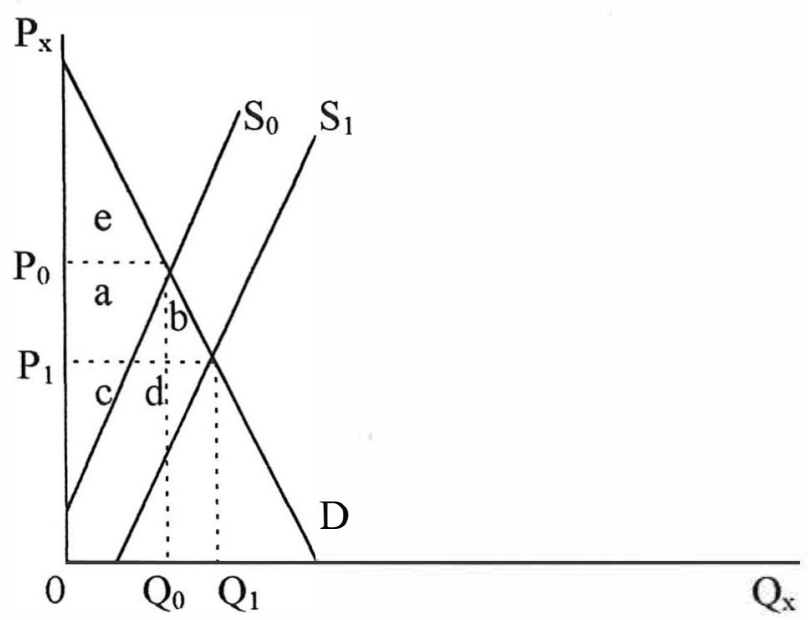

Figura 9 - Ganhos e perda do excedente econômico a partir do deslocamento da curva de oferta de pescado.

Nota: $S_{0}$ e $S_{1}$ rep resentam, respectivamente, as curvas de oferta do pescado antes e após a concessão de incentivos fiscais à pesca; $\mathrm{D}$ representa a curva de demanda do pescado; $\mathrm{P}_{0}$ e $\mathrm{Q}_{0}$ são, respectivamente, o preço e quantidade de equilibrio do pescado antes da concessão de incentivos fiscais à pesca; $\mathrm{P}_{1}$ e $\mathrm{Q}_{1}$ são, respectivamente, o preço e a quantidade de equilibrio do pescado apos a concessão de incentivos fiscais à pesca.

Quanto à relação beneficio-custo do programa de incentivos à pesca, considerando tanto um deslocamento pivotal como um deslocamento paralelo da curva de 
oferta do pescado, nota-se que para os anos específicos de 1969, 1970 e 1971 (anos de grandes volumes de incentivos fiscais), os custos sociais desse programa superaram os beneficios. Observa-se que, à medida que menos incentivos fiscais foram sendo dados à pesca (a partir de 1972), os beneficios sociais ultrapassaram os custos sociais.

Com base nos conceitos de excedente econômico do consumidor e do produtor, os resultados acima mostram que o programa de incentivos fiscais à pesca apresentou beneficios sociais superiores aos custos. Entretanto, apesar de permitir mensurar os beneficios sociais advindos da política de concessão de incentivos fiscais à pesca, esse tipo de cálculo não avalia os efeitos multiplicadores sobre a economia resultantes desses incentivos, e nem os efeitos diretos sobre o segmento industrial, a geração de renda e emprego. Esses últimos efeitos são parcialmente analisados no capítulo seguinte. 


\section{IMPACTOS DO PROGRAMA DE INCENTIVO FISCAL À PESCA SOBRE O SEGMENTO INDUSTRIAL DO SISTEMA AGROINDUSTRIAL DO PESCADO, SOBRE O VALOR DA PRODUÇÃO PESQUEIRA E NA GERAÇÃO DE EMPREGO}

Complementando a análise convencional beneficio-custo feita no capítulo anterior, avalia-se, no presente capítulo, a contribuição desses incentivos à expansão do segmento industrial processador do Sistema Agroindustrial do Pescado ${ }^{26}$, à expansão do valor da produção e do emprego na atividade pesqueira.

\subsection{A evolução do segmento industrial do Sistema Agroindustrial do Pescado}

A análise da evolução da estrutura produtiva do Sistema Agroindustrial do Pescado (que envolve a atividade pesqueira, que compreende a captura e venda do peixe, atividades fornecedoras de insumos à pesca, e as atividades de industrialização e comercialização do pescado), ao longo dos anos, permite avaliar os efeitos da política de incentivos fiscais sobre esse sistema. Não obstante, a restrição de dados disponíveis permite apenas avaliar a evolução do segmento industrial e da atividade pesqueira desse Sistema Agroindustrial.

O segmento industrial do Sistema Agroindustrial do Pescado consititu-se dos estabelecimentos industriais de preparação e fabricação do pescado, envolvendo os entrepostos de pescados, as unidades de preparação e fabricação de conserva do pescado, os barcos-fábrica, incluindo nesse contexto o setor de

\footnotetext{
${ }^{26}$ Trata-se da parte do Sistema Agroindustrial do Pescado (SAG Pescado) que processa o pescado. Para efeito de simplificação, será denominado apenas de segmento industrial do SAG Pescado.
} 
transformação, que envolve o corte, a filtragem, a salga, a secagem, a defumação, o cozimento, o congelamento e o enlatamento de matéria-prima.

Conforme dados do Recenseamento Industrial do Brasil de 1960, em 1959 existiam 141 estabelecimentos industriais de preparação e fabricação do pescado registrados no Brasil. Pela Tabela 10, constata-se que esses estabelecimentos, em 1970, totalizavam 174. Nesse intervalo de 11 anos, o número de estabelecimentos industriais de preparação e fabricação de pescado no Brasil cresceu em torno de 23,4\%, com uma taxa de crescimento média anual de 1,93\%. Deve-se considerar que, nos últimos quatro anos do período analisado (de 1967 a 1970) havia uma política de incentivos fiscais à pesca, que proporcionou recursos de $\mathrm{R} \$ 472,18$ milhões (a preços de agosto de 1994) para desenvolver o setor pesqueiro no país.

Tabela 10 - Número de estabelecimentos e valor da produção do grupo de indústrias que produzem alimentos, do subgrupo que prepara o pescado e fabrica conservas do pescado no Brasil, em 1970, 1975,1980 e 1985.

\begin{tabular}{|c|c|c|c|c|c|c|c|c|}
\hline \multirow[b]{2}{*}{ Indústria } & \multicolumn{2}{|c|}{1970} & \multicolumn{2}{|c|}{1975} & \multicolumn{2}{|c|}{1980} & \multicolumn{2}{|c|}{1985} \\
\hline & $\begin{array}{l}\text { Estabele- } \\
\text { cimentos }\end{array}$ & $\begin{array}{l}\text { Valor da } \\
\text { Produção }\end{array}$ & $\begin{array}{l}\text { Estabele- } \\
\text { cimentos }\end{array}$ & $\begin{array}{l}\text { Valor da } \\
\text { Produção }\end{array}$ & $\begin{array}{l}\text { Estabele- } \\
\text { cimentos }\end{array}$ & $\begin{array}{c}\text { Valor } \\
\text { Produção }\end{array}$ & $\begin{array}{l}\text { Estabele- } \\
\text { cimentos }\end{array}$ & $\begin{array}{l}\text { Valor } \\
\text { Produção }\end{array}$ \\
\hline Produtos Alimentares (PA) & 17.162 & $18.850,4$ & 24.559 & $33.216,4$ & 24.916 & $26.910,1$ & 43.034 & $28.341,1$ \\
\hline $\begin{array}{l}\text { Preparação e Fabricação de } \\
\text { Conservas do Pescado (PFCP) }\end{array}$ & 174 & 258.25 & 169 & 406,82 & 198 & 393,74 & 272 & 374,82 \\
\hline $\begin{array}{l}\text { Participação percentual do sub- } \\
\text { grupo PFCP no grupo de PA }\end{array}$ & 1,01 & 1,37 & 0,69 & 1,22 & 0,79 & 1,46 & 0,63 & 1,32 \\
\hline
\end{tabular}

Fonte: Censo Industrial do Brasil de 1970, 1975. 1980 e 1985.

Nota: Segundo descrições dos volumes anuais do Censo Industrial, cada estabelecimento representa informações referentes a uma atividade industrial homogênea no detalhamento de subgrupos classificados nos grupos; os dados do "Valor da Produção" estão em R $\$ 1.000 .000,00$ de agosto de 1994.

Tomando por base a Tabela 10 , é possível constatar que no período de 1970 a 1985, em que havia captação de recursos via incentivos fiscais, o número de estabelecimentos industriais de preparação e fabricação de pescado cresceu cerca de 56,3\%, passando de 174 em 1970 para 272 estabelecimentos em 1985. Contudo, esses quinze anos abrangem duas fases distintas. De 1970 a 1975, quando se concedeu um volume anual médio de $\mathrm{R} \$ 73$ milhões de incentivos fiscais, houve concentração na 
atividade de preparação e fabricação de conservas de pescado. O número desses estabelecimentos caiu $2,9 \%$ e o faturamento médio elevou-se em $62 \%$. Foi, portanto, uma fase de concentração das atividades de industrialização do pescado.

No período seguinte (1975 a 1985), onde a concessão de incentivos fiscais à pesca diminuiu (média anual de $\mathrm{R} \$ 17,3$ milhões), ocorreu o fenômeno de desconcentração das atividades de industrialização do pescado. Nesses dez anos, o número de estabelecimentos de preparação e fabricação de conservas do pescado cresceu $61 \%$ e o faturamento médio caiu $43 \%$.

Ao considerar a participação da indústria de preparação e fabricação de conservas de pescado no grupo de indústrias produtoras de alimentos do Brasil, constatase, pela Tabela 10, que tanto em número de estabelecimentos como em valor da produção, essa participação diminuiu. Em 1970, os estabelecimentos produtores e fabricantes de conserva de pescado representavam 1,01\% do total dos estabelecimentos produtores de alimentos no país, reduzindo esse percentual para 0,63\% em 1985 . O mesmo acontece no caso do valor da produção. Em 1970, o valor da produção gerado pelos produtores e fabricantes de conserva do pescado representava $1,37 \%$ do total gerado em todo o setor produtor de alimentos, caindo esse percentual para $1,32 \% \mathrm{em}$ 1985. Esses dados caracterizam a reduzida importância da produção industrial do pescado no setor produtor de alimentos do Brasil.

Ao comparar os dados da Tabela 10, que retratam os estabelecimentos industriais de preparação e fabricação de pescados formados no período em que existia a política de incentivos fiscais à pesca, com dados mais recentes (veja Tabela 11), pode-se constatar que de 1985 a 1995 houve pequeno crescimento do número desses estabelecimentos, ou seja, nesses 10 anos o número de estabelecimentos industriais de preparação e fabricação de pescados cresceu 1,8\%, passando de 272 unidades em 1985 para 277 unidades em 1995, mostrando uma taxa de crescimento bastante reduzida para o período $(0,18 \%$ ao ano $)$.

É importante ressaltar que, conforme dados do Faveret \& Siqueira (1997), em 1986 o número de estabelecimentos industriais de preparação e fabricação de 
pescados registrados no Brasil atingiu o patamar das 300 unidades. Entretanto, conforme parágrafo anterior, em 1995 esse número reduz para 277 estabelecimentos, queda essa atribuída em grande parte à redução no número de fábricas de conserva de pescado. Segundo Faveret \& Siqueira (1997), essa menor dimensão do setor de conservas na produção nacional está relacionada à drástica queda dos estoques de sardinha (como foi mencionado no item 3.2 .2 do capítulo 3 desse estudo), não obstante as importações terem contribuído para manter muitas fábricas funcionando.

Tabela 11 - Número de estabelecimentos industriais de preparação e fabricação de pescado, por Estado, e participação relativa - 1993 e 1995.

\begin{tabular}{|c|c|c|c|c|}
\hline \multirow[b]{2}{*}{ Estado } & \multicolumn{2}{|c|}{1993} & \multicolumn{2}{|c|}{1995} \\
\hline & $\begin{array}{l}\text { Estabelecimentos } \\
\text { (unidades) }\end{array}$ & $\begin{array}{c}\text { Participação } \\
(\%)\end{array}$ & $\begin{array}{l}\text { Estabelecimentos } \\
\text { (unidades) }\end{array}$ & $\begin{array}{c}\text { Participação } \\
(\%)\end{array}$ \\
\hline Santa Catarina & 52 & 18,2 & 55 & 19,8 \\
\hline São Paulo & 56 & 19,6 & 49 & 17,7 \\
\hline Rio Grande do Sul & 31 & 10,8 & 27 & 9,7 \\
\hline Rio de Janeiro & 29 & 10,1 & 26 & 9,4 \\
\hline Ceará & 23 & 8,0 & 19 & 6,8 \\
\hline Outros & 95 & 33,3 & 101 & 36,6 \\
\hline Brasil & 286 & 100 & 277 & 100 \\
\hline
\end{tabular}

Fonte: Dados de 1993 retirados de Giulietti \& Assumpção (1995) e dados de 1995 retirados de Faveret \& Siqueira (1997).

No ano de 1995, dos 277 estabelecimentos industriais de preparação e fabricação de pescados existentes, $71,8 \%$ eram classificados como entreposto de pescado, $23,8 \%$ eram fábrica de conserva de pescado e $4,3 \%$ eram barco-fábrica. Os portos de desembarque, os entrepostos de pescado, bem como os locais de desembarque das próprias indústrias, constituem a estrutura de terra da captura. Entretanto, em entrepostos de pescado realizam-se atividades de preparação do pescado (como a limpeza, o resfriamento, a salga do pescado).

$\mathrm{Na}$ análise da evolução do segmento industrial do Sistema Agroindustrial do Pescado, faz-se necessário uma caracterização da capacidade de produção de seus estabelecimentos industriais. O relatório IPEA/COMIF (1986) destacou estudo realizado pela SUDEPE, em que esse órgão selecionou um número considerável de amostras das empresas de processamento de pescado com maior freqüência na demanda de recursos do 
FISET/Pesca. E constatou que, antes da concessão dos incentivos fiscais, essas empresas apresentavam um grau de utilização da capacidade instalada da ordem de 78\%. Em 1983, após aplicação dos incentivos, o índice de utilização da capacidade produtiva dessas empresas caiu para $12 \%$ em média e observou-se um crescimento de $33 \%$ da capacidade instalada. Entretanto, conforme avaliação realizada pelo IPEA/COMIF (1986), nessa época, a reduzida utilização da capacidade produtiva dessas empresas estava mais relacionada à ineficiência na aplicação dos recursos, bem como à possibilidade dessas empresas terem superestimado a capacidade a ser instalada, do que propriamente à falta de oferta de matéria-prima a ser utilizada na produção. A questão da escassez do recurso pesqueiro torna-se mais relevante a partir de meados dos anos 80, como ficou evidenciado pela tendência decrescente da produção pesqueira nacional a partir de 1986, com a queda da participação da produção marítima em relação à produção de água doce nos últimos anos estudados, bem como a constatação de sobreexploração de algumas espécies (dados esses analisados no capítulo 3 deste estudo).

Em avaliação recente do parque industrial pesqueiro do Brasil, publicada em Outlook (1997), relata-se que este é composto, em grande parte, por empresas que trabalham com produtos que apresentam maior rentabilidade ou valor na pauta de exportação e com diversas linhas de processamento. Outra característica ressaltada é que esse parque possui uma estrutura de beneficiamento comparável às melhores do mundo. Entretanto, é superdimensionado em função do restrito potencial das espécies capturadas ou do potencial produtivo da área de abrangência. Ressalta-se ainda que essas empresas, atualmente, vem operando com elevado nível de ociosidade.

A evolução do segmento industrial processador do Sistema Agroindustrial do Pescado está ligada à concentração regional da produção do pescado. Conforme a análise da produção regional do pescado brasileiro (no item 3.2.3 do capítulo 3 desse estudo), as regiões Sudeste e Sul lideram em quantidade produzida do pescado, no Brasil. Em seguida, a região que mais produz é a Nordeste. São nessas regiões que estão concentradas grande parte dos estabelecimentos industriais processadores do pescado no Brasil. Pela Tabela 11 pode-se observar que, para os anos de 1993 e 1995, os Estados de 
Santa Catarina, São Paulo, Rio Grande do Sul, Rio de Janeiro e Ceará detinham juntos, respectivamente, cerca de $66,7 \%$ e $63,4 \%$ dos estabelecimentos industriais de preparação e fabricação de pescados do Brasil. Esses dados ressaltam uma importante característica da indústria do pescado, ou seja, sua concentração regional acompanhando a distribuição dos estoques pesqueiros.

Conforme Outlook (1997), nas Regiões Sudeste e Sul, há infra-estrutura direcionada para a produção de conservas, principalmente de conservas de sardinha, e produtos resfriados/congelados, voltados em sua maior parte para o mercado interno. Nas Regiões Norte e Nordeste predomina a linha de produção de congelados destinados ao mercado externo.

Nos Estados do Rio Grande do Sul e Santa Catarina está concentrada a produção de pescados congelados. Nos Estados do Rio de Janeiro e São Paulo está concentrada a produção de conservas, principalmente de sardinha, como linha de produção tradicional e, mais recentemente, a indústria de conservas têm diversificado sua produção com atum, camarão, bonito, entre outras espécies (essa diversificação está intimamente relacionada à escassez de sardinha). No Nordeste, o Estado do Ceará sobressai com a produção da lagosta. Além dessa espécie, outras se destacam no Nordeste e no Norte, como o camarão, a piramutaba, o pargo, etc. (Giulietti \& Assumpção, 1995).

A concentração da estrutura industrial de produção do pescado nessas regiões deve ser relacionada ao volume de recursos direcionados a esse segmento do Sistema Agroindustrial do Pescado, captados via política de incentivos fiscais. Até meados de 1985, 98,79\% desses recursos foram aplicados nas regiões Sudeste, Sul e Nordeste (veja item 3.2.3 do capítulo 3 desse estudo), considerando ainda que grande parte desses recursos foram investidos na indústria e na captura (veja item 3.1.2.3 do capítulo 3 desse estudo). 


\subsection{Valor da produção pesqueira}

Pode-se, tambem, avaliar os impactos dos incentivos fiscais sobre o Valor da Produção Pesqueira (VPP). Esse é o produto da quantidade produzida de pescado pelo seu preço unitário. Os incentivos fiscais, a o afetarem a quantidade produzida, podem afetar o VPP, desde que permaneçam constantes os preços.

A análise, a seguir, decompõe-se em duas partes. Primeiro, utiliza-se a equação de oferta de pescado, estimada no capítulo 4, para analisar os efeitos distintos das variáveis que determinam a quantidade produzida. Em seguida, avalia-se a evolução do Valor da Produção Pesqueira (VPP) antes, durante e depois dos incentivos fiscais à pesca (IFP).

A quantidade produzida do pescado no Brasil, advindo em sua maior parte do mar e, portanto, um recurso natural, é função basicamente do preço desse produto e, também, da política governamental implantada para desenvolver essa atividade. Dessa forma, os coeficientes da equação da oferta de pescado, estimados no capítulo anterior, são importantes na medida em que contribuem para identificar a sensibilidade da produção pesqueira às variações tanto do preço do pescado quanto do volume de incentivos fiscais concedidos à pesca. Como ficou demonstrado no capítulo anterior, nessa estrutura de oferta, o preço do pescado mostrou coeficiente menor que a unidade $(0,4243)$, indicando ser preço-inelástica a oferta do pescado, ou seja, variações no preço do pescado afetam menos do que proporcionalmente a quantidade ofertada deste produto. No caso do coeficiente apresentado pelos incentivos fiscais, sua variação positiva indica que aumento no volume de incentivos contribuem para elevar a quantidade ofertada do pescado, embora tenha apresentado um coeficiente pequeno - da ordem de 0,011 (ver item 4.1 do capítulo 4 deste estudo).

Pela Tabela 12 pode-se verificar a taxa de crescimento do Valor da Produção Pesqueira antes da concessão de incentivos fiscais à pesca (período de 1960 a 1966), durante essa concessão (período de 1967 a 1986) e posteriormente, quando não mais existiam esses incentivos (período de 1987 a 1994). Constata-se que, no período anterior à concessão desses incentivos (de 1960 a 1966), a taxa de crescimento média do 
VPP foi de 3,54\%, enquanto durante o período que havia incentivo fiscal (de 1967 a 1986) essa taxa de crescimento média foi de 5,52\%. Já no período posterior à existência de incentivos fiscais para a pesca, a taxa de crescimento do VPP foi negativa (cerca de $2,54 \%$ ). Esses dados indicam que durante a política de incentivos à pesca observa-se, de certa forma, um maior crescimento do valor da produção pesqueira no país, sendo essa política de incentivos ativa nesse sentido, principalmente se comparada à taxa de crescimento da etapa posterior à concessão desses incentivos, quando o valor da produção pesqueira apresenta taxas negativas de crescimento.

Tabela 12 - Taxa média de crescimento do Valor da Produção Pesqueira (VPP), Brasil, 1960 a 1994.

\begin{tabular}{cc}
\hline Período & Taxa média de crescimento do VPP (\%) \\
\hline $1960-1966$ & 3,54 \\
$1967-1986$ & 5,52 \\
$1987-1994$ & $-2,54$ \\
\hline
\end{tabular}

Fonte: Taxas calculadas a partir da série de dados de Valor da Produção Pesqueira do Brasil, retirada do Anuário Estatístico do Brasil, diversos números.

Nota: A taxa média geométrica de crescimento, percentual, é o produto do coeficiente "b", da regressão $\ln V P P=a+b t$, por 100 .

Não obstante, a queda do VPP no período a partir de 1987 ocorreu devido a exaustão dos estoques de peixes, causada, indiretamente, pelos incentivos fiscais. Esses incentivaram a captura e o processamento do pescado, mas não se ativeram à dimensão e crescimento dos estoques de pescado.

Ao longo dos 20 anos de incentivos fiscais concedidos aos empreendimentos pesqueiros, a produção pesqueira no Brasil somou o valor de R \$18.282.506.415,25 (Tabela 13). Desse total, 29,8\% referem-se ao valor da produção pesqueira formado no período inicial da concessão de incentivos fiscais à pesca (período de 1967 a 1974), enquanto 70,2\% referem-se ao valor da produção pesqueira correspondente ao período de 1975 a 1986 (período em que a captação de recursos pesqueiros via incentivos fiscais é decrescente). Não obstante, no período de 1967 a 1974 foram concedidos $78 \%$ do total de incentivos fiscais à pesca e no período de 1975 a 1986 os $22 \%$ restantes. 
Tabela 13 : Valor da Produção Pesqueira (VPP), Brasil, 1960 a 1994.

\begin{tabular}{cccccccc}
\hline ANOS & $\begin{array}{c}\text { VPP } \\
\text { (R\$ago/94) }\end{array}$ & ANO & $\begin{array}{c}\text { VPP } \\
\text { (R\$ago/94) }\end{array}$ & ANO & $\begin{array}{c}\text { VPP } \\
\text { (R\$ago/94) }\end{array}$ & ANO & $\begin{array}{c}\text { VPP } \\
\text { (R\$ago/94) }\end{array}$ \\
\hline 1960 & $\mathbf{2 7 9 . 3 8 8 . 8 9 4 , 6 0}$ & 1970 & $500.059 .087,78$ & 1980 & $1.165 .278 .850,26$ & 1990 & $931.356 .785,33$ \\
1961 & $\mathbf{3 0 2 . 4 3 0 . 4 7 9 , 0 4}$ & 1971 & $714.297 .170,06$ & 1981 & $980.653 .436,17$ & 1991 & $997.053 .538,07$ \\
1962 & $\mathbf{3 8 4 . 6 6 3 . 1 5 1 , 1 8}$ & 1972 & $\mathbf{7 9 6 . 7 6 4 . 1 7 5 , 3 9}$ & 1982 & $1.087 .313 .505,61$ & 1992 & $1.005 .415 .158,66$ \\
1963 & $\mathbf{3 7 9 . 3 9 1 . 2 0 6 , 0 1}$ & 1973 & $1.083 .078 .049,09$ & 1983 & $1.049 .298 .343,31$ & 1993 & $1.034 .043 .881,70$ \\
1964 & $\mathbf{3 1 4 . 0 4 4 . 4 9 7 , 0 5}$ & 1974 & $1.038 .565 .160,36$ & 1984 & $1.165 .532 .583,18$ & 1994 & $1.081 .445 .576,83$ \\
1965 & $361.290 .661,06$ & 1975 & $820.177 .749,96$ & 1985 & $1.209 .334 .189,05$ & & \\
1966 & $\mathbf{3 6 9 . 5 1 7 . 7 4 1 , 0 4}$ & 1976 & $870.447 .804,88$ & 1986 & $1.453 .606 .387,28$ & & \\
1967 & $\mathbf{3 8 0 . 8 1 8 . 4 8 2 , 2 9}$ & 1977 & $825.1009 .25,42$ & 1987 & $1.329 .864 .159,02$ & & \\
1968 & $\mathbf{4 3 5 . 3 0 6 . 4 1 8 , 3 3}$ & 1978 & $861.481 .358,59$ & 1988 & $1.104 .860 .667,98$ & & \\
1969 & 504.316 .881 .18 & 1979 & $1.341 .075 .857,05$ & 1989 & $1.157 .914 .337,10$ & & \\
\hline
\end{tabular}

Fonte: Anuário Estatístico do Brasil, diversos números.

\subsection{Geração de empregos}

Procurando avaliar o impacto do programa de incentivos fiscais à pesca sobre a geração de emprego nessa atividade, expõe-se na Tabela 14 os dados de pessoas ocupadas na atividade pesqueira, segundo os Censos Demográficos. Constata-se que o número de pescadores no Brasil aumentou de 135.268 em 1960 para 148.422 em 1970, 173.055 em 1980 e 281.556 pescadores em 1991. É interessante observar que, enquanto o número de pescadores cresce (nos anos considerados), o número de pessoas ocupadas na agropecuária, produção extrativa vegetal e animal diminuiu a partir de 1970, passando de 12.872.863 pessoas ocupadas nesse setor em 1970 para 12.043.273 pessoas em 1991 .

Tabela 14 - Número de pessoas ocupadas na produção pesqueira no Brasil, por setor de atividade, e participação percentual sobre o total de pessoas ocupadas no País (em 1960, 1970, 1980 e 1991).

\begin{tabular}{lcccc}
\hline \multicolumn{1}{c}{ Ano } & 1960 & 1970 & 1980 & 1991 \\
\hline Pessoal ocupado no Brasil & 22.750 .028 & 29.557 .224 & 42.271 .526 & 55.293 .320 \\
\hline $\begin{array}{l}\text { Pessoal ocupado na agropecuária, produção extrativa } \\
\text { vegetal e animal }\end{array}$ & 12.068 .537 & 12.871 .863 & 12.093 .740 & 12.043 .283 \\
\hline Trabalhadores na aqüicultura & n.d. ${ }^{\text {a }}+$ & n.d. & n.d. & 4.937 \\
\hline Pescadores & 135.268 & 148.422 & 173.055 & 281.556 \\
\hline $\begin{array}{l}\text { Participação percentual dos pescadores no total do } \\
\text { pessoal ocupado no Brasil }\end{array}$ & 0,59 & 0,50 & 0,41 & 0,51 \\
\hline $\begin{array}{l}\text { Participação percentual dos pescadores no total do } \\
\text { pessoal ocupado na agropecuária, produção extrativa } \\
\text { vegetal e animal }\end{array}$ & 1,12 & 1,15 & 1,43 & 2,34 \\
\hline Pessoal ocupado na indústria do pescado & 123 & 2.748 & 5.054 & 5.216 \\
\hline
\end{tabular}

Fonte: Censo Demográfico de 1960, 1970, 1980 e 1991, do Brasil.

a $\lrcorner$ n.d. : não disponíveis 
$\mathrm{O}$ número de pescadores ainda é pequeno quando comparado com o número de pessoas ocupadas nos diversos setores produtivos do Brasil, em particular no setor agropecuário, de produção extrativa vegetal e animal. Nos anos de 1960, 1970, 1980 e 1991 os pescadores representaram, respectivamente, 0,59\%,0,50\%, 0,41\% e $0,51 \%$ do total do pessoal ocupado no Brasil, e $1,12 \%, 1,15 \%, 1,43 \%$ e $12,34 \%$ do total do pessoal ocupado na agropecuária, produção extrativa vegetal e animal.

Pode-se observar ainda que na atividade de aqüicultura não há registros de pessoas ocupadas nos três primeiros anos analisados. Já no ano de 1991, são registrados 4.937 trabalhadores na aqüicultura. Conforme o Censo Demográfico (1991), esses trabalhadores estão locados não apenas no setor agropecuário, de produção extrativa vegetal e animal (como é o caso dos pescadores), mas também em várias atividades setoriais (indústria de transformação, comércio de mercadorias, administração pública, etc.).

$\mathrm{Na}$ Tabela 15 são apresentadas as taxas médias de crescimento, por período, do número de pescadores e do pessoal ocupado na indústria de pescado no Brasil.

Tabela 15 - Taxa média de crescimento do número de pescadores ocupados na agropecuária, produção extrativa vegetal e animal, e do número de pessoas ocupadas na industria do pescado,1960 a 1991.

\begin{tabular}{|c|c|c|}
\hline Período & $\begin{array}{l}\text { Taxa média de crescimento do } \\
\mathrm{n}^{\circ} \text { de pescadores } \\
(\%)\end{array}$ & $\begin{array}{l}\text { Taxa média de cresc. do } \mathrm{n}^{\circ} \\
\text { pessoas ocupado na indústria } \\
\text { de pescado }\end{array}$ \\
\hline $1960-1980$ & 1,18 & 19,36 \\
\hline $1960-1970$ & 0,85 & 32,60 \\
\hline $1970-1980$ & 1,40 & 5,69 \\
\hline $1970-1991$ & 2,95 & 2,95 \\
\hline $1980-1991$ & 4,14 & 0,26 \\
\hline
\end{tabular}

Fonte: Taxas calculadas a partir dos dados do Censo Demográfico do Brasil de 1960, 1970, 1980 e 1991, utilizados na Tabela 15 desse estudo.

$\mathrm{Na}$ Tabela 14 foi constatado que o número de pescadores em 1960 (ano em que não havia política de incentivos fiscais para a pesca) era de 135.268, passando para 148.422 pescadores em 1970. Nesse período, a taxa média de crescimento foi de 0,85\% (Tabela 15), enquanto o número de pessoas ocupadas na industria do pescado, 
para o mesmo período, aumentou significativamente, passando de 123 em 1960 para 2.748 em 1970 (Tabela 14), apresentando uma taxa média de crescimento de 32,6\% para o período (Tabela 15). Nos últimos quatro anos desse período (de 1967 a 1970), foram concedidos como incentivos fiscais à pesca cerca de $\mathrm{R} \$ 472,18$ milhões, ou seja, $46,48 \%$ do total de incentivos fiscais alocados a esse setor ao longo dos anos de 1967 a 1986 . Ao considerar o período de 1970 a 1980, a taxa média de crescimento do pessoal ocupado na industrialização do pescado é de aproximadamente 5,7\% (Tabela 15), período em que foram investidos cerca de $69,37 \%$ do total dos recursos captados via política de incentivos fiscais à pesca. Entretanto, de 1980 a 1991 essa mesma taxa foi de 0,26\% (Tabela 15), caindo de forma significativa a taxa de crescimento de pessoas ocupadas na indústria de pescado no Brasil. Esses dados são justificados quando é considerada a baixa taxa de crescimento do número de estabelecimentos industriais de preparação e fabricação de pescados do Brasil a partir de meados dos anos 80 e sua grande ociosidade. 


\section{CONCLUSÕES}

Este trabalho analisou a evolução da atividade pesqueira no Brasil e avaliou os impactos das políticas federais pesqueiras sobre essa atividade.

A análise histórica das políticas voltadas para a atividade pesqueira no Brasil demonstra que essas atuaram em dois sentidos: estabelecer regulamentações e conceder incentivos à produção.

A política regulamentadora da atividade pesqueira foi diferenciada por dois tipos: aquelas voltadas à institucionalização de órgãos responsáveis pela coordenação da atividade pesqueira e, complementando-as, as regulamentações que instituem o ordenamento pesqueiro.

Até o momento, constatou-se que a política de regulamentação da atividade pesqueira no Brasil preocupou-se, durante muito tempo, com a criação de órgãos para regulamentar a extração do pescado, mas pouco se preocupou em diagnosticar e ampliar o estoque de pescado nacional. Do lado das regulamentações voltadas para o ordenamento pesqueiro, essas se fizeram mais presentes a partir das últimas três décadas.

No Brasil, a atividade pesqueira tomou maior impulso a partir da década de 60, quando o governo criou a Superintendência para o Desenvolvimento da Pesca (SUDEPE). Em 1989 o Governo Federal extinguiu esse órgão e suas atribuições e competência passaram a ser desempenhadas pelo Instituto Brasileiro do Meio Ambiente e dos Recursos Naturais Renováveis (IBAMA), do Ministério do Meio Ambiente, dos Recursos Hídricos e da Amazônia Legal. Cabe ressaltar que compete a esse órgão não apenas desenvolver atividades relativas aos recursos pesqueiros (que eram atribuições 
restritas da SUDEPE), mas também as relativas ao meio ambiente e aos outros recursos naturais renováveis do Brasil.

Quanto à política de ordenamento pesqueiro, no período anterior à criação da SUDEPE não eram tidas como relevantes as regulamentações que estabelecessem regras de acesso aos recursos pesqueiros. Essas regulamentações começaram a fazer parte, ativamente, da política pesqueira nacional a partir do Decreto $\mathrm{n}^{\mathbf{0}} 68.459$ de 01/04/71. Esse último regulamentou a pesca, considerando os aspectos de aproveitamento racional e a conservação dos recursos vivos do mar territorial brasileiro. No entanto, as preocupações com a sustentação dos recursos pesqueiros tomaram maior dimensão nacional a partir da segunda metade da década de 80 , em um contexto de preservação dos recursos naturais renováveis do Brasil e do Mundo.

Analisando a política de incentivo à produção pesqueira, observa-se que os incentivos fiscais concedidos a empreendimentos pesqueiros, de 1967 a 1986, contribuíram significativamente para ampliar a produção nacional de pescado e o parque industrial processador desse produto. A política de incentivo à produção pesqueira iniciou-se em 1967 com a promulgação do Decreto-lei 221. Esse Decreto incluiu essa atividade entre as relacionadas com o desenvolvimento do País, permitindo deduções tributárias para investimentos em projetos pesqueiros. Além disso, o Decreto-lei 221 permitiu a isenção de impostos e taxas federais para a importação de máquinas, equipamentos e instrumentos em geral para a captura, industrialização, transporte e comercialização do pescado. Durante os anos iniciais da política de incentivos fiscais à pesca (de 1967 a 1972), do total dos recursos captados via incentivos fiscais à pesca, 91\% foram investidos na indústria, captura, administração e comercialização, não sendo identificado investimento algum na área de pesquisa e levantamento de dados. Tal evidência confirma, de certo modo, a hipótese levantada neste estudo: a política pesqueira esteve durante muito tempo preocupada com a captura, processamento e comercialização do pescado, pouco atentando à questão do estoque de pescado.

Do total dos recursos captados através de incentivos fiscais pelos empreendimentos pesqueiros, no período de 1967 a 1986, 78\% referem-se a recursos 
captados no período inicial dessa política de incentivos (de 1967 a 1974). Essa grande percentagem reflete uma certa euforia em utilizar tais recursos, resultando em volumes crescentes de captura, na instalação de um parque industrial de qualidade, dando condições de fomentar futuras exportações do pescado brasileiro.

Não obstante, pontos de estrangulamento são identificados, tais como: irregularidades na alocação dos recursos (desvios de recursos para outras atividades), ineficiência com relação à administração dos recursos, falta de planejamento (com escassos investimentos em pesquisa, tecnologia, fiscalização e formação de mão-de-obra especializada) e, um ponto importante, a prioridade dada a projetos que visavam apenas o aumento da produção e exportação. Para se ter uma idéia do efeito dessa última ação, cerca de $82 \%$ de todas as empresas beneficiadas enfrentaram dificuldades devido a falta de matéria-prima. Isto, mais uma vez, confirma a hipótese levantada neste estudo.

Algumas constatações interessantes quanto à evolução da atividade pesqueira no Brasil foram diagnosticadas no presente trabalho:

a) no período de 1960 a 1994, 78\% da produção média do pescado nacional são de origem marítima e $22 \%$ de água doce. Nos anos 90 , a participação do pescado de água doce começa a crescer. Esse comportamento é atribuído, em grande parte, ao aparecimento da sobrepesca e do avanço da aqüicultura. Nesse contexto, tanto a política orientada para regulamentar a exploração racional do recurso pesqueiro como a que concedeu incentivos fiscais ao desenvolvimento da pesca no país são grandemente responsáveis pela sobreexploração do recurso pesqueiro de livre acesso. Entretanto, na década de 90, a atividade aquícola recebeu maiores atenções da política de regulamentação da atividade pesqueira, no sentido de organizar a produção aquícola no Brasil. O crescimento dessa atividade permitirá elevar cada vez mais a produção brasileira de pescado, aliviando as pressões de extinção do recurso pesqueiro de origem marítima.

b) A produção brasileira do pescado nos anos 90 situa-se em torno de 660 a 700 mil toneladas/ano. As regiões que produzem a maior quantidade do pescado no Brasil são Sudeste e Sul, onde predominam produtos de baixo valor unitário. A Região Nordeste 
produz pescado fino e de elevado valor unitário. Essa concentração da produção regional do pescado é fruto da alocação dos incentivos fiscais à pesca sobre as regiões. Constatou-se que as Regiões Sudeste e Sul receberam, juntas, 77,52\%, enquanto a Região Nordeste ficou com $15,27 \%$ do total de incentivos fiscais à pesca captados até o ano de 1985.

c) O Brasil exporta menor quantidade de pescado fino e de alto valor unitário e importa maior quantidade de pescado de menor valor unitário. A grande quantidade importada de pescado no Brasil é reflexo do efeito da política pesqueira nacional sobre o estoque de matéria-prima, uma vez que a implementação dessa política contribuiu para instalar um parque industrial relativamente grande, ativando a demanda pelo pescado de menor valor, matéria-prima básica para as características da indústria nacional, principalmente nas regiões Sudeste e Sul.

Para avaliar o programa de incentivos fiscais à pesca, estimou-se, inicialmente, um modelo tradicional de beneficio-custo baseado nos conceitos de excedente econômico. Constatou-se que os beneficios sociais foram superiores aos custos sociais incorridos no programa em questão. Para cada $\mathrm{R} \$ 1,00$ de incentivo fiscal. concedido, gerou-se beneficio social de $\mathrm{R} \$ 1,05$ a $\mathrm{R} \$ 2,06$.

Reconhecendo que a metodologia tradicional de análise beneficio-custo não abrange todos os impactos causados pelos incentivos fiscais concedidos à pesca, analisou-se, também, os impactos desses incentivos sobre a expansão do segmento industrial processador do Sistema Agroindustrial do Pescado, sobre o valor da produção do pescado e sobre a geração de empregos.

$\mathrm{O}$ número de estabelecimentos industriais de preparação e fabricação do pescado, durante o período de incentivos fiscais, aumentou significativamente, passando de 174 em 1970 para 272 estabelecimentos em 1985, mostrando uma taxa média de crescimento anual de 3\%; enquanto essa taxa entre 1985 e 1995 (período posterior à política de incentivos) foi muito pequena $(0,18 \%)$. Interessante ressaltar que a baixa taxa de crescimento do número de estabelecimentos industriais de preparação e fabricação de pescado após a atuação da política de incentivos fiscais à pesca está relacionada à 
ociosidade do parque industrial pesqueiro que, por sua vez, é consequência, em grande parte, da escassez de matéria-prima.

O exame do comportamento do valor da produção pesqueira e da evolução do emprego na captura e na industrialização do pescado indicou um maior dinamismo dessas duas variáveis no período de existência dos incentivos fiscais à pesca do que no período anterior ou posterior a ele.

A queda do valor da produção e do ritmo de geração de empregos na atividade pesqueira e na atividade industrial a ela vinculada, no período após os incentivos fiscais, está relacionada à sobrepesca de certas espécies de peixes. Por sua vez, essa sobrepesca ocorreu devido a política pesqueira federal.

Dessa exposição, considera-se válida a hipótese desse trabalho, ou seja, a política pesqueira esteve, durante muito tempo, preocupada com a captura, processamento e comercialização do pescado, pouco se atendo à questão do estoque de pescado, levando à sobrepesca de certas espécies de pescado e afetando negativamente, em período recente, a atividade pesqueira e de industrialização do pescado.

De modo a sanar essa situação e garantir a exploração racional dos recursos pesqueiros (evitando sua exaustão), são sugeridas três modificações na política pesqueira federal:

a) ampliar os investimentos em pesquisa e em capital humano, considerando aspectos como: formação de um banco de dados (levantamento estatístico) sobre o setor e a implementação de programas de formação e treinamento de mão-de-obra para ampliação e exploração racional do pescado nacional.

b) ampliar a interrelação entre as políticas de regulamentação do uso de recursos naturais renováveis, de forma a desenvolver conjuntamente atividades que envolvem esses tipos de recursos, explorando-os racionalmente. Por exemplo, interrelacionar políticas que regulam o uso dos recursos pesqueiros, florestais e aquáticos, propiciando o desenvolvimento da atividade da pesca em rios apropriados (sem poluição, com mata ciliar, etc.). Nesse caso, o acesso à pesca pode ser estabelecido por regulamentações que concedam privilégios àqueles que conservam os recursos 
naturais. Esse tipo de política compreende três pontos de ação do IBAMA (água, floresta e pesca). A aqüicultura surge, assim, como alternativa rentável para o país, que pode gerar uma oferta estável no mercado, estabilizando ou diminuindo os esforços de pesca extrativa.

c) Criar mecanismos eficientes de fiscalização da exploração do recurso pesqueiro é crucial à implementação de quaisquer medidas de conservação e exploração racional do recurso pesqueiro, evitando-se, com isso, que o estoque seja explorado além de sua capacidade de sustentação. 


\section{REFERÊNCIAS BIBLIOGRÁFICAS}

AKINO, M.; HAYAMI, Y. Efficiency and equity in public research: rice breeding in japan's economic development. American Journal of Agricultural Economics, v.57, n.l, p.1-10, 1975.

ANDERSON, L.G. An economic analysis of highgrading in ITQ fisheries regulation programs. Marine Resource Economics, v.9, n.3, p.209-226,1994.

ANDERSON, L.G. The economics of fisheries management. Baltimore: The John Hopkins University Press, 1977. 296p.

ANUÁRIO ESTATÍSTICO DO BRASIL - diversos números.

ANUÁRIO ESTATÍSTICO DO INSTITUTO DE ECONOMIA AGRÍCOLA - IEA/SP diversos números.

ARAÍ, A.L. Indústria da pesca terá óleo subsidiado. Gazeta Mercantil. Agribusiness. São Paulo, 19 nov. 1997. P.C-7. 
ARAÚJO, P.F.C.; SILVA, A.M.; OLIVEIRA, J.P.; MACHADO, S.A.; BORELLI, V. Descrição do ensino na área de ciências agrárias. Ministério da Educação e do Desporto e Secretaria de Educação Superior, Brasilia. 1996.

ARNARSON, R. ITQ based fisheries management. Canadian Special Publication of Fisheries and Aquatic Sciences, n.120, p.345-356, 1993.

AYER, H.W.; SCHUH, G.E. Social rates of return and other aspectos of agricultural research: the case of cotton research in São Paulo, Brazil. American Journal of Agricultural Economics, v.56, n.1, p.175-179, 1974.

AZEVEDO, R.; MAYORGA, R. D.; FARIAS, M.A.M. Alguns aspectos do mercado varejista de pescado em Fortaleza. Revista de Economia Rural, v.23, n.3, p.409429, jul./set. 1985.

BACHA, C.J.C. Análise custo-benefício dos programas federais de incentivo ao reflorestamento no Brasil. Piracicaba: ESALQ/USP/CNPq, 1995. 93p. (Relatório de pesquisa).

BACHA, C.J.C. A dinâmica do desmatamento e do reflorestamento no Brasil. Piracicaba, 1993. 236p. Tese (Livre-Docência) - Escola Superior de Agricultura "Luiz de Queiroz", Universidade de São Paulo.

BERTOLOTTI, M.I. Utilizacion de modelos bioeconomicos: ventajas y limitaciones. consulta de expertos sobre el asesoramiento economico a administradores de pesquerias demersales $y$ pelagicas de paises seleccionados de latinoamerica. Montevideo: FAO, 1989. 
BEVERTON, R.J.H.; HOLT, S.J. On the dynamics of exploited fish populations. London: Her Majesty's Stationery Office, 1957. 538p.

BRASIL Ministério do Meio Ambiente, dos Recursos Hídricos e da Amazônia Legal. Projeto Cenários para o Planejamento da Gestão Ambiental. Os ecossistemas brasileiros e os principais macrovetores de desenvolvimento. Brasília, 1996. p.7789.

BRASIL. Diagnóstico: análise do setor pesqueiro do estado de São Paulo. São Paulo: COREG, SUDEPE, 1988.

BRASIL. Plano nacional do desenvolvimento da pesca - 1975/1979. Brasília: SUDEPE, 1975. 2v.

CAMPBELL, D. Individual transferable catch quotas: their role, use and application. Fishery Report, n. 11, 1984.

CARVALHO, F. C.; GIULIETTI, N. Abastecimento de sardinha à população paulistana de baixa renda. Informações Econômicas, v.8, n. 1, p.1-5, 1978a.

CARVALHO, F. C.; GIULIETTI, N. Comercialização e consumo de camarão no Estado de São Paulo. Informações Econômicas, v. 8, n.2, p.1-4, 1978 b.

CARVALHO, F.C. Ciclos na comercialização de sardinha. In: XVIII CONGRESSO BRASILEIRO DE ECONOMIA E SOCIOLOGIA RURAL, 18., Rio de Janeiro, 1980. Anais. Brasilia: SOBER, 1980. p.1-10. 
CARVALHO, F.C.; ARRUDA, C. Comparação analítica da variação estacional no mercado pesqueiro do Estado de São Paulo. Agricultura em São Paulo, v24, n.1, p.113-117, 1980.

CHABALIN, E. Análise econômica da criação de peixes sob condições de risco: estudo de caso do pacu. Piracicaba, 1996. 62p. Dissertação (Master Science) - Escola Superior de Agricultura "Luiz de Queiroz", Universidade de São Paulo.

CLARK, C.W. Bioeconomic modelling and fisheries management. New York: Wiley - Interscience, 1985. 291p.

CLARK, C.W. Bioeconomic modeling and resource management. In: LEVIN, S.A.; HALLAM, T.G.; GROSS, L.J. (Ed.). Applied mathematical ecology. New York: SpringerVerlag, 1989. p.11-57.

CLARK, I.N.; MAJOR, P.J. Development in implementation of New Zeland's ITQ management system. Marine Resource Economics, v.5, n.4, p.325-349, 1988.

CONJUNTURA ECONÔMICA - IBGE, Rio de Janeiro, junho. 1977.

CRUZ, P.R.D.C. Projeção da demanda de produtos hortifrutigranjeiros e de pescado para a região metropolitana de São Paulo. Planejamento e Conjuntura, v.72, n.1, p.67-73, jan. 1974.

DEFESA DA LAGOSTA: a produção da lagosta pode acabar. INSTITUTO BRASILEIRO DO MEIO AMBIENTE E DOS RECURSOS NATURAIS RENOVÁVEIS. http://www.ibama.gov.br, Brasília, 1998. 
DIEGUES, A.C.S. Povos e mares: leitura em sócio-antropologia marítima. São Paulo: NUPAUB/USP, 1995. p.51-84.

FAVERET FILHO, P.; SIQUEIRA, S. H. Panorama da pesca marítima no Mundo e no Brasil. BNDES Setorial, n. 5, mar. 1997.

FERREIRA, A.C.M. Variação estacional de preços de pescados na cidade de São Paulo. Piracicaba, 1980. 152p. Dissertação (Mestrado) - Escola Superior de Agricultura "Luiz de Queiroz", Universidade de São Paulo.

FERREIRA, G.A. Aspecto da comercialização do pescado da colônia de pesca da baleia; Itapipoca. Fortaleza, 1979. Monografia (Graduação) - Universidade Federal do Ceará.

FERREIRA, M.M. Retorno aos investimentos em pesquisa e assistência técnica na cultura do café em Minas Gerais. Viçosa, 1993. Dissertação (Master Science) Universidade Federal de Viçosa.

FONSECA, M.A.A.S. Retorno social aos investimentos em pesquisa na cultura do café. Piracicaba, 1976. 148p. Dissertação (Master Science) - Escola Superior de Agricultura “Luiz de Queiroz", Universidade de São Paulo.

GALLO, J. Participação dos entrepostos de pesca e pontos de desembarque no abastecimennto da cidade de São Paulo. Série Teses e Monografias, n.23, 1976. (IGEOG-USP).

GIULIETTI, N.; ASSUMPÇÃO, R. Indústria pesqueira no Brasil. Agricultura em São Paulo, v.42, n.2, p. 95-127, 1995. 
GORDON, S.H. Economic theory of a common-property resource: the fishery. Journal of Political Economy, v.62, n.1, p.124-142, 1954.

GRILICHES, Z. Research cost and social returns: hybrid corn and related innovations. Journal of Political Economy, v.66, n.1, p.9-31, 1958.

HANNESSON, R. The political economy of individual tranferable quotas. In: SYMPOSIUM ON FISHERIES MANAGEMENT-GLOBAL TRENDS, Seattle: Uninersity of Washington, 1994.

HANNESSON, R. Optimal catch capacity and fishing efort in deterministic and stochastic fishery models. Fisheries Researach, n.5, 1987.

HICKS, J.R. Valor e capital: estudo sobre alguns princípios fundamentais da teoria econômica. São Paulo: Abril Cultural, 1984. 276p. (Os Economistas).

HOFFMANN, R.; VIEIRA, S. Análise de regressão: uma introdução a econometria. 3.ed. São Paulo: Hucitec, 1997. 335p.

IMF. International Financial Statistics Yearbook. Washington: 1997.

INSTITUTO BRASILEIRO DE GEOGRAFIA E ESTATÍSTICA. Censo demográfico do Brasil. Rio de Janeiro: IBGE, 1960, 1970, 1980, 1991.

INSTITUTO BRASILEIRO DE GEOGRAFIA E ESTATÍSTICA. Censo industrial do Brasil. Rio de Janeiro: IBGE, 1970, 1975, 1980, 1985. 
INSTITUTO BRASILEIRO DE GEOGRAFIA E ESTATÍSTICA. Recenseamento do Brasil. Rio de Janeiro: IBGE, 1960.

IPEA/COMIF. Relatório de avaliação dos incentivos fiscais regidos pelo decreto-lei $n^{0}$ 1.376, de 12 de dezembro de 1974. Instituto de Planejamento Econômico e Social e Comissão de Avaliação de Incentivos Fiscais, Brasília. 1986.

KMENTA, J. Elementos de econometria. São Paulo: Atlas, 1978. 670p.

LEGISLAÇÕES DO INSTITUTO BRASILEIRO DO MEIO AMBIENTE E DOS RECURSOS NATURAIS RENOVÁVEIS. http://www.ibama.gov.br. (22 abr. 1998).

LINDNER, R.K.; JARRET, F.G. Supply shifts and the size of research benefits. American Journal of Agricultural Economics, v.60, n.1, p.48-56, 1978.

LINHAS DE ATUAÇÃO DO INSTITUTO BRASILEIRO DO MEIO AMBIENTE E DOS RECURSOS NATURAIS RENOVÁVEIS. http://www.ibama.gov.br. (29 ago. 1998).

MARSHALL, A. Princípios de economia: tratado introdutório. São Paulo: Abril Cultural, 1982. 2v. (Os Economistas).

MARTINS, E. O princípio da responsabilidade ambiental. Leis de Crimes Ambientais. INSTITUTO BRASILEIRO DO MEIO AMBIENTE E DOS RECURSOS NATURAIS RENOVÁVEIS. http://www.ibama.gov.br. (29 ago. 1998). 
MCKELVEY, R. Common property and the conservation of natural resources. In: LEVIN, S.A.; HALLAM, T.G.; GROSS, L.J. (Ed.) Applied Mathematical Ecology. New York: SpringerVerlag, 1989. p. 58-80.

MISHAN, E.J. Análise de custos-benefícios: uma introdução informal. Rio de Janeiro: Zahar, 1976. $488 \mathrm{p}$.

MISHAN, E.J. What is producer's surplus? The American Economic Review, v.58, n.5, p.1269-1283, 1968.

MONTEIRO, A. Avaliação econômica da pesquisa e extensão agrícola: o caso do cacau no Brasil. Viçosa, 1975. 75p. Dissertação (Master Science) - Universidade Federal de Viçosa.

MONTOYA, M.A.R.; PARRÉ, J.L.; GUILHOTO, J.J.M. Mercosul: os custos e beneficios intersetoriais na agroindustria e na economia brasileira derivados da competitividade na produção de grãos entre Argentina e Brasil. In: MONTOYA, M. A.R. (Org.). Relações intersetoriais do mercosul e da economia brasileira: uma abordagem de equilíbrio geral do tipo insumo-produto. Passo Fundo: Editora da UPF, 1998.

MORAeS, J.R. Distribuição ou consumo de pescado. Revista Nacional da Pesca, v.9, n.74, 1968.

MORIMOTO, P.T. Demanda de pescado no mercado da grande São Paulo. Viçosa, 1975. 40p. Dissertação (Master Science) - Universidade Federal de Viçosa. 
MOTTA, R.S. Um estudo de custo-beneficio do proálcool. Pesquisa e Planejamento Econômico, v.17, n.1, p.65-92, abr. 1987.

NEIVA, G.S. Subsídios para a política pesqueira nacional. Santos: Terminal Pesqueiro, 1990.

NORTON, G.W.; DAVIS, J.S. Evaluating returns to agricultural research: a review. American Journal of Agricultural Economics, v.63, n.4, p.685-699, 1981.

OKAWA, H. Análise harmônica das variações dos preços e das quantidades de sardinha fresca no mercado atacadista de São Paulo - 1981/82. Piracicaba, 1985. 96p. Dissertação (Master Science) - Escola Superior de Agricultura "Luiz de Queiroz", Universidade de São Paulo.

OUTLOOK: Perspectivas mercosur sobre carnes, leche, pescado y lana. In: Relatório do Seminário. Sala de Conferencia del Instituto Nacional de Pesca.. Montevidéu. Uruguay. 1997.

PAEZ, M.L.D. An economic analysis of some factors associated with the intemational trade of frozen groundfish blocks. Corvallis. Oregon, 1981. Thesis (Doctorate). Oregon State University.

PAEZ, M.L.D. Exploração de recursos pesqueiros no Brasil. Revista de Administração, v.28, n.4, p.51-61, out./dez. 1993.

PAEZ, M.L.D. Produção sustentável dos recursos pesqueiros: propriedade comum ou privada?. Revista de Economia e Sociologia Rural, v.29, n.2, p.95-102, abr./jun 1991. 
PEARSE, P.H. Fishing rights, regulations and revenues. Marine Policy, p.135-146, apr. 1981.

PELLA, J.J.; TOMLINSON, P.K. A generalized stock production model. InterAmerican Tropical Tuna Bulletin, n.13, p.421-458, 1969.

PETERSON, W.L. Returns poultry research in the United States. Journal Farm Economic, v.49, n.3, p.656-669, 1967.

PINSTRUP-ANDERSEN, P.; LONDONO, R.; HOOVER, E. The impact of increasing food supply on human nutrition: implications for commodity priorities in agricultural research and policy. American Journal of Agricultural Economics, v.58, n.2, p.131-142, 1976.

RANDALL, A. Resource Economics. New York: John Wiley \& Son, 1987. 434p.

ROSE, F. Supply shifts and the size of research benefits: comment. American Journal of Agricultural Economics, v.62, n.4, p.834 -837, 1980.

SANTANA, A.C.; KHAN, A.S. Custo social da depredação florestal no Opará: o caso da castanha-do-Brasil". Revista de Economia e Sociologia Rural, v.30, n.3, p.253269, jul./set. 1992.

SCHAEFER, M.B. Some aspects of the dynamics of population important to the management of commercial marine fisheries. Inter-American Tropical Tuna Bulletin, n. 1, p.25-65, 1954. 
SCHULTZ, T.W. The economic organization of agriculture. New York: McGrawHill Book, 1953. 374p.

SCOTT, A. The fishery: the objectives of sole ownership. Journal of Political Economics, n.63, p.116-124, 1955.

SEIJO, R.C.; DEFEO, O.; SALAS, S. Bioeconomia pesquera: teoria, modelacion y manejo. EXPOMEX Serie Científica, n.6, 1996.

SHORT, D.J. Targeting emerging seafood market. Infofish Marketing Digest, n.3, 1987.

SILVA, A.S.; KHAN, A.S. Beneficios sociais da substituição de milho por raspa de mandioca em ração suína, no Estado do Ceará. Revista de Economia e Sociologia Rural, v.32, n.1, p.87-98, jan./mar.1994.

SILVA, C.R.L. Inovação tecnológica na agricultura brasileira: aspectos distributivos. São Paulo, 1992. 215p. Tese (Doutorado) - Faculdade de Economia, Administração, Univerdade de São Paulo.

TOURINHO, O.A.F., FERREIRA, L.R.; PIMENTEL, R.F. Agricultura e produção de energia: um modelo de programação linear para avaliação do proálcool. Pesquisa e Planejamento Econômico, v.17, n.1, p.19-64, abr. 1987.

TREMEL, E. Pesca, novos rumos. Ciclo de palestras sobre temas relacionados ao poder marítimo. Ministério da Marinha, Comando do Quinto Distrito Naval. Florianópolis, 1993. 
TROADEC, J.P. Introducción a la ordenación pesquera: su importancia, dificultades y métodos principales. FAO:Documento Técnico da Pesca, n.224, 60p., 1983.

TWEETEN, L. Farm policy analysis. Boulder: Westview Press, 1989. 399p.

WELLMANN, K.F. Chicken of the sea? the U.S. consumer retail demand for fish products. In: CONFERENCE OF THE INTERNATIONAL INSTITUTE FISHERIES ECONOMICS AND TRADE, 5., Santiago, 1990.

WORKSHOP PARA SUBSIDIAR A CAPACITAÇÃO DE RECURSOS HUMANOS E A GERAÇÃO DE TECNOLOGIA EM AQUICULTURA SUSTENTÁVEL, São Carlos, 1995. Aquicultura para o ano 2000. Brasilia: CNPq, 1996. 95p. 


\section{APÊNDICE A}

\section{DESENVOLVIMENTO DO MODELO DE CÁLCULO DO BENEFÍCIO SOCIAL COM BASE NOS CONCEITOS DE EXCEDENTE DO CONSUMIDOR E DO EXCEDENTE DO PRODUTOR}

Desenvolve-se, nesse tópico, as equações utilizadas para cálculo do beneficio social, seguindo o modelo desenvolvido por Lindner e Jarrett (1978) e aperfeiçoado por Rose (1980). Assim, parte-se de uma apresentação das derivações das áreas, apresentadas por Rose (1980), que identificam o aumento do excedente econômico total.

Rose (1980) demonstra graficamente a área de aumento no excedente econômico advindo de um deslocamento paralelo da curva de oferta. Isso pode ser observado pela Figura 1A.

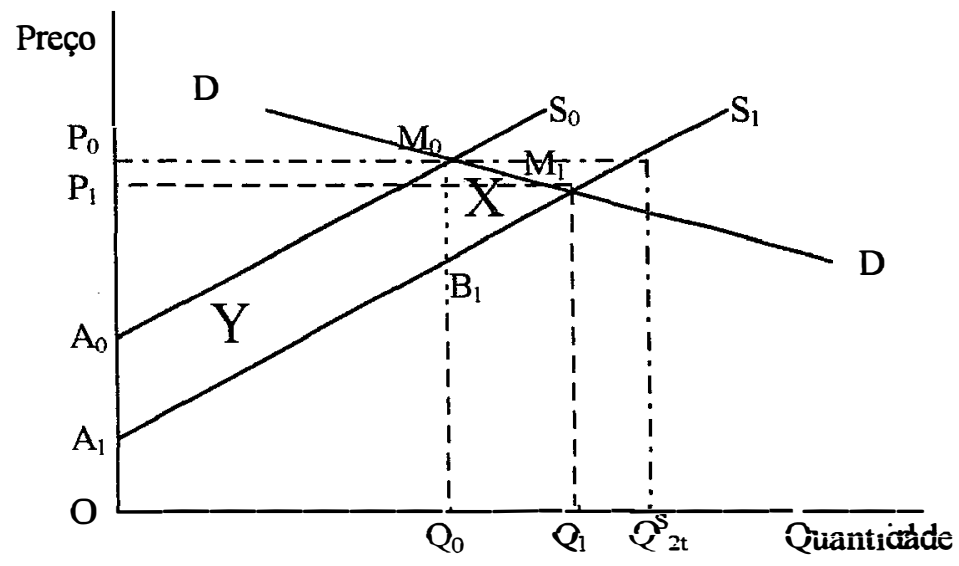

Figura 1A - Demonstração geométrica do benefício social causado pelo deslocamento da curva de oferta agregada 
Seguindo Rose (1980), para uma mudança paralela na curva de oferta (de $S_{0}$ - antes da inovação tecnológica - para $S_{1}$ - após uma inovação tecnológica), a área que representa o aumento do excedente econômico, ou beneficio total, pode ser estimada separadamente, ou seja, somando $\mathrm{M}_{0} \mathrm{M}_{1} \mathrm{~B}_{1} \mathrm{M}_{0}(\mathrm{X})$ com $\mathrm{A}_{0} \mathrm{M}_{0} \mathrm{~B}_{1} \mathrm{~A}_{1} \mathrm{~A}_{0}(\mathrm{Y})$, especificando de forma clara o valor de $\mathrm{M}_{0} \mathrm{~B}_{1}$, que representa a mudança no custo unitário devido ao deslocamento da curva de oferta. Assim, o beneficio total é dado pela equação abaixo:

$$
\mathrm{BST}=\mathrm{X}+\mathrm{Y}
$$

A operacionalização do cálculo das áreas X e Y é apresentada a seguir.

Tomando o ponto de coordenadas $\left(Q_{2 t}^{s}, P_{0}\right)$ na Figura $1 \mathrm{~A}$, tem-se que a elasticidade-preço da oferta $(\varepsilon)$ é:

$$
\varepsilon^{s}=\frac{\left(\frac{Q_{2 t}^{s}-Q_{0}}{Q_{2 t}^{s}}\right)}{\left(\frac{M_{0} B_{1}}{P_{0}}\right)}
$$

Denominando de $K$ como a mudança proporcional do custo unitário, dado um deslocamento da curva de oferta, essa variável pode-se ser calculada como sendo:

$$
K=\frac{\overline{M_{0} B_{1}}}{P_{0}}
$$

Substituindo a expressão (3a) em (2a), tem-se:

$$
\varepsilon^{s}=\frac{\left(1-\frac{Q_{0}}{Q_{2 t}^{s}}\right)}{K} \quad \therefore \quad K=\frac{\left(1-\frac{Q_{0}}{Q_{2 t}^{s}}\right)}{\varepsilon^{s}}
$$


Da expressão (3a), tem-se:

$$
K \cdot P_{0}=\overline{M_{0} B_{1}}
$$

Com esses dados, pode-se agora determinar a expressão algébrica das áreas $\mathrm{X}$ e $\mathrm{Y}$, chegando assim à expressão do aumento do beneficio social total (BST).

A área $Y\left(\mathrm{~A}_{0} \mathrm{M}_{0} \mathrm{~B}_{1} \mathrm{~A}_{1} \mathrm{~A}_{0}\right)$ pode ser derivada da seguinte forma (veja Figura 2A): toma-se a área do retângulo $\left(\mathrm{R}=X_{1}+\mathrm{Y}+X_{2}\right)=\mathrm{A}_{1} \mathrm{P}_{0} \mathrm{M}_{0} \mathrm{~N}$ e subtrai desta as duas áreas dos triângulos $\left(X_{1}\right.$ e $\left.X_{2}\right)$, respectivamente, $X_{I}=\mathrm{A}_{0} \mathrm{P}_{0} \mathrm{M}_{0}$ e $X_{2}=\mathrm{A}_{1} \mathrm{~B}_{1} \mathrm{~N}$.

Sendo:

área do retângulo: $R=Q_{0}\left(P_{0}-A_{1}\right)$;

área do $1^{\circ}$ triângulo: $X_{1}=0.5 \mathrm{Q}_{0}\left(\mathrm{P}_{0}-\mathrm{A}_{0}\right)$;

área do $2^{0}$ triângulo: $X_{2}=0.5 \mathrm{Q}_{0}\left(\mathrm{~B}_{1}-\mathrm{A}_{1}\right)$;

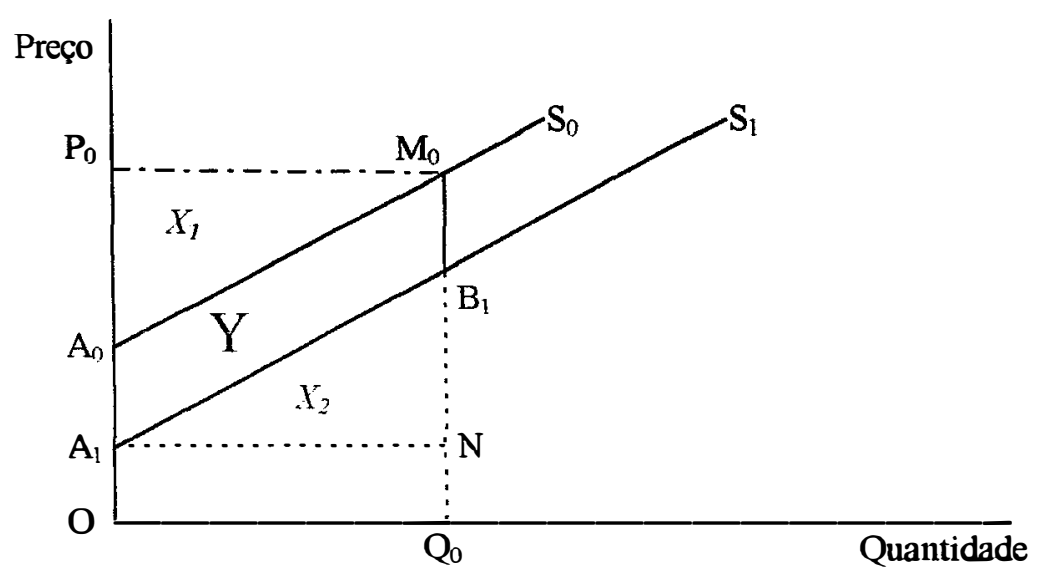

Figura 2A - Demonstração geométrica do cálculo da área $\mathrm{Y}$

Tem-se:

$Y=Q_{0}\left(P_{0}-A_{1}\right)-0,5 Q_{0}\left(P_{0}-A_{0}\right)-0,5 Q_{0}\left(B_{1}-A_{1}\right)$

Define-se o segmento $\bar{M}_{0} B_{1}$ como sendo $C$, onde $C=P_{0}-B_{1}$. Fazendo $B_{1}$ $=\mathrm{P}_{0}-\mathrm{C}$, substitui-se essa última expressão na equação acima obtendo: 


$$
\begin{aligned}
& Y=Q_{0}\left(P_{0}-A_{1}\right)-0,5 Q_{0}\left(P_{0}-A_{0}\right)-0,5 Q_{0}\left(P_{0}-C-A_{1}\right) \\
& Y=0,5 Q_{0}\left[2\left(P_{0}-A_{1}\right)-P_{0}+A_{0}-P_{0}+C+A_{1}\right] \\
& Y=0,5 Q_{0}\left(2 P_{0}-2 A_{1}-2 P_{0}+A_{0}+C+A_{1}\right] \\
& Y=0,5 Q_{0}\left(A_{0}+C-A_{1}\right)
\end{aligned}
$$

Sabendo que o segmento $\overline{\mathrm{M}_{0} \mathrm{~B}_{1}}$ também pode ser representado por $\mathrm{K} \cdot \mathrm{P}_{0}$ [como foi definido na expressão (5a) deste Apêndice], e que $C=\overline{\mathrm{M}_{0} \mathrm{~B}_{1}}$, tem-se:

$$
Y=0,5 Q_{0}\left(A_{0}+K \cdot P_{0}-A_{1}\right)
$$

Dessa forma, a área $\mathrm{Y}\left(\mathrm{A}_{0} \mathrm{M}_{0} \mathrm{~B}_{1} \mathrm{~A}_{1} \mathrm{~A}_{0}\right)$ é representada pela equação abaixo:

$$
Y=0,5 Q_{0}\left(K \cdot P_{0}+A_{0}-A_{1}\right)
$$

A área $\mathrm{X}$ pode ser representada pela área geométrica de um triângulo (ver Figura $3 \mathrm{~A}$ ), tomando o segmento $\overline{\mathrm{M}}_{0} \mathrm{~B}_{1}$ como a base do triângulo (que também pode ser representado por $\left.K \cdot P_{0}\right)$ e a distância $\left(Q_{1}-Q_{0}\right)$ como a altura do triângulo. Dessa forma, chega-se à expressão (7a):

$$
X=0,5 K \cdot P_{0}\left(Q_{1}-Q_{0}\right)
$$

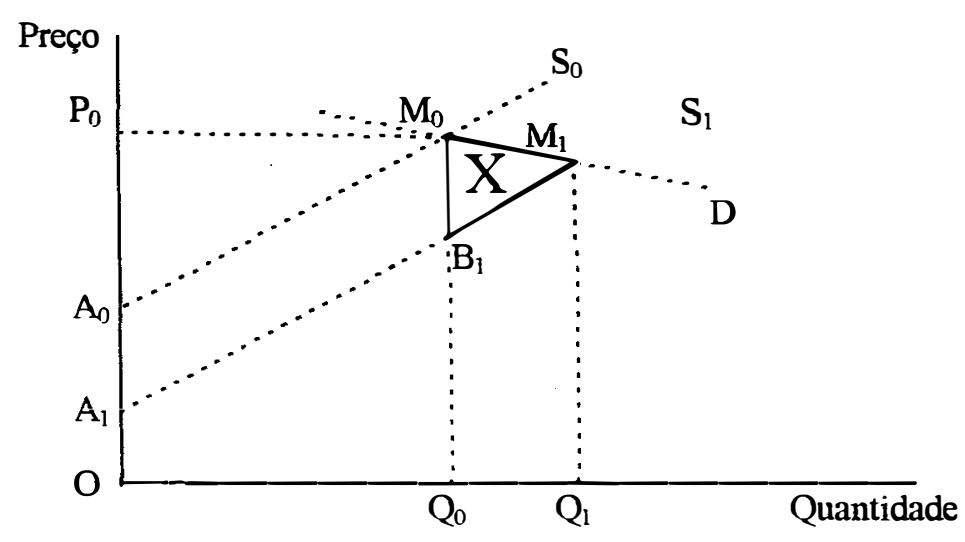

Figura 3A - Demonstração geométrica do cálculo da área X 
Caso do Deslocamento Paralelo da Curva de Oferta

Para um deslocamento paralelo da curva de oferta, a mudança da origem influencia a área $\mathrm{Y}\left(\mathrm{A}_{0} \mathrm{M}_{0} \mathrm{~B}_{1} \mathrm{~A}_{1} \mathrm{~A}_{0}\right)$. Seguindo as derivações acima, para uma mudança paralela, $\overline{A_{0} A_{l}}$ é igual a $K \cdot P_{0}$. Assim,

$$
A_{0}=A_{l}+K \cdot P_{0}
$$

Substituindo (8a) em (6a), tem-se a expressão (da parcela Y) do benefício social total (BST) para um deslocamento paralelo da curva de oferta, representado pela equação abaixo:

$$
\begin{aligned}
& Y=0,5 Q_{0}\left(K \cdot P_{0}+A_{1}+K \cdot P_{0}-A_{1}\right) \quad \text { ou } \\
& \text { Yparalelo }=K \cdot P_{0} Q_{0}
\end{aligned}
$$

Para encontrar o BST para um deslocamento paralelo, soma-se a expressão (7a) com a expressão (9a), obtendo:

$$
\text { BSTparalelo }=X+Y=0,5 K P_{0}\left(Q_{1}+Q_{0}\right)
$$

Caso do Deslocamento Pivotal da Curva de Oferta:

Para um deslocamento pivotal da curva de oferta, tem-se que:

$$
A_{0}=A_{1}
$$

Dessa forma, substituindo (1 la) em (6a), tem-se, para um deslocamento pivotal da curva de oferta:

$$
\begin{aligned}
& Y=0,5 Q_{0}\left(K \cdot P_{0}+A_{0}-A_{0}\right) \\
& Y \text { pivotal }=0,5 K P_{0} Q_{0}
\end{aligned}
$$


Assim, para encontrar o BST para um deslocamento pivotal da curva de oferta, soma-se a expressão (7a) com a expressão (12a), obtendo:

$$
\text { BSTpivotal }=X+\text { Ypivotal }=0,5 K \boldsymbol{P}_{0} Q_{1}
$$

Conforme cita Rose (1980), seguindo Pinstrup-Andersen et al. (1976) e Lindner \& Jarrett (1978), o ponto de equilíbrio após a inovação tecnológica $\left(M_{1}\right.$ na Figura 1A) pode ser encontrado pelas equações abaixo:

$$
\begin{aligned}
& \mathrm{P}_{1}=\mathrm{P}_{0}\left[1-\left(\mathrm{K} \varepsilon^{\mathrm{S}}\right) /\left(\varepsilon^{\mathrm{S}}+\varepsilon^{\mathrm{d}}\right)\right] \\
& \mathrm{Q}_{1}=\mathrm{Q}_{0}\left[1+\left(\mathrm{K} \varepsilon^{\mathrm{S}} \varepsilon^{\mathrm{d}}\right) /\left(\varepsilon^{\mathrm{S}}+\varepsilon^{\mathrm{d}}\right)\right]
\end{aligned}
$$

Substituindo a equação (15a) nas equações (10a) e (13a), e fazendo $\mathrm{Z}=\left(\mathrm{K} \varepsilon^{\mathrm{s}}\right) /\left(\varepsilon^{\mathrm{S}}+\varepsilon^{\mathrm{d}}\right)$, obtém-se as expressões abaixo, representando, respectivamente, o beneficio social total para uma mudança paralela e pivotal da curva de oferta:

BST $_{\text {paralelo }}=0,5 K P_{0} Q_{0}\left(2+Z \varepsilon^{d}\right)$

BST $_{\text {pivotal }}=0,5 K P_{0} Q_{0}\left(1+Z \varepsilon^{d}\right)$

onde:

$\mathrm{P}_{0}$ e $\mathrm{Q}_{0}=$ preço e a quantidade de equilíbrio, respectivamente, antes da inovação tecnológica;

$\varepsilon^{\mathrm{d}}=$ elasticidade-preço da demanda;

$\varepsilon^{\mathrm{S}}=$ elasticidade-preço da oferta;

$K=$ é o deslocador da curva de oferta e mede a mudança proporcional dos custos unitários 
As equações (16a) e (17a) também são válidas quando o deslocamento da curva de oferta é causado por um incentivo fiscal que reduza o custo de produção (que é o caso analisado na presente pesquisa).

Para estimar $K$ [ver a equação (4a)] é necessário ter uma estimativa do produto ofertado ao preço $\mathrm{P}_{0}$ antes e após a concessão de incentivos fiscais à pesca (isto é demonstrado no Apêndice C). 


\section{APÊNDICE B}

\section{ESTIMATIVAS DE EQUAÇÕES DE OFERTA E DEMANDA DO PESCADO NO BRASIL}

As equações de oferta e demanda de pescado, explicitadas no item 2.2 do capítulo 2, foram estimadas usando o método de mínimos quadrados em dois estágios e empregando o pacote estatístico RATS.

Inicialmente, utilizou-se os logaritmos dos valores da Tabela 8, obtendo-se o seguinte resultado:

$1^{\underline{a}}$ estimativa: equações originais

- Equação de demanda de pescado:

$$
\begin{gathered}
\mathrm{L} Q D_{t}=-47,1422-3,2364 \cdot \mathrm{L} P_{t}+0,0294 \cdot \mathrm{L} R_{t}+1,023 \cdot \mathrm{L} P B_{t}+3,5874 \cdot \mathrm{L} P O P_{t} \\
(-0,649)^{\mathrm{n} / \mathrm{s}} \quad(-0,6559)^{\mathrm{n} / \mathrm{s}}(0,0453)^{\mathrm{n} / \mathrm{s}} \quad(0,7663)^{\mathrm{n} / \mathrm{s}} \quad(0,7777)^{\mathrm{n} / \mathrm{s}} \\
R^{2}=0,13 \quad F=1,138^{\mathrm{n} / \mathrm{s}} \quad D W=1,29 \mathrm{c} / \mathrm{a}
\end{gathered}
$$

- Equação de oferta de pescado:

$$
\begin{aligned}
& L Q S_{t}= 19,9727+1,8823 \cdot \mathrm{L} P_{t}+0,0089 \cdot L I F_{t-k} \\
&(292,163)^{*} \quad(8,793)^{*} \quad(1,948)^{*} \\
& R^{2}=0,63 \quad F=27,639 * D W=1,29 \mathrm{c} / \mathrm{a}
\end{aligned}
$$

onde:

a) as variáveis são expressas em logaritmo neperiano (L); $-47,1422$ e 19,9727 são as constantes da equação de demanda e oferta, respectivamente; $P_{t}$ é o preço do pescado no momento t; $P B_{t}$ é o preço do boi gordo no momento t; $R_{t}$ representa a renda no momento t; $P O P_{t}$ é a população no momento $t ; I F_{t-k}$ é o volume de incentivos fiscais concedidos à atividade pesqueira no momento $\mathrm{t}-\mathrm{k}$ (onde $\mathrm{k}=0$ );

b) *: significativo a $1 \% ; * *$ : significativo a $11 \% ; \mathrm{n} / \mathrm{s}$ : não significativo; s/a: sem autocorrelação residual.

c) os números entre parênteses são as estatísticas t de student. 
Os itens a, b e c, apresentados acima, identificando as estruturas de demanda e oferta, bem como o grau de significância estatística dos coeficientes se aplicam às próximas estimativas apresentadas nesse Apêndice.

Ao observar que as estatísticas " $t$ " de Student, referentes a todas variáveis na equação de demanda, não foram estatisticamente significativas, decidiu-se estimar novamente o sistema de equações, retirando a variável população da estrutura de demanda. Os resultados da nova estimativa são listados a seguir:

$2^{\underline{a}}$ estimativa: Equações originais sem $L P O P_{t}$ na equação de demanda

- Equação de demanda de pescado:

$\mathrm{L} Q D_{t}=8,7676+0,4830 \cdot \mathrm{L} P_{t}+0,4341 \cdot \mathrm{L} R_{t}+0,007 \cdot \mathrm{L} P B_{t}$

$$
\begin{gathered}
(2,697)^{*}(1,2313)^{\mathrm{n} / \mathrm{s}}(3,4528)^{*} \quad(0,0836)^{\mathrm{n} / \mathrm{s}} \\
R^{2}=0,90 \quad F=99,605 * D W=0,92 \mathrm{c} / \mathrm{a}
\end{gathered}
$$

- Equação de oferta de pescado:

$$
\begin{aligned}
& L Q S_{t}= 19,9727+1,8823 \cdot \mathrm{L} P_{t}+0,0089 \cdot \mathrm{L} I F_{t-k} \\
&(292,163)^{*} \quad(8,793)^{*} \quad(1,948)^{*} \\
& R^{2}=0,63 \quad F=27,639 * D W=1,29 \mathrm{c} / \mathrm{a}
\end{aligned}
$$

Como na equação de demanda os coeficientes referentes ao preço do pescado $\left(P_{t}\right)$ e do preço da carne de boi $\left(P B_{t}\right)$ não foram significativos, e também o sinal do coeficiente $P_{t}$ foi contrário ao esperado, procedeu-se a uma nova estimativa substituindo a variável preço da carne de boi pela variável preço da carne de frango $\left(P F_{t}\right)$ na estrutura de demanda, reestimando essas equações. No caso da estrutura de oferta, essa foi mantida a mesma desde o início das estimativas. 
$3^{\underline{a}}$ estimativa: equações originais usando preço da carne de frango $\left(P F_{t}\right)$ na equação de demanda

- Equação de demanda de pescado:

$\mathrm{L} Q D_{t}=-75,9061-2,0708 \cdot \mathrm{L} P_{t}-0,1055 \cdot \mathrm{L} R_{t}+1,502 \cdot \mathrm{L} F_{t}+5,334 \cdot \mathrm{L} P O P_{t}$

$$
\begin{aligned}
& (-1,060)^{\mathrm{n} / \mathrm{s}}(-0,8706)^{\mathrm{n} / \mathrm{s}} \quad(-0,1960)^{\mathrm{n} / \mathrm{s}} \quad(1,1743)^{\mathrm{n} / \mathrm{s}} \quad(1,1884)^{\mathrm{n} / \mathrm{s}} \\
& R^{2}=0,52 \quad F=8,1708^{\mathrm{n} / \mathrm{s}} D W=1,38 \mathrm{~s} / \mathrm{a}
\end{aligned}
$$

- Equação de oferta de pescado:

$$
\begin{aligned}
L Q S_{t}= & 19,9727+1,8823 \cdot \mathrm{L} P_{t}+0,0089 \cdot L I F_{t-k} \\
& (292,163)^{*} \quad(8,793)^{*} \quad(1,948)^{*} \\
& R^{2}=0,63 \quad F=27,639 * D W=1,29 \mathrm{c} / \mathrm{a}
\end{aligned}
$$

Observa-se que as estatísticas " $t$ " de Student, referentes a todas variáveis na equação de demanda, não foram significativas, bem como o sinal do coeficiente da variável renda não foi o esperado. Dando seqüência, foi feita nova estimativa, retirando a variável população da estrutura de demanda, chegando ao seguinte resultado:

$4^{\mathrm{a}}$ estimativa: equações originais usando preço da carne de frango $\left(P F_{t}\right)$ e retirando a variável $L P O P_{t}$ na equação de demanda:

- Equação de demanda de pescado:

$\mathrm{L} Q D_{t}=8,7242+0,4831 \cdot \mathrm{L} P_{t}+0,4359 \cdot \mathrm{L} R_{t}+0,001 \cdot \mathrm{L} P F_{t}$

$$
\begin{gathered}
(2,698)^{*} \quad(1,0877)^{\mathrm{ns}} \quad(3,4881)^{*} \quad(0,0147)^{\mathrm{n} / \mathrm{s}} \\
R^{2}=0,90 \quad F=99,606 * D W=0,92 \mathrm{c} / \mathrm{a}
\end{gathered}
$$

- Equação de oferta de pescado:

$$
\begin{aligned}
& L Q S_{t}= 19,9727+1,8823 \cdot \mathrm{L} P_{t}+0,0089 \cdot \mathrm{L} / F_{t-k} \\
&(292,163)^{*} \quad(8,793)^{*} \quad(1,948)^{*} \\
& R^{2}=0,63 \quad F=27,639 * \quad D W=1,29 \mathrm{c} / \mathrm{a}
\end{aligned}
$$

A partir das estimativas acima, observou-se que não houve melhora dos resultados obtidos. Assim, decidiu-se estimar as equações de demanda e oferta do 
pescado usando valores per capita para as variáveis $Q D_{t}, Q S_{t}$, e $R_{t}$, seguindo o sistema de equações desenvolvido no item 2.2 do capítulo 2 desse estudo.

$5^{\mathbf{a}}$ estimativa: equações estimadas usando valores per capita para $Q D_{t}, Q S_{t}$, e $R_{t}$

- Equação de demanda de pescado:

$\mathrm{LQD} D_{t}=-2,0403-0,5640 \cdot \mathrm{L} P_{t}+0,3094 \cdot \mathrm{LPB} B_{t}+0,4628 \cdot \mathrm{L} R_{t}$

$$
\begin{array}{cc}
(-2,028)^{*} & (-2,242)^{*} \quad(3,271)^{*} \quad(3,389)^{*} \\
R^{2}=0,69 & F=24,101^{*} \quad D W=0,75^{\mathrm{c} / \mathrm{a}}
\end{array}
$$

- Equação de oferta de pescado:

$$
\begin{aligned}
L Q S_{t}= & 1,6360+0,530 \cdot \mathrm{L} P_{t}+0,0135 \cdot \mathrm{L} I F_{t-k} \\
& (44,951)^{*} \quad(4,596)^{*} \quad(5,582)^{*} \\
& R^{2}=0,56 \quad F=20,588^{*} \quad D W=1,03^{\text {c/a }}
\end{aligned}
$$

Apesar dos resultados estatísticos terem melhorado significativamente, o teste de Durbin Watson indicou presença de autocorrelação residual na estimativa das equação de demanda e oferta. Diante disso, procedeu-se a nova estimativa com correção dos erros.

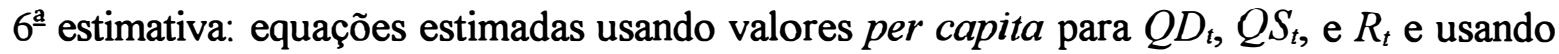
mecanismo de correção de erros

- Equação de demanda de pescado:

$\mathrm{LQD} D_{t}=-0,6682-0,4322 \cdot \mathrm{L} P_{t}+0,3705 \cdot L P B_{t}+0,2874 \cdot \mathrm{L} R_{t}$

$$
\begin{aligned}
& (-0,595)^{\mathrm{n} / \mathrm{s}}(-1,603)^{* *} \quad(4,072)^{*} \quad(1,938)^{*} \\
& R^{2}=0,8359 \quad F=50,9618^{*} \quad D W=2,2512^{\text {sia }}
\end{aligned}
$$

- Equação de oferta de pescado:

$$
\begin{aligned}
& \operatorname{LQS} S_{t}= 1,6856+0,4243 \cdot \mathrm{L} P_{t}+0,0113 \cdot \mathrm{L} I F_{t-k} \\
&(29,1136)^{*}(2,4699)^{*} \quad(3,4418)^{*} \\
& R^{2}=0,6822 \quad F=33,2834 * D W=1,9207^{\text {sa }}
\end{aligned}
$$


onde:

a) as variáveis são expressas em logaritmo neperiano (L); - 0,6682 e 1,6856 são as constantes da equação de demanda e oferta, respectivamente; $P_{t}$ é o preço do pescado no momento t; $P B_{t}$ é o preço do boi gordo no momento t; $R_{t}$ representa a renda per capita no momento t. $I F_{t-k}$ é o volume de incentivos fiscais concedidos à atividade pesqueira no momento $\mathrm{t}-\mathrm{k}$ (onde $\mathrm{k}=0$ );

b) *: significativo a $1 \%$; $* *$ : significativo a $11 \%$; $\mathrm{n} / \mathrm{s}$ : não significativo; s/a: sem autocorrelação residual.

c) os números entre parênteses são as estatísticas t de Student.

Esse novo modelo foi utilizado no capítulo 4 desse estudo para calcular os beneficios sociais derivados do programa de concessão de incentivos fiscais à pesca no Brasil. 


\section{APÊNDICE C}

\section{PROCEDIMENTOS PARA SE CHEGAR AOS VALORES DOS BENEFÍCIOS SOCIAIS A PARTIR DA ESTRUTURA DE OFERTA DO PESCADO}

Através da equação abaixo, mede-se o deslocamento da curva de oferta de pescado, advindo dos incentivos fiscais.

$$
\mathrm{L} Q_{2 t}^{S}=1,6856+0,4243 \cdot \mathrm{L} P_{t}+0,0113 \cdot \mathrm{L} I F_{t-k}
$$

Sabendo que $\varepsilon^{\mathrm{d}}=0,4322$ e $\varepsilon^{\mathrm{S}}=0,4243$, e considerando o ano de 1966 como sendo o período zero, tem-se que $P_{0(1966)}=0,85$ e $Q_{0(1966)}=5,59$.

Para calcular $Q_{2 t}^{S}$ de 1967 a 1986, basta substituir na equação (1c) os dados referentes a cada variável, respectivamente, nos respectivos anos, mantendo o mesmo preço a cada ano, ou seja, $P_{(1966)}=0,85$.

Supondo como exemplo o cálculo de $Q_{2(t=1967)}^{S}$ :

$$
\mathrm{L} Q_{2(t=1967)}^{S}=1,6856+0,4243 \cdot \mathrm{L} P_{0(1966)}+0,0113 \cdot \mathrm{L} I F_{1967}
$$

De posse de $\mathrm{L} Q_{2(t=1967),}^{S}$ extrai-se o antilog para se obter $Q_{2 t}^{S}$ para o ano de 1967. 
Com o valor de $Q_{2(t=1967),}^{S}$ pode-se calcular $K$ para 1967 da seguinte forma:

$$
K=\frac{\left(1-\frac{Q_{0(1966)}}{Q_{2(t=1967)}^{s}}\right)}{\varepsilon^{s}}
$$

Agora, é só substituir o valor de $K_{(1967)}$ na expressão abaixo, e calcular $Z$ para 1967, como segue:

$$
Z=\frac{K \varepsilon^{s}}{\left(\varepsilon^{s}+\varepsilon^{d}\right)}
$$

Com os valores de $K_{(1967)}$ e $Z_{(1967)}$, com a elasticidade preço da demanda $\varepsilon^{d}$ $=0,4322$, com $P_{0(1966)}=0,85$ e $Q_{0(1966)}=5,59$ (considerando o ano de 1966 como sendo o período zero), calcula-se o beneficio social per capita para 1967. Ou seja, com esses valores, o procedimento final é substituí-los na expressão para calcular o Beneficio Social Total (BST) para o ano de 1967, como segue abaixo:

Admitindo um deslocamento paralelo:

$$
B S T_{1967}^{\text {per capita }}(\text { paralelo })=0,5 K_{1967} P_{0(1966)} Q_{0(1966)}\left(2+Z_{1967} \varepsilon^{d}\right)
$$

Admitindo um deslocamento pivotal da curva de oferta:

$$
B S T^{\text {per capita }}{ }_{1967}(\text { pivotal })=0,5 K_{1967} P_{0(1966)} Q_{0(1966)}\left(1+Z_{1967} \varepsilon^{d}\right)
$$

Para obter o Beneficio Social Total (BST) mensurado em R $\$$ de agosto de 1994, basta multiplicar os valores de BST ${ }_{1967}^{\text {per capita }}$ pela população residente em 1967 $\left(P O P_{1967)}\right.$, como segue:

Admitindo um deslocamento paralelo:

$$
B S T_{1967}=B S T^{\text {per capita }}{ }_{1967} \text { (paralelo) } \cdot P O P_{1967}
$$

Admitindo um deslocamento pivotal da curva de oferta:

$$
B S T_{1967}=B S T_{1967}^{\text {per capita }}{ }_{\text {pivotal) }} \cdot P O P_{1967}
$$

Exemplo do cálculo do BST para o ano de 1968 :

$$
\mathrm{L} \underline{Q}_{2(t=1968)}=1,6856+0,4243 \cdot \mathrm{L} P_{0(\mathrm{t}=1966)}+0,0113 \cdot \mathrm{LIF} F_{1968}
$$




$$
\begin{aligned}
& \text { antilog } L Q_{2(t=1968)}^{S}=Q_{2(t=1968)}^{S} \\
& K_{1968}=\frac{\left(1-\frac{Q_{0(1966)}}{Q_{2(t=1968)}^{s}}\right)}{\varepsilon^{s}} ; \quad Z_{1968}=\frac{K_{1968} \varepsilon^{s}}{\left(\varepsilon^{s}+\varepsilon^{d}\right)} \cdot \\
& B S T^{\text {per capita }}{ }_{1968}\left(\text { paralelo) }=0,5 K_{1968} P_{0(1966)} Q_{0(1966)}\left(2+Z_{1968} \varepsilon^{d}\right) ;\right. \\
& B S T^{\text {per capita }}{ }_{1968}\left(\text { pivotal) }=0,5 K_{1968} P_{0(1966)} Q_{0(1966)}\left(1+Z_{1968} \varepsilon^{d}\right) ;\right. \\
& B S T_{1968}=B S T_{1968}^{\text {per capita }}\left(\text { paralelo) } \cdot P O P_{1968 ;}\right. \\
& B S T_{1968}=B S T_{1968}^{\text {per capita }}{ }_{196} \text { (pivotal) } \cdot P O P_{1968 .}
\end{aligned}
$$

O procedimento das equações (2c) a (8c) é repetido para os demais anos de 1969 a 1986, gerando os resultados colocados na Tabela 9 do capítulo 4.

Muitos autores que utilizaram o modelo beneficio-custo, com base nos conceitos de excedente econômico, adotaram o procedimento explicado acima. Nesse estudo, optou-se, também, por usar o procedimento acima descrito, pois o mesmo permite isolar os efeitos dos incentivos fiscais sobre o BST, sem incorrer em outros tipos de erros explicados a seguir.

\section{DIFERENTES MANEIRAS DE CALCULAR O BENEFÍCIO SOCIAL TOTAL}

Além do procedimento de considerar $P_{0}$ e $Q_{0}$ fixos (aos valores de 1966, ano anterior à concessão de incentivos fiscais à pesca), existem outras possibilidades de cálculo de BST:

1) Usando $P_{0}$ e $Q_{0}$ em equilibrio, estimados pelo modelo, para o cálculo do BST em todos os anos de vigência da política de incentivos fiscais à pesca

O procedimento é calcular, primeiramente, $P_{t}^{e}$ e $Q_{t}^{e}$ (preço e quantidade em equilíbrio, respectivamente) para os anos de 1966 a 1986, igualando as estruturas de oferta e demanda estimadas pelo modelo estabelecido nesse estudo (capítulo 4). 
O passo seguinte é calcular $\mathrm{L} Q^{S}{ }_{2 t}$, para os anos de 1967 a 1986, usando $P_{t-1}^{e}$ a cada momento t.

Com os dados anuais calculados para $\mathrm{L} Q_{2 t}^{S}(\mathrm{t}=1967 \ldots 1986)$, e utilizando $Q_{t-l}^{e}$, calcula-se o valor de $K_{t}$ para cada ano.

Após esses cálculos, substitu-se os valores nas equações para calcular o Beneficio Social Total (BST), considerando um deslocamento paralelo e pivotal da curva de oferta. $\mathrm{O}$ procedimento dessa forma de cálculo é: primeiramente, sendo o modelo

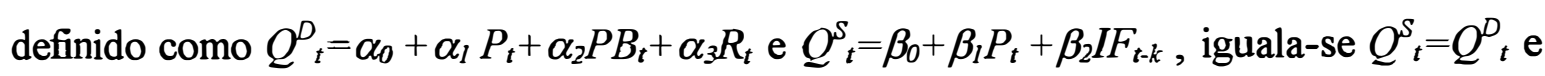
encontra-se $P_{t}^{e}$ e após isso encontra-se $Q_{t}^{e}$. Dessa forma, tem-se esses valores de $P_{t}^{e}$ e $Q^{e}{ }_{t}$ para os anos de 1966 a 1986. Assim sendo, segue-se os próximos passos.

- exemplo do cálculo do BST para os anos de 1967:

$$
\begin{aligned}
& \mathrm{L} Q_{2(t=1967)}^{S}=1,6856+0,4243 \cdot \mathrm{L} P^{e}{ }_{0(1966)}+0,01113 \cdot L I F_{1967} \\
& \operatorname{antilog} \mathrm{L} Q_{2(t=1967)}^{S}=Q_{2(t=1967)}^{S} \\
& K_{1967}=\frac{\left(1-\frac{Q_{0(1966)}^{e}}{Q_{2(t=1967)}^{s}}\right)}{\varepsilon^{s}} ; Z_{1967}=\frac{K_{1967} \varepsilon^{s}}{\left(\varepsilon^{s}+\varepsilon^{d}\right)} \text {. } \\
& \mathrm{BST}^{\text {per capita }}{ }_{1967}(\text { paralelo })=0,5 \mathrm{~K}_{1967} \mathrm{P}_{0(1966)}^{\mathrm{e}} \mathrm{Q}_{0(1966)}^{\mathrm{e}}\left(2+\mathrm{Z}_{1967} \varepsilon^{\mathrm{d}}\right) \text {; } \\
& \mathrm{BST}^{\text {per capita }}{ }_{1967}(\text { pivotal })=0,5 \mathrm{~K}_{1967} \mathrm{P}_{0(1966)}^{\mathrm{e}} \mathrm{Q}_{0(1966)}^{\mathrm{e}}\left(1+\mathrm{Z}_{1967} \varepsilon^{\mathrm{d}}\right) \text {; } \\
& \mathrm{BST}_{1967}=\mathrm{BST}^{\text {per capita }}{ }_{1967}(\text { paralelo }) \cdot \mathrm{POP}_{1967} \text {; } \\
& \mathrm{BST}_{1967}=\mathrm{BST}_{1967}^{\text {per capita }} \text { (pivotal) } \cdot \mathrm{POP}_{1967 .}
\end{aligned}
$$

- exemplo do cálculo do BST para o ano de 1968:

$$
\mathrm{L} Q_{2(t=1968)}^{S}=1,6856+0,4243 \cdot \mathrm{L} P^{e}{ }_{0(t=1967)}+0,0113 \cdot \mathrm{L} I F_{1968}
$$

antilog $\mathrm{L} Q_{2(t=1968)}^{S}=Q_{2(t=1968)}^{S}$

$$
K_{1968}=\frac{\left(1-\frac{Q^{e}{ }_{0(1967)}}{Q_{2(t=1968)}^{s}}\right)}{\varepsilon^{s}} ; Z_{1968}=\frac{K_{1968} \varepsilon^{s}}{\left(\varepsilon^{s}+\varepsilon^{d}\right)} .
$$




$$
\begin{aligned}
& \mathrm{BST}_{1968}^{\text {per capita }}(\text { paralelo })=0,5 \mathrm{~K}_{1968} \mathrm{P}_{0(1967)}^{\mathrm{e}} \mathrm{Q}_{0(1967)}^{\mathrm{e}}\left(2+\mathrm{Z}_{1968} \varepsilon^{\mathrm{d}}\right) ; \\
& \mathrm{BST}^{\text {per capita }}{ }_{1968}(\text { pivotal })=0,5 \mathrm{~K}_{1968} \mathrm{P}_{0(1967)}^{\mathrm{e}} \mathrm{Q}_{0(1967)}^{\mathrm{e}}\left(1+\mathrm{Z}_{1968} \varepsilon^{\mathrm{d}}\right) ; \\
& \mathrm{BST}_{1968}=\mathrm{BST}^{\text {per capita }}{ }_{1968}(\text { paralelo }) \cdot \mathrm{POP}_{1968 ;} \\
& \mathrm{BST}_{1968}=\mathrm{BST}^{\text {per capita }}{ }_{1968}(\text { pivotal }) \cdot \mathrm{POP}_{1968 .}
\end{aligned}
$$

Ao utilizar $P_{t}^{e}$ e $Q_{t}^{e}$ estimados pelas estruturas de oferta e demanda do modelo definido, incorre-se no erro estatístico incorporado tanto na estrutura de oferta como na estrutura de demanda de pescado.

2) Usando $P_{0}$ observado e $\underline{Q}_{0}$ estimado pelo modelo em 1966, ano anterior à política de incentivos fiscais à pesca, como dados fixos durante o cálculo do Benefício Social Total para todos os anos

O procedimento é calcular, primeiramente, $Q_{0\{t=1966)}^{e}$ (quantidade estimada pelo modelo em 1966), usando a estrutura de oferta definida no capítulo 4 deste estudo.

O próximo procedimento é calcular $\mathrm{L} Q_{2 t}^{S}(\operatorname{com~t}=1967$ a 1986), usando $P_{0}$ observado (preço antes da concessão dos incentivos fiscais à pesca) como fixo, a cada momento t. Ao fixar $P_{0}$ em 1966 como referência, está sendo isolado o efeito do fenômeno estudado, uma vez que, ano a ano, a variável incentivo fiscal é modificada, deslocando a curva de oferta de pescado.

Com os dados anuais calculados para $\mathrm{L}_{2 t}{ }_{2 t}(\mathrm{t}=1967 \ldots 1986)$, e utilizando $Q^{e}{ }_{0(t=1966)}$, calcula-se o valor de $\mathrm{K}$ para cada ano. Observa-se que, como nesse procedimento, está sendo utilizada a variável $Q_{0}^{e}$ (estimada). Assim, essa forma de cálculo incorpora um erro estatístico.

Com esses cálculos, substitui-se os valores nas equações para calcular o Beneficio Social Total (BST), considerando um deslocamento paralelo e pivotal da curva de oferta. $\mathrm{O}$ procedimento dessa forma de cálculo é: num primeiro momento, calcula-se $Q^{e}{ }_{0(t=1966)}$ substituindo os valores respectivos ao ano de 1966 na expressão da equação de oferta de pescado, $Q_{t}^{S}=\beta_{0}+\beta_{1} P_{0(1966)}+\beta_{2} I F_{1966}$. Sendo zero o valor de $\mathbb{I F}_{1966}$, a expressão fica: $Q^{S}{ }_{t}=\beta_{0}+\beta_{1} P_{0(1966)}$. 
- exemplo do cálculo do BST para o ano de 1967:

$\mathrm{L} Q_{2(t=1967)}^{S}=1,6856+0,4243 \cdot \mathrm{L} P_{0(\mathrm{t}=1966)}+0,0113 \cdot \mathrm{L} I F_{1967}$ $\operatorname{antilog} \mathrm{L} Q_{2(t=1967)}^{S}=Q_{2(t=1967)}^{S}$

$K_{1967}=\frac{\left(1-\frac{Q^{e}{ }_{0(1966)}}{Q_{2(t=1967)}^{s}}\right)}{\varepsilon^{s}} ; Z_{1967}=\frac{K_{1967} \varepsilon^{s}}{\left(\varepsilon^{s}+\varepsilon^{d}\right)}$.

$\mathrm{BST}^{\text {per capita }}{ }_{1967}($ paralelo $)=0,5 \mathrm{~K}_{1967} \mathrm{P}_{0(1966)} \mathrm{Q}_{0(1966)}^{\mathrm{e}}\left(2+\mathrm{Z}_{1967} \varepsilon^{\mathrm{d}}\right)$;

$\mathrm{BST}^{\text {per capita }}{ }_{1967}($ pivotal $)=0,5 \mathrm{~K}_{1967} \mathrm{P}_{0(1966)} \mathrm{Q}_{0(1966)}^{\mathrm{e}}\left(1+\mathrm{Z}_{1967} \varepsilon^{\mathrm{d}}\right)$;

$\mathrm{BST}_{1967}=\mathrm{BST}^{\text {per capita }}{ }_{1967}($ paralelo $) \cdot \mathrm{POP}_{1967}$;

$\mathrm{BST}_{1967}=\mathrm{BST}^{\text {per capita }}{ }_{1967}$ (pivotal) $\cdot$ POP $_{1967}$

- exemplo do cálculo do BST para o ano de 1968:

$\mathrm{L} Q_{2(t=1968)}^{S}=1,6856+0,4243 \cdot \mathrm{L} P_{0(\mathrm{t}=1966)}+0,0113 \cdot \mathrm{L} I F_{1968}$

antilog $\mathrm{L} Q_{2(t=1968)}^{S}=Q_{2(t=1968)}^{S}$

$$
K_{1968}=\frac{\left(1-\frac{Q^{e}{ }_{0(1966)}}{Q_{2(t=1968)}^{s}}\right)}{\varepsilon^{s}} ; Z_{1968}=\frac{K_{1968} \varepsilon^{s}}{\left(\varepsilon^{s}+\varepsilon^{d}\right)} .
$$

$\mathrm{BST}^{\text {per capita }}{ }_{1968}($ paralelo $)=0,5 \mathrm{~K}_{1968} \mathrm{P}_{0(1966)} \mathrm{Q}_{0(1966)}^{\mathrm{e}}\left(2+Z_{1968} \varepsilon^{\mathrm{d}}\right)$;

$\mathrm{BST}^{\text {per capita }}{ }_{1968}($ pivotal $)=0,5 \mathrm{~K}_{1968} \mathrm{P}_{0(1966)} \mathrm{Q}_{0(1966)}^{\mathrm{e}}\left(1+\mathrm{Z}_{1968} \varepsilon^{\mathrm{d}}\right)$;

$\mathrm{BST}_{1968}=\mathrm{BST}^{\text {per capita }}{ }_{1968}$ (paralelo) $\cdot \mathrm{POP}_{1968 ;}$

$\mathrm{BST}_{1968}=\mathrm{BST}_{1968}^{\text {per capita }}$ (pivotal) $\cdot \mathrm{POP}_{1968}$.

3) Usando $P_{t-1}$ e $Q_{t-1}$ observados, a cada momento t, para calcular o $B S T_{t}$

O procedimento é calcular $\mathrm{L} Q^{S}{ }_{2 t}\left(\operatorname{com~t}=1967\right.$ a 1986), usando $P_{O(t-1)}$ (preço antes da concessão dos incentivos fiscais à pesca), a cada momento $t$.

Com os dados anuais calculados para $\mathrm{L}^{S}{ }_{2 t}(\mathrm{t}=1967 \ldots 1986)$, calcula-se o valor de $\mathrm{K}_{\mathrm{t}}$ para cada ano. 
Com esses cálculos, substitui-se os valores nas equações para calcular o Beneficio Social Total (BST), considerando um deslocamento paralelo e pivotal da curva de oferta. Nesse caso, ao calcular $\mathrm{L} Q_{2 t}^{S}, K$ e $Z$, utilizam-se os valores observados de $P$ e $Q$ no momento $t-1$. Observe alguns exemplos:

- exemplo do cálculo do BST para os anos de 1967:

$\mathrm{L} Q_{2(t=1967)}^{S}=1,6856+0,4243 \cdot \mathrm{L} P_{0(\mathrm{t}=1966)}+0,0113 \cdot \mathrm{LIF} F_{1967}$ antilog $\mathrm{L} Q_{2(t=1967)}^{S}=Q_{2(t=1967)}^{S}$ $K_{1967}=\frac{\left(1-\frac{Q_{0(1966)}}{Q_{2(t=1967)}^{s}}\right)}{\varepsilon^{s}} ; Z_{1967}=\frac{K_{1967} \varepsilon^{s}}{\left(\varepsilon^{s}+\varepsilon^{d}\right)}$.

$\mathrm{BST}^{\text {per capita }}{ }_{1967}($ paralelo $)=0,5 \mathrm{~K}_{1967} \mathrm{P}_{0(1966)} \mathrm{Q}_{0(1966)}\left(2+Z_{1967} \varepsilon^{\mathrm{d}}\right)$; $\mathrm{BST}^{\text {per capita }}{ }_{1967}($ pivotal $)=0,5 \mathrm{~K}_{1967} \mathrm{P}_{\mathbf{0 ( 1 9 6 6 )}} \mathrm{Q}_{0(1966)}\left(1+Z_{1967} \varepsilon^{\mathrm{d}}\right)$;

$\mathrm{BST}_{1967}=\mathrm{BST}^{\text {per capita }}{ }_{1967}$ (paralelo) $\cdot \mathrm{POP}_{1967}$;

$\mathrm{BST}_{1967}=\mathrm{BST}^{\text {per capita }}{ }_{1967}$ (pivotal) $\cdot \mathrm{POP}_{1967}$.

- exemplo do cálculo do BST para o ano de 1968:

$\mathrm{L} Q_{2(t=1968)}^{S}=1,6856+0,4243 \cdot \mathrm{L} P_{O_{(\mathrm{t}=1967)}}+0,0113 \cdot \mathrm{LIF}_{1968}$ $\operatorname{antilog} \mathrm{L} Q_{2(t=1968)}^{S}=Q_{2(t=1968)}^{S}$ $K_{1968}=\frac{\left(1-\frac{Q_{0(1967)}}{Q_{2(t=1968)}^{s}}\right)}{\varepsilon^{s}} ; Z_{1968}=\frac{K_{1968} \varepsilon^{s}}{\left(\varepsilon^{s}+\varepsilon^{d}\right)}$. $\mathrm{BST}^{\text {per capita }}{ }_{1968}($ paralelo $)=0,5 \mathrm{~K}_{1968} \mathrm{P}_{\mathrm{O}_{(1967)}} \mathrm{Q}_{0(1967)}\left(2+\mathrm{Z}_{1968} \varepsilon^{\mathrm{d}}\right)$; $\mathrm{BST}^{\text {per capita }}{ }_{1968}($ pivotal $)=0,5 \mathrm{~K}_{1968} \mathrm{P}_{0(1967)} \mathrm{Q}_{0(1967)}\left(1+Z_{1968} \varepsilon^{\mathrm{d}}\right)$; $\mathrm{BST}_{1968}=\mathrm{BST}^{\text {per capita }}{ }_{1968}($ paralelo $) \cdot \mathrm{POP}_{1968}$; $\mathrm{BST}_{1968}=\mathrm{BST}^{\text {per capita }}{ }_{1968}($ pivotal $) \cdot \mathrm{POP}_{1968}$.

Nesse tipo de cálculo não se consegue isolar os efeitos dos incentivos fiscais, pois os valores observados de $P_{t-1}$ e $Q_{t-1}$ também incluem os impactos da sobrepesca de certas espécies, além de outros possíveis efeitos. 
4) Calculando uma área média de BST durante a concessão de incentivos fiscais à pesca

O primeiro passo é determinar a média dos preços e quantidades nos anos anteriores ao início dos incentivos fiscais à pesca. Por exemplo, de 1960 a 1966, obtendo $P_{0(60 / 6))}$ e $Q_{0(60 / 66) \text {. }}$

De posse desses dados, é necessário encontrar também a média de incentivos fiscais para o período de 1967 a 1986 ( $\left(F_{67 / 86}\right)$, para então determinar $\mathrm{L} Q_{2 t(67 / 86)}^{S}$ da seguinte forma:

$$
\mathrm{L} Q_{2(1967 / 1986)}=1,6856+0,4243 \cdot \mathrm{L} P_{o(1960 / 1966)}+0,0113 \cdot \mathrm{L} I F_{l 967}
$$

Com a quantidade média calculada para $\mathrm{L} Q_{2 t}^{S}(1967 / 1986)$, calcula-se o valor de $\mathrm{K}_{67 / 86}$ e $Z_{67 / 86}$ para o período de vigência dos incentivos fiscais:

$$
K_{1967 / 1986}=\frac{\left(1-\frac{Q_{(1960 / 1966)}}{Q_{2(1967 / 1986)}^{s}}\right)}{\varepsilon^{s}} ; \quad Z_{1967 / 1986}=\frac{K_{1967 / 1986} \varepsilon^{s}}{\left(\varepsilon^{s}+\varepsilon^{d}\right)}
$$

Com esses cálculos, substitui-se os valores nas equações para calcular o Beneficio Social Total (BST), considerando um deslocamento paralelo e pivotal da curva de oferta:

$$
\begin{aligned}
& \mathrm{BST}^{\text {per capita }}{ }_{1967 / 1986}(\text { paralelo })=0,5 \mathrm{~K}_{1967 / 1986} \mathrm{P}_{0(1960 / 1966)} \mathrm{Q}_{0(1960 / 1966)}\left(2+\mathrm{Z}_{1967 / 1986} \varepsilon^{\mathrm{d}}\right) ; \\
& \mathrm{BST}^{\text {per capita }}{ }_{1967 / 1986}(\text { pivotal })=0,5 \mathrm{~K}_{1967 / 1986} \mathrm{P}_{0(1960 / 1966)} \mathrm{Q}_{0(1960 / 1966)}\left(1+\mathrm{Z}_{1967 / 1986} \varepsilon^{\mathrm{d}}\right) ; \\
& \mathrm{BST}_{1967 / 1986}=\mathrm{BST}^{\text {per capita }}{ }_{1967 / 1986}(\text { paralelo }) \cdot \mathrm{POP}_{1968 ;} \\
& \mathrm{BST}_{1967 / 1986}=\mathrm{BST}^{\text {per capita }}{ }_{1967 / 1986}(\text { pivotal }) \cdot \mathrm{POP}_{1968 .} .
\end{aligned}
$$

No caso acima, há a arbitrariedade da escolha de que periodo de tempo antes dos incentivos fiscais deverá ser escolhido. Isto é, que período de tempo será considerado para calcular $P_{0}$ e $Q_{0}$ ? 